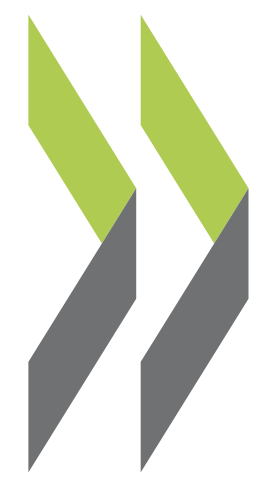

OECD Economics Department Working Papers No. 1203

Efficiency and Contestability in the Colombian Banking System

Christian Daude, Julien Pascal 


\section{Unclassified}

ECO/WKP(2015)21

Organisation de Coopération et de Développement Économiques

Organisation for Economic Co-operation and Development

15-Apr-2015

ECONOMICS DEPARTMENT

English - Or. English

\section{EFFICIENCY AND CONTESTABILITY IN THE COLOMBIAN BANKING SYSTEM}

ECONOMICS DEPARTMENT WORKING PAPERS No. 1203

By Christian Daude and Julien Pascal

OECD Working Papers should not be reported as representing the official views of the OECD or of its member countries. The opinions expressed and arguments employed are those of the author(s).

Authorised for publication by Alvaro Pereira, Director, Country Studies Branch, Economics Department.

All Economics Department Working Papers are available at www.oecd.org/eco/workingpapers

JT03374483

Complete document available on OLIS in its original format

This document and any map included herein are without prejudice to the status of or sovereignty over any territory, to the delimitation of international frontiers and boundaries and to the name of any territory, city or area. 
OECD Working Papers should not be reported as representing the official views of the OECD or of its member countries. The opinions expressed and arguments employed are those of the author(s).

Working Papers describe preliminary results or research in progress by the author(s) and are published to stimulate discussion on a broad range of issues on which the OECD works.

Comments on Working Papers are welcomed, and may be sent to OECD Economics Department, 2 rue André-Pascal, 75775 Paris Cedex 16, France, or by e-mail to eco.contact@oecd.org

This document and any map included herein are without prejudice to the status of or sovereignty over any territory, to the delimitation of international frontiers and boundaries and to the name of any territory, city or area.

The statistical data for Israel are supplied by and under the responsibility of the relevant Israeli authorities. The use of such data by the OECD is without prejudice to the status of the Golan Heights, East Jerusalem and Israeli settlements in the West Bank under the terms of international law.

\section{(C) OECD (2015)}

You can copy, download or print OECD content for your own use, and you can include excerpts from OECD publications, databases and multimedia products in your own documents, presentations, blogs, websites and teaching materials, provided that suitable acknowledgment of OECD as source and copyright owner is given. All requests for commercial use and translation rights should be submitted to rights@oecd.org 


\section{ABSTRACT/RÉSUMÉ}

\section{Efficiency and Contestability in the Colombian Banking System}

Despite progress in the past decade, financial markets in Colombia remain relatively small and shallow. In particular the banking system suffers high intermediation costs, which limit constrains access to finance by households and firms. This paper explores some of the causes behind these intermediation costs. An accounting decomposition of the lending-deposit spread suggests that the levels of contestability and efficiency are low. A more in-depth analysis using stochastic frontier and data envelopment analyses confirm that the efficiency of the Colombian commercial banking system is low compared to other emerging markets and OECD economies with similar levels of development. Furthermore, econometric estimates of market contestability support the hypothesis that contestability in Colombia is subpar. Finally, the paper also explores some of the potential determinants of efficiency and contestability for a sample of the 24 countries over the period $2004-2013$.

This Working Paper relates to the 2014 OECD Economic Survey of Colombia. (www.oecd.org/eco/surveys/economic-survey-colombia.htm)

\section{JEL classification codes: D43, G21, G28}

Keywords: Banking system, efficiency, contestability, lending-deposit spread, stochastic frontier analysis, data envelopment analysis, Panzar-Rosse model

\footnotetext{
**************************************
}

\section{Efficience et contestabilité du marché bancaire en Colombie}

Malgré les progrès accomplis durant la décennie précédente, les marchés financiers colombiens demeurent peu développés. En particulier, le système bancaire affiche des coûts d'intermédiation élevés qui limitent l'accès financier des ménages et des entreprises. Ce papier explore quelques-uns des déterminants de ces coûts d'intermédiation. Une décomposition comptable de la différence entre les taux d'emprunt et les taux de prêt indique que l'efficience et la contestabilité sont limitées. Une étude approfondie reposant sur les méthodes de frontière stochastique et d'enveloppement des données confirme que l'efficience des banques commerciales colombiennes est faible comparée à d'autres pays émergents et à des pays de l'OCDE ayant le même niveau de développement. Par ailleurs, une estimation économétrique du degré de contestabilité du marché bancaire colombien révèle que celui-ci est bas. Finalement, les déterminants de l'efficience et de la contestabilité sont analysés pour un échantillon de 24 pays sur la période $2004-2013$.

Ce document de travail se rapporte à l'Étude économique 2014 de l'OCDE sur la Colombie (www.oecd.org/fr/eco/etudes/etude-economique-colombie.htm).

Classification JEL : D43, G21, G28

Mots clés : système bancaire, efficience, contestabilité, différence taux d'emprunt-taux de prêt, méthode de frontière stochastique, méthode d'enveloppement des données, modèle de Panzar-Rosse. 


\section{TABLE OF CONTENTS}

EFFICIENCY AND CONTESTABILITY IN THE COLOMBIAN BANKING SYSTEM .........................6

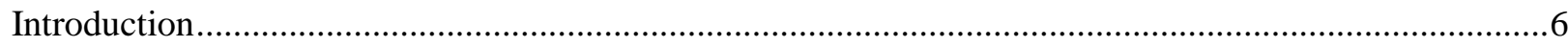

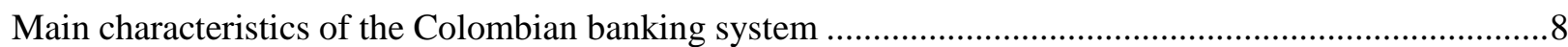

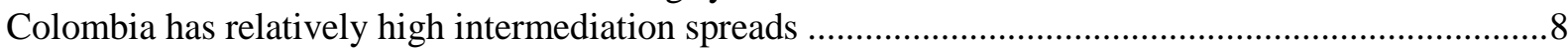

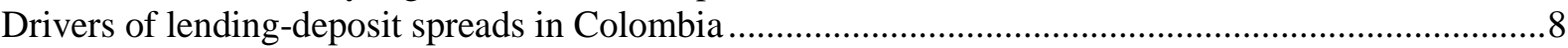

Increasing concentration with more private and foreign investments ................................................12

Cost efficiency of the Colombian banking system ................................................................................

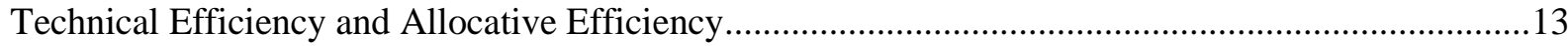

An international comparison based on stochastic frontier estimates...................................................14

Cost Efficiency Determinants: regulations and individual bank effects ............................................22

Competition and contestability in the Colombian banking market........................................................26

International comparison of banking sector competitiveness structures .............................................26

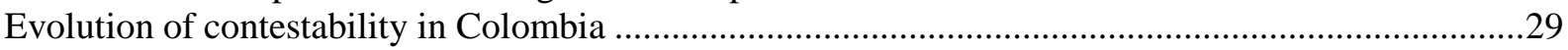

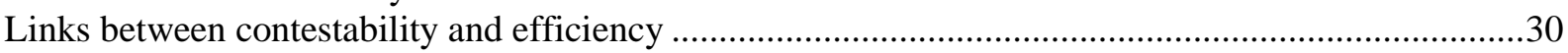

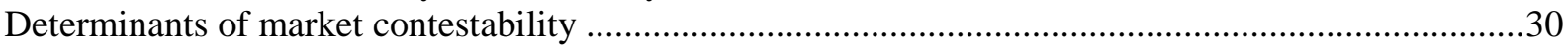

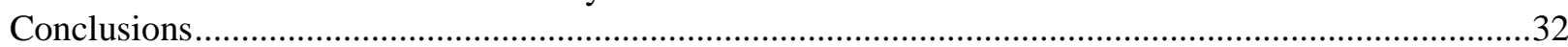

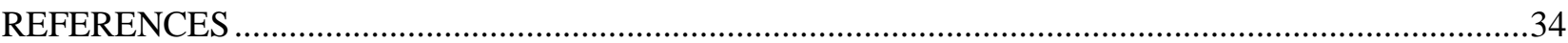

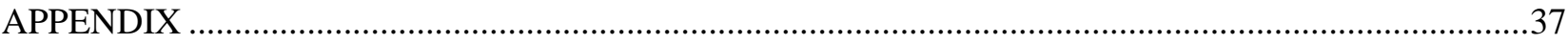

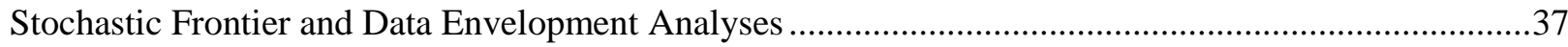

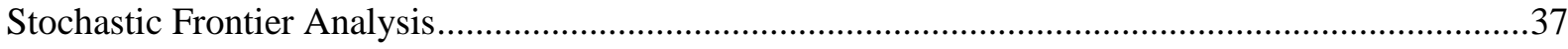

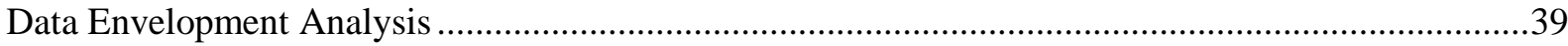

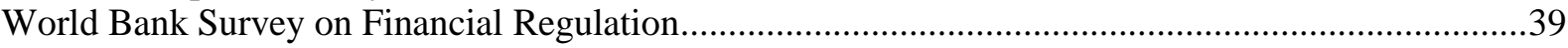

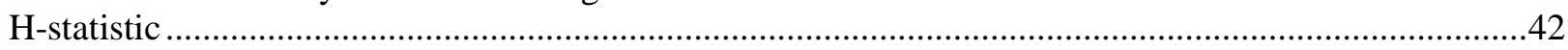

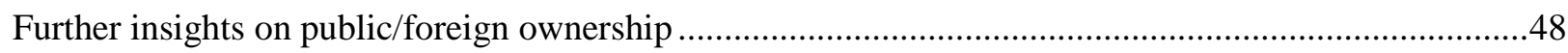

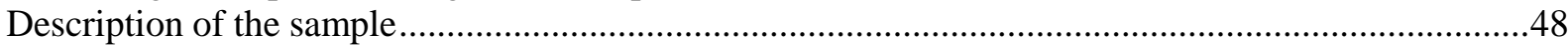

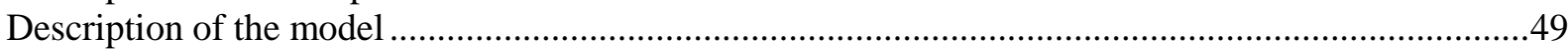

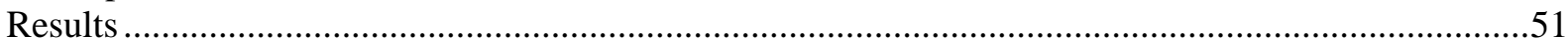

\section{Tables}

1. Implicit lending-deposit spread decomposition in Colombia, $2004-2013 \ldots \ldots \ldots \ldots \ldots \ldots \ldots \ldots \ldots \ldots . . . .11$

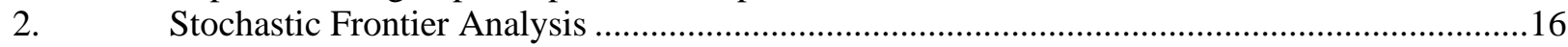

3. Joint estimation of the cost frontier and inefficiency determinants .......................................24

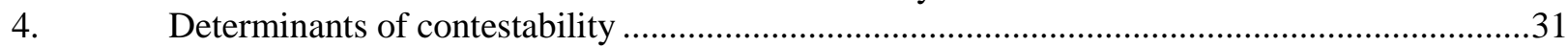

5. Impact of structural and regulative characteristic on efficiency and contestability ..................32

A.1. $\quad$ SFA - proxy 1 for labour price - number of banks by year ................................................37

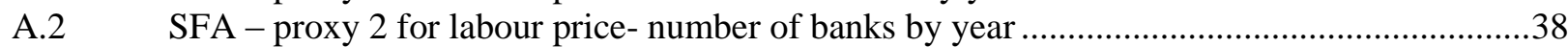

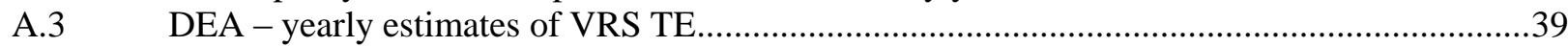

A.4. $\quad$ H-statistic, proxy 1 for labour price and control variables, main estimates ..............................42

A.5. H-statistic, proxy 1 for labour price and control variables, hypothesis testing .........................43

A.6. H-statistic, proxy 2 for price of labour and control variables, main estimates .........................44

A.7. H-statistic, proxy 2 for price of labour and control variables, hypothesis testing .....................45

A.8. H-statistic, proxy 1 for labour price without control variables................................................46

A.9. H-Statistic, proxy 2 for labour price without control variables .............................................47 


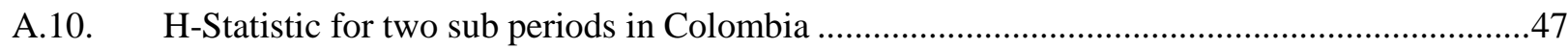

A.11. Parametric approach for a time-varying H-statistic in Colombia ............................................48

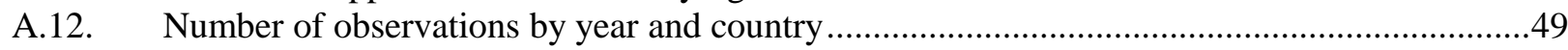

A.13. Joint estimation of the cost frontier and inefficiency determinants .........................................51

\section{Figures}

1. Financial access and depth in LAC, OECD and key emerging countries ...................................

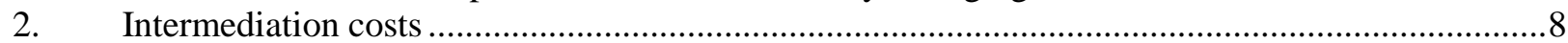

3. Bank lending-deposit spread decomposition in Colombia, $2004-2013$....................................10

4. Operational costs and profitability in Colombia, emerging and selected OECD countries in 201111

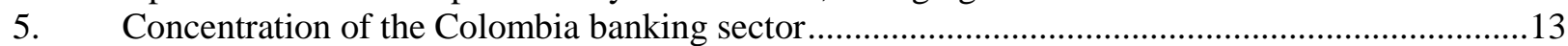

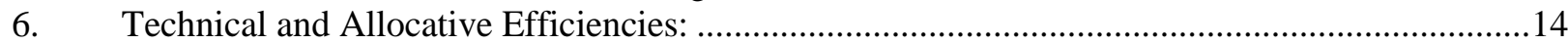

7. Stochastic frontier analysis, commercial banking sectors' average cost efficiency, $2004-2013 . .17$

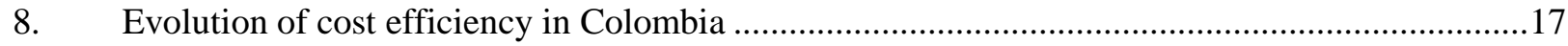

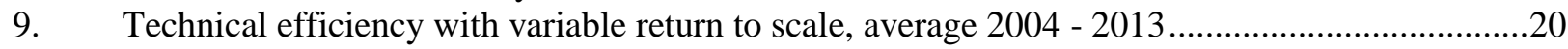

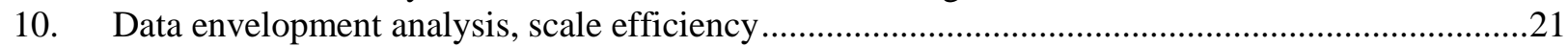

11. Evolution of regulative and structural characteristics of banking sectors....................................23

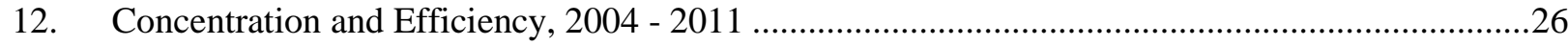

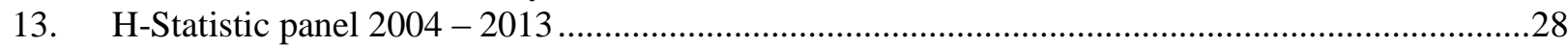

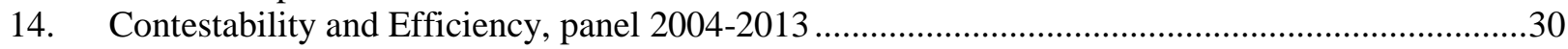

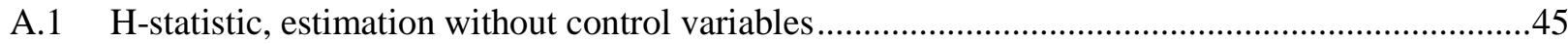

A.2. Stochastic frontier analysis, commercial banking sectors' average cost efficiency, $1999-2009 . .51$

\section{Boxes}

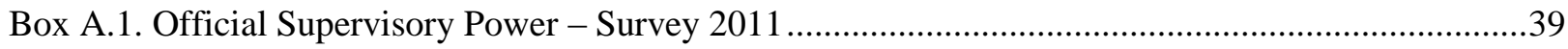

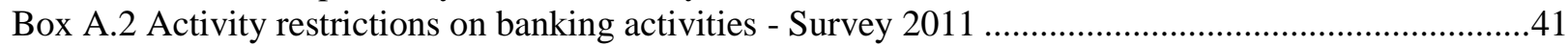




\title{
EFFICIENCY AND CONTESTABILITY IN THE COLOMBIAN BANKING SYSTEM
}

\author{
By Christian Daude and Julien Pascal ${ }^{1}$
}

\section{Introduction}

1. A growing body of evidence suggests that financial markets have a powerful effect on economic development (Demirguç-Kunt and Levine, 2008). By linking investors and savers, banks play a crucial role in the allocation of resources, diversifying risks and reducing information frictions in credit markets. Limited access to loans for individuals and firms hinders investment in human and physical capital, innovation and productivity growth. Besides long-run growth, the empirical evidence also shows that access to finance plays an important role in shaping economic disparities between individuals (Cihák et al., 2012). Restrictions to financial access reduce economic opportunities for those lacking of parental wealth, social status and political connections. Furthermore, a well-functioning financial system usually reduces the gap between the lower and the upper tail of the income distribution in developing and emerging market economies (Beck et al., 2007).

2. Despite recent progress, Colombia's financial markets are relatively small and shallow in several dimensions. Domestic credit to the private sector (as share of GDP) is currently at around 50\%, almost 15 percentage points above the peak in the late 1990s before the banking crisis of 1998-2000 (Figure 1, Panel A). However, it falls significantly below, for example, Chile (100\%) or the OECD average of around 120\% (Figure 1, Panel B), while many other Latin American and Caribbean (LAC) economies share. Even when taking into account the overall level of development - proxied by GDP per capita Colombia's financial markets are smaller than expected. For example, a simple logarithmic regression analysis on GDP per capita implies that Colombia's observed level of credit to the private sector is around 15 percentage points of GDP below its expected level (Figure 1, Panel C). Although not presented here, a similar analysis for stock and bond markets yield the same results. Financial access in Colombia is also subpar compared to many LAC and OECD economies. Only 30 percent of the population has an account at a formal financial institution (Figure 1, Panel D).

\footnotetext{
${ }^{1}$ Christian Daude works in the OECD Economics Department. At the time of writing this Working Paper, Julien Pascal was working in the OECD Economics Department. The paper was originally prepared for the OECD Economic Survey of Colombia published in January 2015 under the authority of the Economic and Development Review Committee. The authors are grateful to Andrés Fuentes, Eduardo Olaberría, Alvaro Pereira, Piritta Sorsa and all participants of an internal OECD seminar for their comments and suggestions on earlier drafts. Special thanks go to Guillaume Bousquet for statistical assistance and Ines Gómez Palacio and Anthony Bolton for general administrative support.
} 
Figure 1. Financial access and depth in LAC, OECD and key emerging countries

A. Domestic credit to private sector (\% of GDP) in Colombia, 1990 - 2013

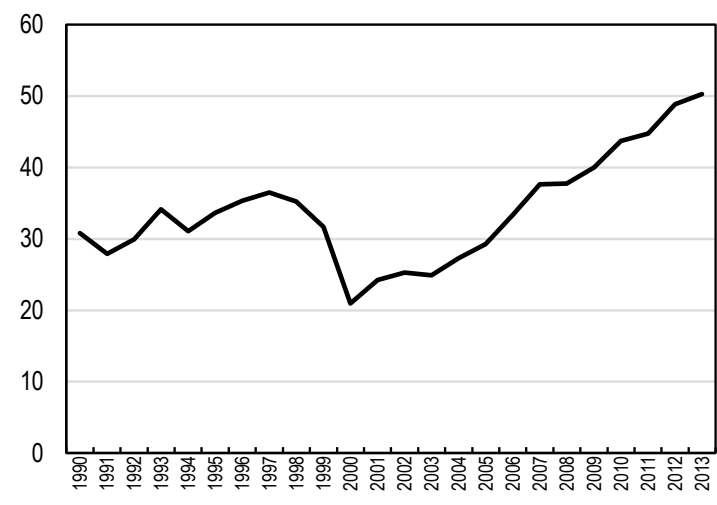

C. Domestic credit to private sector (\% of GDP) in LAC, OECD and key emerging countries in 2013

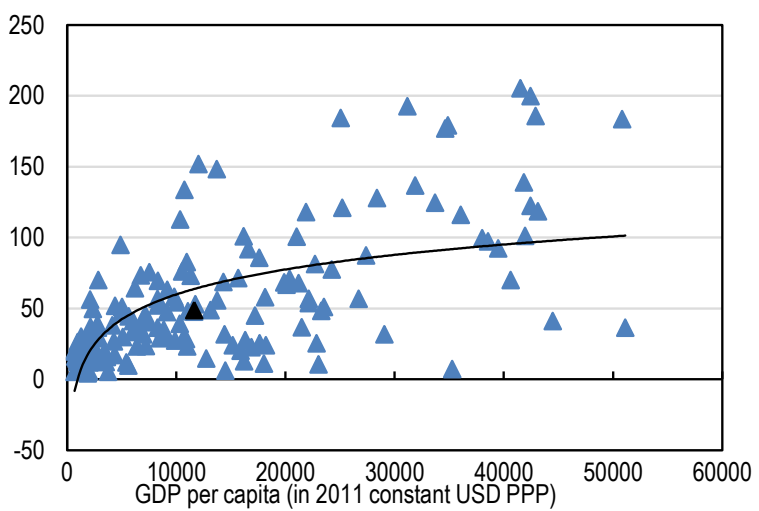

B. Domestic credit to private sector (\% of GDP) in LAC, OECD and key emerging countries in 2013

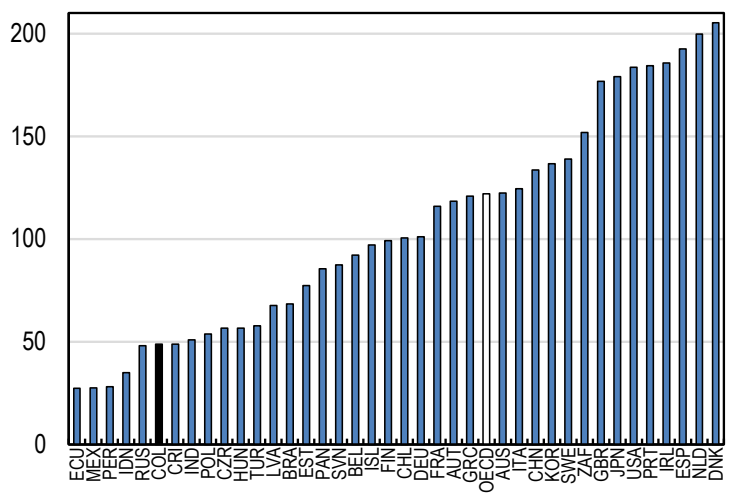

D. Percentage of the population (age 15+) with an account at a formal financial institution in 2011

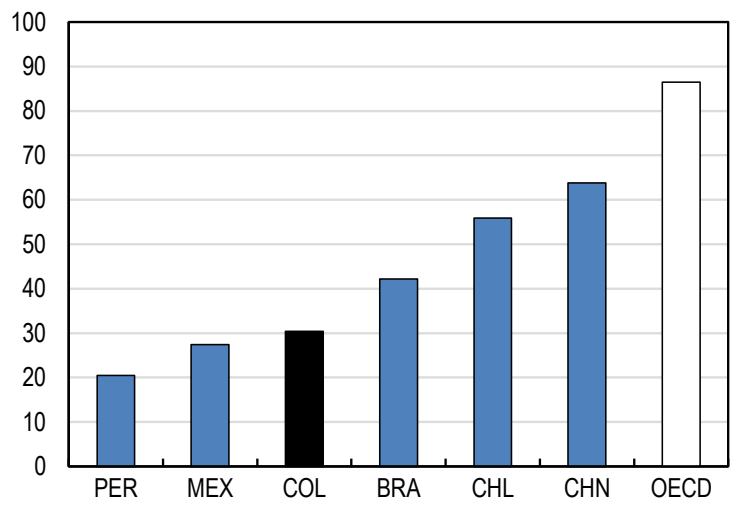

Source: World Bank, World Development Indicators Database and Global Financial Development Database

3. As documented in the following sections, the Colombian banking sector has become more concentrated, but also more open to private and foreign investment. At the same time, financial sector depth and access to credit seem to be limited by high intermediation costs, as shown by the significant bank lending-deposit spreads - defined as the difference between the interest rate charged on loans and the interest paid on deposits. In general, the literature shows that the associated high costs of finance tend to hold back investment and growth (Randal 1998, Beck et al., 2000). The following section explores the restrictions on Colombia's financial markets, as well as the driving forces of lending-deposit spreads using a simple accounting model.

4. Although in principle markets with low levels of contestability can be relatively efficient and stable, the two issues often go hand-in-hand. Contestability measures the degree to which barriers to entry and exit restrict new entries, such that contestable markets have limited barriers. This generally ensures a competitive behaviour by market participants. More contestability usually ensures a higher level of efficiency, defined as the ability of a firm to maximize its outputs given a certain set of inputs, as well as choosing the optimal scale of activities. The level and evolution of efficiency in Colombia, as well as its drivers, is explored in section 3, using stochastic and data envelopment analyses on a panel of commercial banks from 23 countries between 2004 and 2013. Section 4 evaluates the degree of contestability for the same sample. The last section explores the link between efficiency and contestability and summarizes the main findings. 


\section{Main characteristics of the Colombian banking system}

\section{Colombia has relatively high intermediation spreads}

5. Colombia exhibits a high lending-deposit spread by OECD standards. The lending-deposit spread - measured as the difference between the lending rate (the rate at which individuals or firms can borrow in the financial market) and the deposit rate (interest rate paid on deposits) - is significantly higher than the OECD average (Figure 2, Panel A). Although other LAC countries also present similar problems, good performers such as Chile or Mexico also exhibit lower interest spreads than Colombia. This high lending-deposit spread implies a higher cost for individuals and firms, limiting access and the size of the financial sector. Furthermore, despite fluctuations, it remained high over the last ten years (Figure 2, Panel B).

\section{Figure 2. Intermediation costs}

A. Bank lending-deposit spread (\%) in LAC, OECD and key emerging countries, 2011

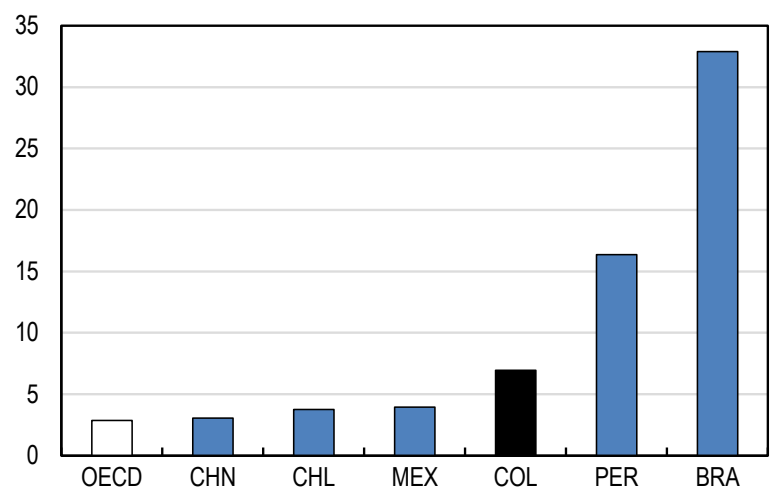

B. Bank lending-deposit spread (\%) in Colombia, $2004-2012$

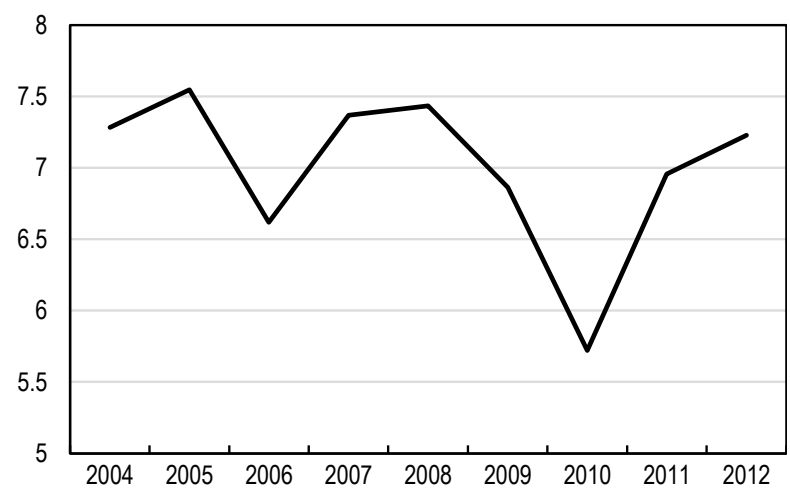

Note: 1 . bank lending-deposit spread is the difference between lending rate - the rate charged by banks on loans - and deposit rate the rate offered by commercial banks on three-month deposits

2. Because of missing values, the OECD average only includes Australia, Canada, Switzerland, Chile, Czech Republic, Estonia, Hungary, Israel, Japan, Korea, Mexico, and New Zealand.

Source: World Bank, World Development Indicators Database and Global Financial Development Database

\section{Drivers of lending-deposit spreads in Colombia}

6. A decomposition of lending-deposit spreads is useful to explore its main determinants: efficiency, contestability and the impact of regulation. For this purpose, the Colombian lending-deposit spread is decomposed following Randal (1998), using balance sheet and income statement data of commercial banks operating in Colombia during 2004-13 provided by the Colombian Superintendence of Finance (SFC). Specifically, profits $(P)$ are defined as the sum of interest income $(I I)$ and non-interest income (NII), minus interest expenses (IP), operating costs $(O C)$, and net provision for loan losses (Prov). After rearranging this identity, the net interest revenue can be expressed as:

$$
I I-I P=O C+\text { Prov }+P-N I I
$$


Dividing this expression by interest bearing liabilities (D), using interest bearing assets (L) and total assets (A) gives:

$$
\frac{I I}{L} \frac{L}{D}-\frac{I P}{D}=\frac{O C}{D}+\frac{P r o v}{D}+\frac{P}{A} \frac{A}{D}-\frac{N I I}{D}
$$

Defining the implicit lending rate $i_{L}$ as the ratio (II/L) and the implicit deposit rate $i_{D}$ as the ratio (IP/D), yields the following formulation of the implicit lending-deposit spread:

$$
\begin{gathered}
i_{L}-i_{D}=\rho \times i_{L}+\frac{O C}{D}+\frac{\operatorname{Prov}}{D}+R O A \times \frac{A}{D}-\frac{N I I}{D}+\varepsilon \\
\text { With } \rho=1-\frac{L}{D},
\end{gathered}
$$

where $R O A$ denotes the return on assets, capturing bank profitability, and $\varepsilon$ is an error term resulting from combining flow (income statement) and stock (balance sheet) data.

7. The above expression decomposes the lending-deposit spread into cost and profit components, highlighting their respective influences on the spread. Following Poghosyan (2012), the different terms can be interpreted in the following way:

- Reserve requirement costs: $\rho \times i_{L}$. The degree to which interest bearing liabilities are turned into interest bearing assets is an essential cost component for banks. Reserve requirements impose an additional cost on banks, because they limit the leverage ratio (L/D) by forcing banks to hold a fraction of their deposits as a buffer. Banks pass this additional cost to their customers by widening the margin.

- Operational costs: $\frac{O C}{D}$. This ratio measures the impact of bank efficiency on the lending-deposit spread. More efficient banks have lower operational costs relative to their less efficient counterparts. They can operate at a lower margin and still secure the same level of profitability as their less efficient peers.

- Credit risk: $\frac{\text { Prov }}{D}$. The ratio of net provision for loan losses to interest bearing liabilities is a proxy of the impact of credit risk on lending-deposit spread. Banks with riskier portfolios have to transfer a larger amount of funds to maintain adequate loan loss provision reserves, which is a cost transferred to customers by increasing $i_{L}$.

- Profitability: $R O A \times \frac{A}{D}$. Banks with higher return on assets are able to extract more profits than their competitors. Increases in profitability can be achieved by requiring higher interest rate on loans or paying less interest on deposits, increasing thereby the lending-deposit spread. Profitability is linked to the level of contestability inside the market: in a market with high monopolistic power, banks will be able to widen the spread with limited consequences on demand.

- Non-interest income: $\frac{N I I}{D}$. Banks earning income from non-traditional banking activities, such as fee-based activities, licensing, insurances, are able to maintain an adequate level of profit while operating at a lower interest margin. Thus an increase in non-traditional activities could create a downward pressure on the lending-deposit spread. 
8. Summing up, the three underlying forces in action in this analysis are efficiency, contestability and regulations. Efficiency determines the level of operational costs as well as the extent to which a firm is able to generate profits. Market contestability determines the level of competitive pressure exerted on firms, influencing the level of efficiency. Regulations have an impact on reserve requirement, credit risk, as well as on the degree of market contestability.

9. Observed and implicit lending-deposit spreads are fairly close and both present a slightly increasing trend in the recent years (Figure 3). This trend is mainly due to a decrease in non-interest income that has not been fully compensated by the decrease in operational costs. Noteworthy, reserve costs have been negative since 2005, indicating that banks on average hold more interest earning assets than interest bearing liabilities. This leveraged position has increased since 2009, but with no clear effect on the lending-deposit spread, as loss provision costs has increased by a similar proportion, due to a riskier loan portfolio. Profitability has slightly decreased in the past decade, but in a proportion that has only a marginal impact on the lending-deposit spread (Table 1).

Figure 3. Bank lending-deposit spread decomposition in Colombia, 2004 - 2013

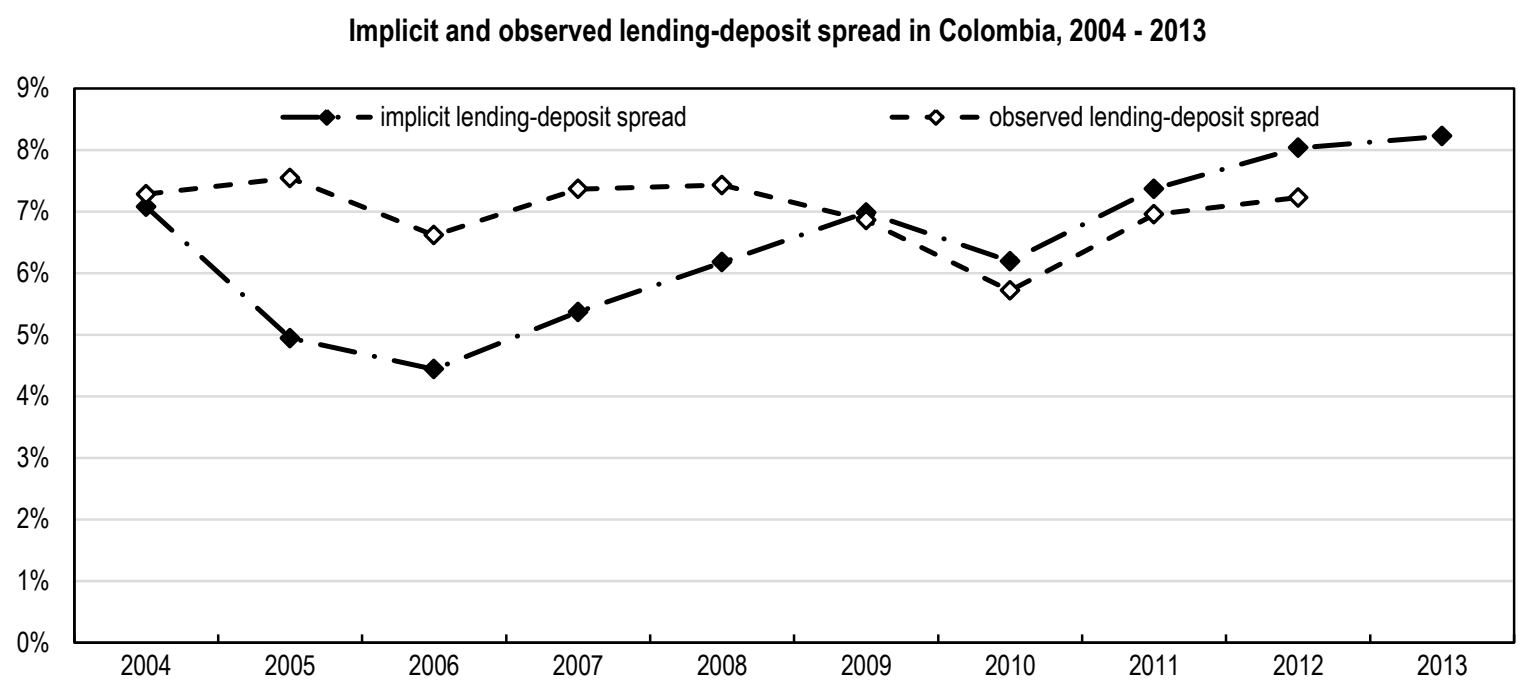

Source: SFC and own calculations for the implicit lending-deposit spread; World Bank, World Development Indicators Database for the observed lending-deposit spread.

10. International comparisons shed light on potential low efficiency and contestability for the Colombian banks. Despite the decline from the 2008-09 levels, operational costs in the Colombian banking sector are still high compared to OECD countries and emerging market economies with similar levels of development (Figure 4, Panel A), which might reflect an efficiency gap of the Colombian banking system. At the same time, profitability in Colombia is high compared to benchmark sample (Figure 4, Panel B). While high levels of profitability is generally a sign of stability and solvency of the banking system, an excessive capacity to make profits is usually also a sign of low contestability. 
Table 1. Implicit lending-deposit spread decomposition in Colombia, 2004 - 2013

(per cent)

\begin{tabular}{|l|llllllllll|}
\hline & $\mathbf{2 0 0 4}$ & $\mathbf{2 0 0 5}$ & $\mathbf{2 0 0 6}$ & $\mathbf{2 0 0 7}$ & $\mathbf{2 0 0 8}$ & $\mathbf{2 0 0 9}$ & $\mathbf{2 0 1 0}$ & $\mathbf{2 0 1 1}$ & $\mathbf{2 0 1 2}$ & $\mathbf{2 0 1 3}$ \\
\hline Implicit lending rate & 12.58 & 9.47 & 8.59 & 10.55 & 12.46 & 12.26 & 9.13 & 10.84 & 12.71 & 12.06 \\
Implicit deposit rate & 5.50 & 4.53 & 4.15 & 5.18 & 6.28 & 5.28 & 2.94 & 3.47 & 4.67 & 3.83 \\
\hline Implicit lending-deposit spread & 7.08 & 4.94 & 4.44 & 5.37 & 6.18 & 6.99 & 6.20 & 7.37 & 8.04 & 8.23 \\
\hline Reserve requirement costs & 1.23 & -0.03 & -0.15 & -0.09 & -2.97 & -0.45 & -0.42 & -1.00 & -1.51 & -1.65 \\
$\quad$ Operational costs & 27.84 & 13.82 & 16.21 & 14.83 & 22.89 & 17.84 & 13.90 & 13.66 & 13.39 & 14.29 \\
$\quad$ Loan loss provision costs & -2.72 & 0.70 & 0.63 & 1.41 & 2.87 & 2.53 & 1.45 & 1.57 & 2.32 & 2.11 \\
Profitability & 5.91 & 3.60 & 2.45 & 2.87 & -2.31 & 1.93 & 1.57 & 3.08 & 3.38 & 1.23 \\
$\quad$ Non-interest income & 25.28 & 12.87 & 14.33 & 13.10 & 13.13 & 14.32 & 10.02 & 9.68 & 9.19 & 7.55 \\
Residual & 0.10 & -0.28 & -0.36 & -0.56 & -1.18 & -0.54 & -0.28 & -0.26 & -0.36 & -0.21 \\
\hline
\end{tabular}

Note: The implicit lending-deposit spread is obtained as the simple average of the individual banks spreads. All commercial banks listed by the SFC were included in the estimation, with the exception of Standard Chartered Colombia which was excluded for the year 2004 which was shut down in 2005 and only represented $0.16 \%$ of total assets in 2004.

Source: Authors' calculations based on SFC data.

Figure 4. Operational costs and profitability in Colombia, emerging and selected OECD countries in 2011

A. Operational costs $(\%$ of total liabilities)

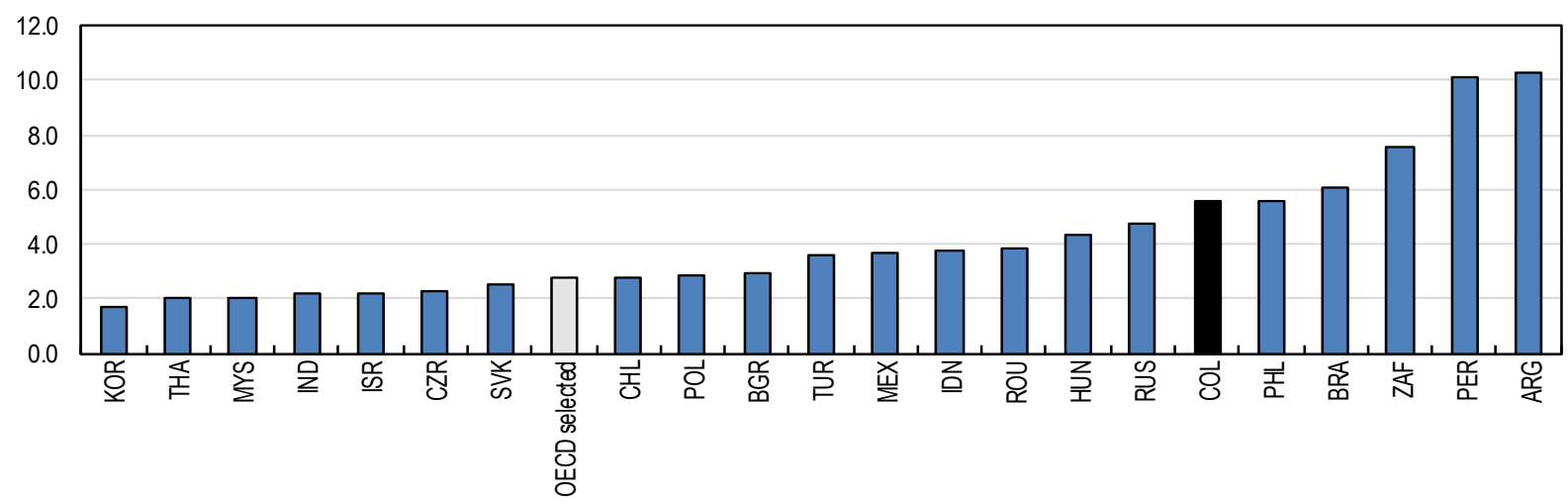

B. Return on assets before tax (profits divided by total assets, \%)

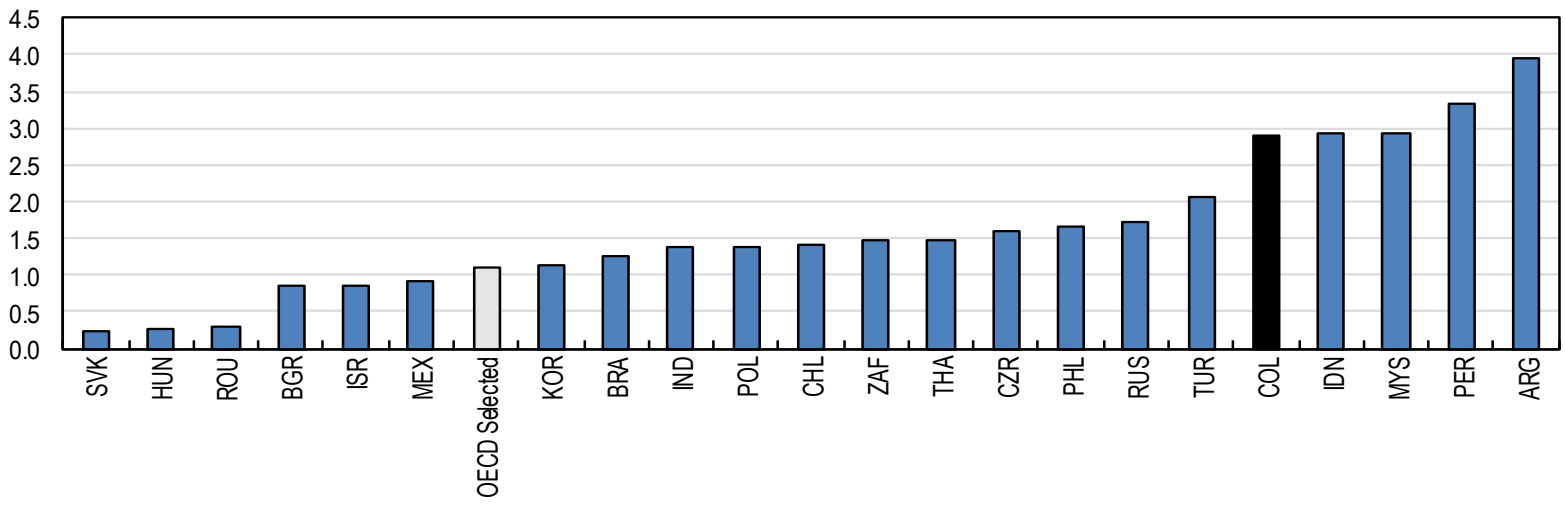

Notes: OECD selected countries includes Chile, Czech Republic, Hungary, Israel, Poland, Slovakia, South Korea and Turkey. Source: Authors' calculations based on Bloomberg and SNL Financial; World Bank, GFDD, IMF for Chile in Panel B. 
11. This accounting model has been useful to identify operating costs and returns on assets as two important drivers of lending-deposit spreads in Colombia. Both are linked to efficiency, contestability and the impact of regulations. However, without imposing more structure on the production function for commercial banks, the potential for deepening further the analysis is limited. In this sense, to better understand the high lending-deposit spreads in Colombia, a more detailed econometric analysis of efficiency and contestability is needed. Before doing so, a closer look at recent Colombian banking sector's evolutions can provide deeper insights about the forces that are shaping its structure.

\section{Increasing concentration with more private and foreign investments}

12. In the past two decades, the Colombian banking system has become more open to private and foreign investments. While at the beginning of the 1990s the system was characterised by a high level of State participation and a relatively low level of contestability (Cuartas et al., 2012), Colombia started to open its financial system to foreign investors and the State's participation in direct banking activities was substantially reduced. For example, while in 1991, state-owned banks represented more than half of the system's total assets, already by 1996 this share had decreased to around 20\%. As a consequence, competition was substantially increased (Barajas, Salazar and Steiner, 1999). Greater contestability, more foreign and private participation in the 1990s led to an increase in financial depth. However, the banking crisis of 1998-2000 was in part a consequence of this rapid expansion credit, as loan quality declined significantly, interest rate hikes to defend the exchange rate put additional pressure on debt servicing, and currency mismatches ended up causing solvency problems once the exchange rate was devaluated (and Kiefer 2007). In the next decade, in addition to building a strong banking regulation and supervision framework, the process of reducing barriers to foreign investment in the system was deepened. Nowadays, the share of foreign-owned banks is around $25 \%$ of total assets, while Banco Agrario is the only stateowned bank left (with a market share of around 5\%).

13. Concentration in the Colombian banking sector has followed an upward trend. The consolidation process stemming from the 1998-2000 crisis was deepened in the next decade (Figure 5, Panel A). Nowadays, the Colombian banking sector is dominated by a few large conglomerates with ten financial institutions holding nearly 86 percent of total financial sector assets and the top three banks, representing about 50 percent of total assets and total gross loans in 2013. While the SFC registered the creation of 9 new banks between 2008 and 2013, they only represent less than 3\% of the Colombian market. Overall, the Colombian banking sector has more toward a greater concentration, but it remains moderate by international standards, similar to the average concentration in Europe (Figure 5, Panel B).

14. Concentration, efficiency and contestability are linked in complex ways. On the one hand, a more concentrated market could create more monopolistic power and therefor reduce incentives for efficiency gains. On the other hand, an increase in concentration could be a sign of an increase in competition and efficiency: more efficient firms are able to gain market shares in a competitive market, resulting in higher concentration. Further, a more concentrated ownership may induce better monitoring and positive spillover in profitability and productivity (Claessens and Djankov, 1999). 
Figure 5. Concentration of the Colombia banking sector

A. Evolution of the Herfindahl-Hirschman Index (HHI) in the Colombian banking sector, $2004-2013$

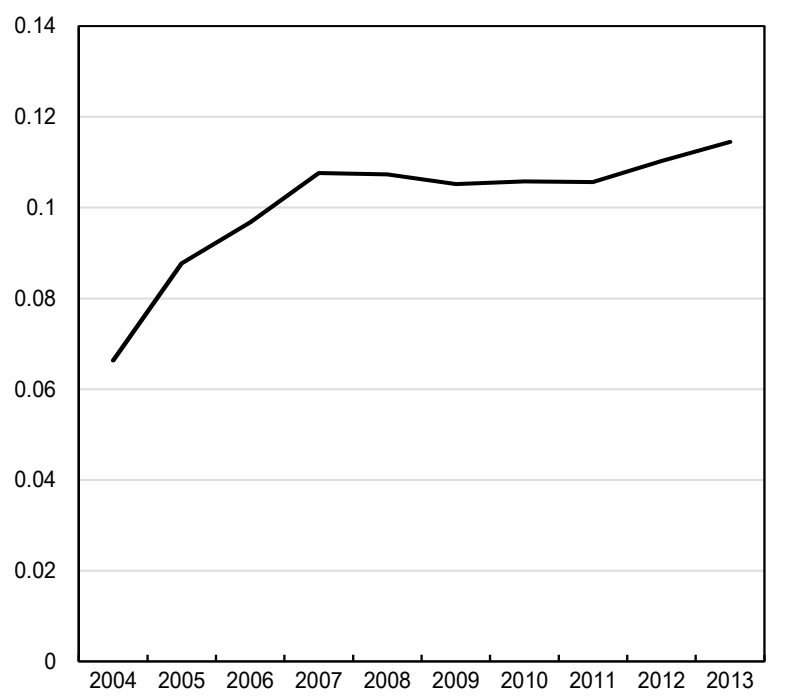

B. HHI - comparison with the European Union area (2013)

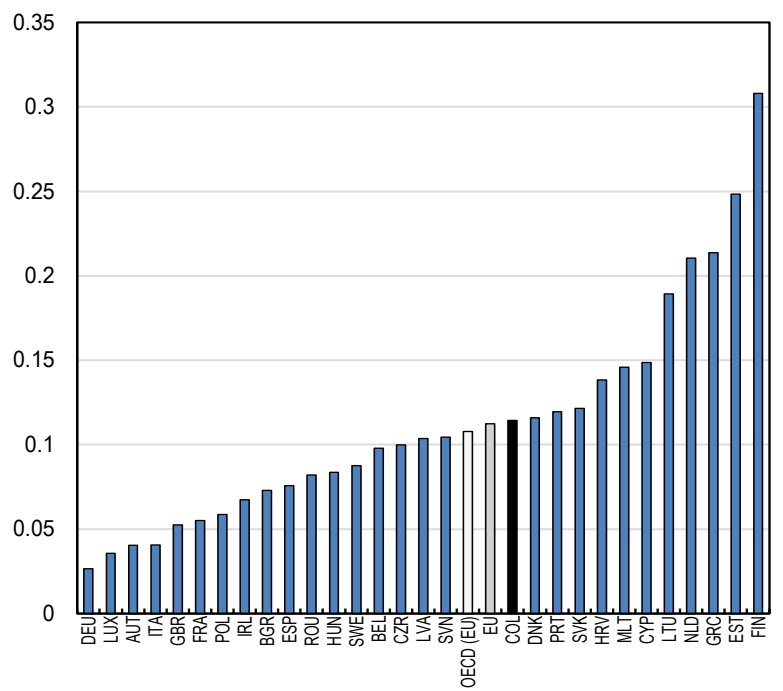

Note: $H H I=\sum_{i=1}^{n} s_{i}{ }^{2}, s_{i}$ representing total assets of bank $\mathrm{i}$ as a the share of the country's total assets. The HHI ranges between $1 / \mathrm{n}$ and 1, reaching its lowest value when all banks in a market are of equal size and one in case of monopoly. The U.S Department of Justice and Federal Trade Commission classify market into three categories according to their HHI: not concentrated (HHI < 0.15$)$, moderately concentrated $(0.15<\mathrm{HHI}<0.25)$, and highly concentrated $(\mathrm{HHl}>0.25)$.

The information in this document with reference to "Cyprus" relates to the southern part of the Island. There is no single authority representing both Turkish and Greek Cypriot people on the Island. Turkey recognizes the Turkish Republic of Northern Cyprus (TRNC). Until a lasting and equitable solution is found within the context of United Nations, Turkey shall preserve its position concerning the "Cyprus" issue

Source: (A) SFC and own calculations (B). Banking Structural Statistical Indicators, European Central Bank; SFC for Colombia

\section{Cost efficiency of the Colombian banking system}

15. This section presents estimates of technical efficiency for a sample of commercial banks for the period 2004-2013 in 23 countries using a stochastic frontier model. Furthermore, a data envelopment analysis is also performed to check the robustness of the resulting technical and allocative efficiency of the Colombian banking sector. Both methods highlight the existence of a gap in technical efficiency for Colombia with respect to OECD and emerging markets benchmark countries.

\section{Technical Efficiency and Allocative Efficiency}

16. Stochastic frontier and data envelopment analyses are both commonly used to measure economic efficiency. Before describing these two methods, it is important to define more clearly efficiency. Modern efficiency measurement begins with Farell (1957), who decomposes efficiency into two components: technical efficiency $(T E)$ and allocative efficiency $(A E)$. The first one measures the ability of a firm to obtain maximal output given a set of inputs. Therefore, technical inefficiency is the loss in production compared to the optimal technology available at the time. Allocative efficiency represents the extent to which firms chose the optimal scale regarding their operations, which is relevant if firms produce under increasing or decreasing returns to scale. To illustrate this idea, one could consider a firm using two inputs $x_{1}$ and $x_{2}$ to produce a single output $y$ under constant returns to scale (Figure 6). The fully efficient firm, represented by the unit isoquant $S S^{\prime}$, allows one to determine technical and allocative efficiencies. A firm producing one unit of $y$, using quantities of inputs represented by the point $P$, is incurring a loss in terms of 
technical efficiency because it could reduce its inputs to point $Q$ while maintaining its level of production. In this example, technical efficiency is measured by the ratio:

$$
T E=O Q / O P
$$

17. A firm with inputs represented by the point $Q$ could still improve its efficiency by moving to point $Q$, where the absolute value of the marginal rate of substitution is equal to the ratio of input prices represented by the slope of the line $A A^{\prime}$. This capacity of improvement is measured by the ratio $(A E)$, which is the allocative efficiency of firm operating at $\mathrm{P}$

$$
A E=O R / O Q
$$

18. The (total) economic efficiency captures both sources of improvement by indicating how much cost could be reduced if the production were to occur at the technical and allocative efficient point $Q^{\prime}$

$$
E E=\frac{O R}{O P}=\frac{O Q}{O P} \times \frac{O R}{O Q}=T E \times A E
$$

Figure 6. Technical and Allocative Efficiencies:

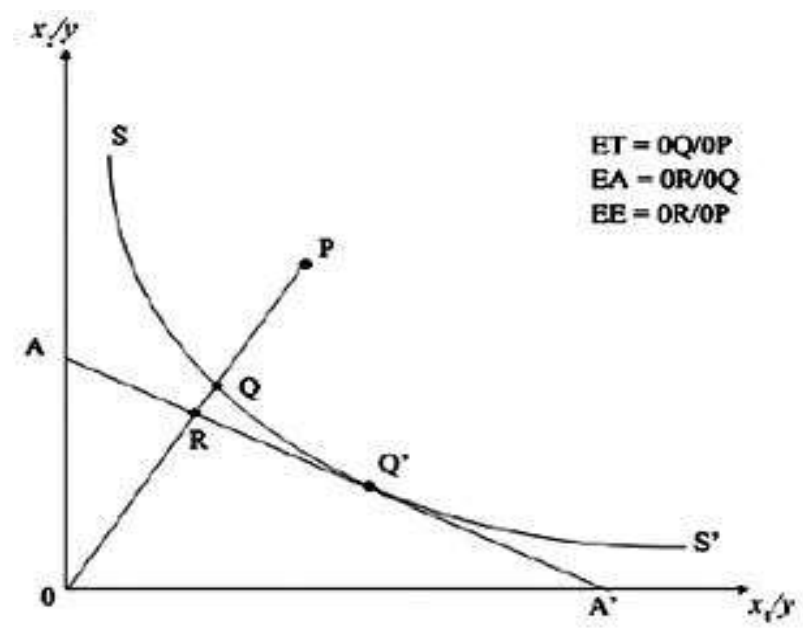

Note: For a more developed description of efficiency, see Coelli (1996) on which the previous example is based Source: Coelli (1996)

19. In practise, the efficient frontier $S S^{\prime}$ is unknown, and parametric as well as non-parametric methods are commonly used to estimate it. The subsequent analysis relies first on a parametric method using a stochastic frontier model to determine technical efficiency in national banking sectors. Second, a non-parametric data envelopment analysis is used to assess the robustness of results and to quantify potential gains from allocative efficiency.

\section{An international comparison based on stochastic frontier estimates}

20. A widespread approach to measuring the efficiency of banks is to estimate a stochastic frontier model, which is motivated by the fundamental idea that no economic agent can exceed the efficient frontier and that deviations from this ideal set of input-output combinations represent the individual inefficiencies in the production process. Stochastic frontier models allow individual observations to be above the efficient frontier because of idiosyncratic disturbances. Thus, the efficiency frontier is not just fixed by the 
most efficient unit in the sample, but also by taking into account the stochastic feature of the data generating process. Hence, these models decompose the error term in two components: one capturing the noise associated with individual observations, and another related to production inefficiencies. Since, Meeusen and van den Broeck (1977) and Aigner et al., (1977), this class of models has become a popular tool for efficiency analysis.

21. In the empirical literature on bank efficiency, two dominant approaches have been used to model cost functions depending on the theoretical view concerning the role of deposits. On the one hand, the production approach sees banks as using labour and capital to produce deposits and loans, considering them as an output in the production process. On the other hand, the intermediation approach puts emphasis on the brokerage role of financial institutions, creating links between savers and investors. Under the former framework, banks are collecting deposits to transform them into financial instruments exchangeable on financial markets. Deposits are them considered as an input. While the production approach is usually considered to be well-suited for modelling branches within the same bank, the intermediation approach is considered more relevant for performing efficiency comparisons (Kosak and Zoric, 2009). Therefore, the present paper, which aims at measuring and comparing efficiency across national banking systems, adopts the intermediation approach. Deposits are an input, used to produce financial goods (earning assets), defined as the sum of total gross loans and securities.

22. A time-varying inefficiency model proposed by Battese and Coelli (1992) is well-suited for a panel data analysis. In particular, the following Cobb-Douglas cost function specification is assumed:

$$
\begin{aligned}
\ln \left(T C_{i t}\right)= & \beta_{0}+\sum_{j=1}^{3} \beta_{j} \ln \left(p_{i t}^{j}\right)+\beta_{4} \ln \left(Y_{i t}\right)+\theta_{1} \frac{\text { total equity }}{\text { total assets }}+\theta_{2} \frac{\text { total loans }}{\text { deposits }}+\text { time trend }+v_{i t}+u_{i t}(1) \\
& T C \text { is total cost defined as the sum of operating expenses and interest expenses } \\
& p^{1}=\frac{\text { personnel expenses }}{\text { total assets }}, \text { proxy for price of labour } \\
& p^{2}=\frac{\text { operating expenses }- \text { personnel expenses }}{\text { total assets }}, \text { proxy for price of equipment } \\
& p^{3}=\frac{\text { interest expenses }}{\text { total liabilities }}, \text { proxy for the price of fundings } \\
& Y_{i t}=\text { earning assets, capturing banks output } \\
& v_{i t} \sim \text { iid } N\left(0, \sigma_{v}^{2}\right) u_{i} \sim \text { iid } N^{+}\left(0, \sigma^{2}\right) \\
& u_{i t}=\exp [-\eta(t-T)] u_{i}
\end{aligned}
$$

23. The idiosyncratic error $\left(v_{i t}\right)$ is associated to the randomness of the data generating process, while $u_{i t}$ is a non-negative half-normal random variable of capturing the distance from the cost efficient frontier, that is the degree of technical inefficiency. Furthermore, the model imposes further structure on the evolution of the degree of technical inefficiency, as the non-negative inefficiency effects $u_{i t}$, decrease, remain constant or increase as $t$ increases if $\eta>0, \eta=0$ or $\eta<0$. The measure of cost efficiency is provided by $\mathrm{CE}_{\mathrm{it}}=\mathrm{e}^{-\mathrm{u}_{\mathrm{it}}}$, ranging from 0 for fully inefficient firms to 1 for firms on the cost efficient frontier. More precisely, this cost efficiency measures technical efficiency, as previously defined.

24. The specification is fairly close to other studies on bank efficiency. However, the price of equipment used is slightly different. It is common to use fixed assets instead of total assets in the denominator of $p^{2}$, for it represents tangible assets - property, plant and equipment. However, fixed assets in the sample appear to be poorly measured for Latin American countries. For example, the correlation between the number of offices and fixed assets is -0.09 percent, while the correlation between the number of ATM and fixed assets is 0.1. Using total assets instead of fixed assets, these correlations increase to 0.48 and 0.44 , respectively. Besides, using fixed assets creates a highly dispersion in the proxy for equipment prices. It is hard to believe that banks are facing extremely dispersed prices for their properties, plants and equipment. Therefore, the normalization by total assets was chosen as a second best solution. 
25. Further, to consider a well-behaved cost function, one should impose homogeneity in factor prices by subtracting $\ln \left(\mathrm{p}_{\mathrm{it}}^{3}\right)$ from both sides of (1) to obtain the equation used for the estimation:

$$
\begin{aligned}
\ln \left(\mathrm{TC}_{\mathrm{it}} / \mathrm{p}_{\mathrm{it}}^{3}\right)= & \beta_{0}+\sum_{\mathrm{j}=1}^{2} \beta_{\mathrm{j}} \ln \left(\mathrm{p}_{\mathrm{it}}^{\mathrm{j}} / \mathrm{p}_{\mathrm{it}}^{3}\right)+\beta_{4} \ln \left(\mathrm{Y}_{\mathrm{it}}\right)+\theta_{1} \frac{\text { total equity }}{\text { total assets }}+\theta_{2} \frac{\text { total loans }}{\text { deposits }}+\text { time trend }+\mathrm{v}_{\mathrm{it}} \\
& +\mathrm{u}_{\mathrm{it}}(2)
\end{aligned}
$$

26. A common cost frontier is estimated for commercial banks of the 23 countries included in the sample. Of course, the cost frontier analysis depends on the units included in it, as the degree of inefficiency is measured by the distance to the cost efficient frontier, which is influenced by the best performing units. Therefore, not all OECD countries were not included, but a selected sample of OECD countries that have closer levels of overall development to Colombia. The sample of OECD members includes Chile, Czech Republic, Hungary, Israel, Poland, Slovakia, Slovenia, South Korea and Turkey. While to some extent these choices were influenced by the quality of the data available on the mentioned countries, their respective banking sectors have return on average assets and net margins higher than the OECD average, closer to Colombia's figures, indicating a closer proximity to Colombian's banking market. Besides, to control for heterogeneity across countries in terms of regulatory conditions and risk preferences, the ratio of equity to assets and the ratio of total loans to deposits are included (Tabak et al., 2011). Furthermore, a time trend is included to allow for technical progress (Battese and Coelli 1992). Finally, in order to test the robustness of the estimation, a second specification for the price of labour is implemented by normalizing labour expenses by the number of employees. The model is estimates by maximum likelihood, where the likelihood function is expressed in terms of the variance parameters, $\sigma_{s}^{2}=\sigma_{v}^{2}+\sigma^{2}$ and $\gamma=\sigma^{2} / \sigma_{s}^{2}$. Estimates for both specifications are presented in Table 2 .

Table 2. Stochastic Frontier Analysis

\begin{tabular}{|c|c|c|c|c|c|c|c|c|}
\hline & \multicolumn{4}{|c|}{ Proxy 1 for price of labour } & \multicolumn{4}{|c|}{ Proxy 2 for price of labour } \\
\hline & Estimate & $\begin{array}{l}\text { Std. } \\
\text { Error }\end{array}$ & $\begin{array}{c}\mathbf{z} \\
\text { value }\end{array}$ & $\begin{array}{c}\operatorname{Pr}(>|z|) \\
(\%)\end{array}$ & Estimate & $\begin{array}{l}\text { Std. } \\
\text { Error }\end{array}$ & $\begin{array}{c}z \\
\text { value }\end{array}$ & $\begin{array}{c}\operatorname{Pr}(>|z|) \\
(\%)\end{array}$ \\
\hline (Intercept) & 1.54 & 0.03 & 44.46 & 0.0 & 1.66 & 0.04 & 37.53 & 0.0 \\
\hline Log(earning assets) & 0.96 & 0.00 & 249.05 & 0.0 & 0.92 & 0.01 & 169.51 & 0.0 \\
\hline Log(price labour) & 0.22 & 0.01 & 26.77 & 0.0 & 0.12 & 0.01 & 17.24 & 0.0 \\
\hline Log(price equipment) & 0.29 & 0.01 & 41.99 & 0.0 & 0.34 & 0.01 & 50.84 & 0.0 \\
\hline Equity/assets & -0.70 & 0.09 & -8.12 & 0.0 & -0.51 & 0.09 & -5.52 & 0.0 \\
\hline Loans/deposits & -0.04 & 0.01 & -6.98 & 0.0 & -0.05 & 0.01 & -6.55 & 0.0 \\
\hline Time trend & 0.01 & 0.00 & 3.65 & 0.0 & 0.00 & 0.00 & -1.88 & 6.0 \\
\hline$\sigma_{s}^{2}$ & 0.08 & 0.01 & 14.54 & 0.0 & 0.13 & 0.01 & 10.81 & 0.0 \\
\hline$\gamma$ & 0.79 & 0.02 & 49.69 & 0.0 & 0.88 & 0.01 & 72.85 & 0.0 \\
\hline$\eta$ & 0.04 & 0.01 & 5.39 & 0.0 & -0.01 & 0.01 & -0.86 & 38.8 \\
\hline Log-likelihood value & 1485.646 & & & & 1261.594 & & & \\
\hline Number of observations & 3407 & & & & 2625 & & & \\
\hline
\end{tabular}

Note: proxy 1 for price of labour = labour expenses/total assets, proxy 2 the price of labour = labour expenses/number of employees. 
27. Under the first specification, cost efficiency in Colombia is close to $87 \%$, while under the second specification, cost efficiency is about $82 \%$. Hence, the average of the two specifications is about $85 \%$ indicating significant potential gains from improvements in the management of inputs and in the production process. However, Colombia's banking sector cost efficiency is only slightly below the average of the nine OECD countries included in our sample which is about 86\% (Figure 7). Furthermore, according to this stochastic frontier analysis, Colombia is the second most efficient countries of the Latin American countries included in our sample, behind Chile, but more cost-efficient than Brazil, Peru and Argentina.

Figure 7. Stochastic frontier analysis, commercial banking sectors' average cost efficiency, 2004 - 2013

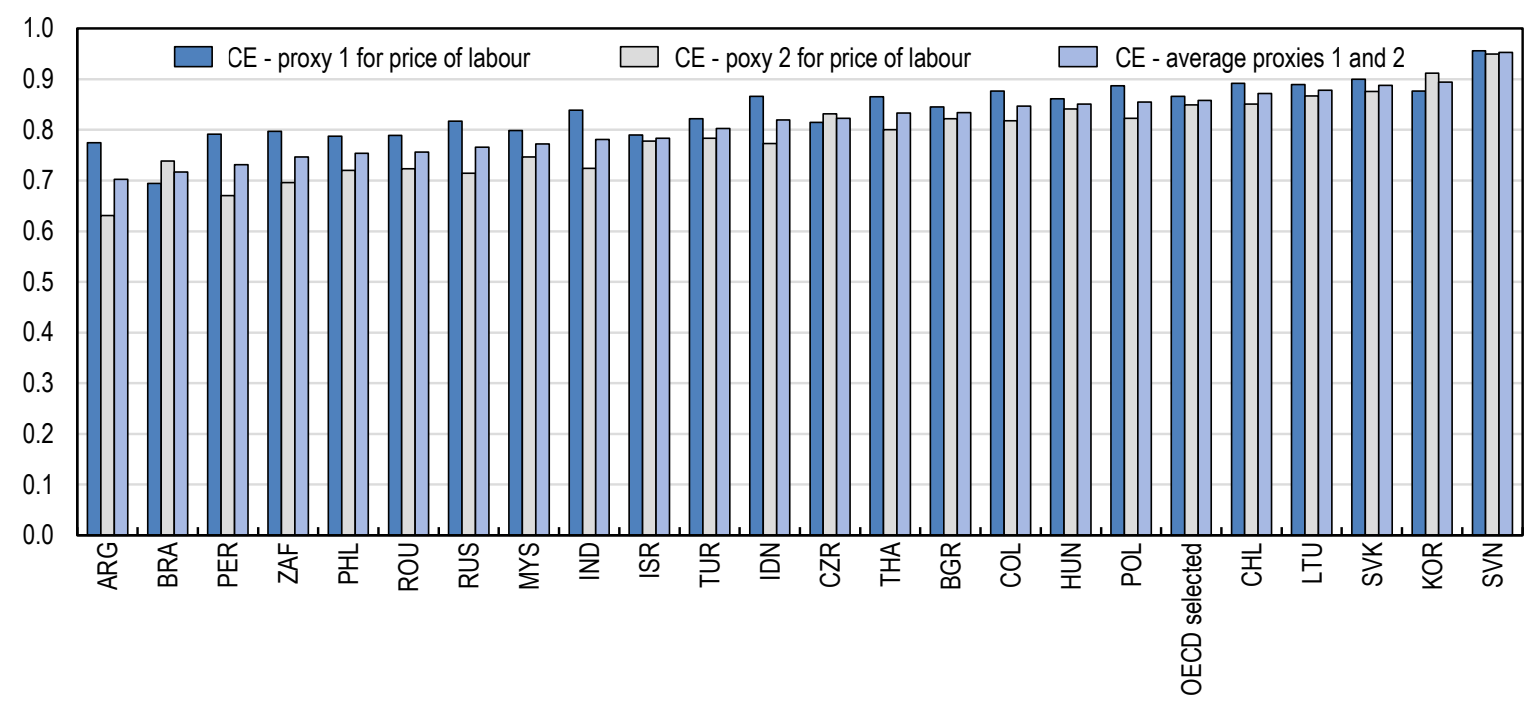

Notes: Cost efficiency (CE) is a measure of the relative distance from the efficient frontier. It ranges between 1 and 0 for a fully efficient and a fully inefficient firm respectively. OECD selected countries includes Chile, Czech Republic, Hungary, Israel, Poland, Slovakia, Slovenia, South Korea and Turkey. Proxy 1 for price of labour = labour expenses/total assets, proxy 2 the price of labour $=$ labour expenses/number of employees.

Source: Authors' calculation based on data from Bloomberg and SNL Financial.

Figure 8. Evolution of cost efficiency in Colombia

(balanced panel)

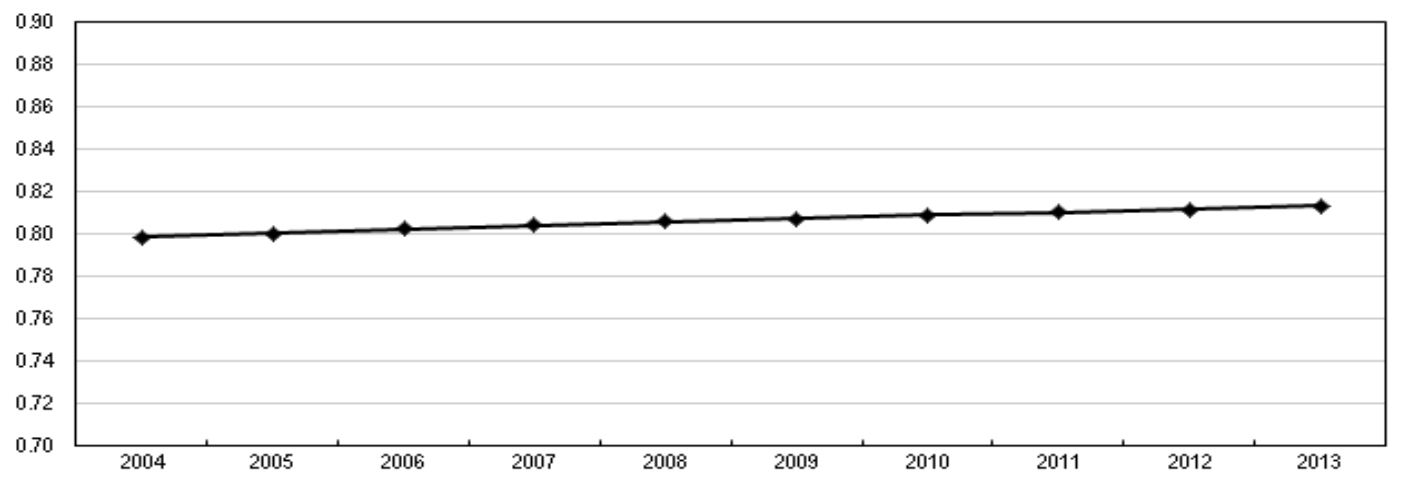

Notes: The represented cost efficiency is the average of Colombian banks efficiency scores with no missing value over the period $2004-2013$ (obtained from regressions summarized in Table 2). The aggregate efficiency score obtained offers an estimate that is free from variations stemming from bank entering or leaving the sample because of missing values (not representative of a change in the Colombian banking market). Besides, technological progress was taken into account when evaluating the efficient frontier. Hence, variations in technical efficiency can be interpreted as changes in practices

Source: Authors' calculation based on data from Bloomberg and SNL Financial. 
28. Cost efficiency shows signs of limited improvements during the period $2004-2013$. Under specification 1, the $\eta$ coefficient is positive and significantly different from zero, indicating an increasing trend in efficiency, even after controlling for technological change. However, under specification 2, it is not significantly different from zero, indicating an invariant rather time-invariant cost efficiency. On average, cost efficiency improvements in the sample seem therefore limited. The same holds for Colombia. Using a balanced panel of banks to avoid changes in efficiency due to a composition effect driven by entry and exit, the results show that cost efficiency has barely changed in the period 2004-13 (Figure 8).

29. Differences in estimates between the two specifications do not stem from a composition effect of the sample. As the number of employees is more often missing than information about total assets, there the sample for proxy 1 is larger. However, when restricting the sample for both specifications to the same observations (2625 observations) the results reported in Table 2 and Figure 7 are not altered significantly. Rankings across countries are preserved and cost efficiency scores at country's level are not significantly affected (with an average change of less than 0.01 in absolute values).

30. A series of robustness tests - not reported due to space limitations - show that the results presented here are robust. For example, the previous results are not affected by removing the technological trend; neither by allowing the inefficiency terms $u_{i t}$ to be a truncated normal random variable instead of a half-normal one. Robustness test also included estimating the model without controlling for differences in equity to total assets ratio and loans to deposits ratio, or taking the logarithm of these control variables. Finally, a translog cost function was used instead of a Cobb-Douglas. All these alternative specifications did not affect the overall results exposed previously, with the exception of the translog cost function which slightly increased the average cost efficiency for the whole sample, although it did not produced substantial differences in the ranking among countries. Thus, the relative rank between countries in terms of cost efficiency is probably more robust than the absolute value of the cost efficient coefficient, which depends to some extent on the functional form assumed. In this sense, a data envelopment analysis allows for fewer restrictions on the functional form.

\section{Further insights on cost efficiency in Colombia from a data envelope analysis}

31. The previous analysis of efficiency relied on the assumption of a parametric form for the cost function. This restriction is released by evaluating the efficient frontier using a data envelope analysis (DEA), which is a non-parametric linear programming approach to frontier estimation. This second analysis gives further insights about the robustness of the stochastic frontier analysis (SFA) findings and allows quantifying potential gains from allocative efficiency in the Colombian banking sector. In particular, the model is solved for the following three sets of linear systems:

$$
\begin{gathered}
\left.\min _{\{\theta, \lambda\}} \theta \quad \text { (system } 1\right) \\
\text { s.t. }-\boldsymbol{q}_{\boldsymbol{i}}+\boldsymbol{Q} \boldsymbol{\lambda} \geq 0 \\
\theta \boldsymbol{x}_{\boldsymbol{i}}-\boldsymbol{X} \boldsymbol{\lambda} \geq \mathbf{0} \\
\boldsymbol{\lambda} \geq \mathbf{0} \\
\left.\min _{\{\theta, \lambda\}} \theta \quad \text { (system } 2\right) \\
-\boldsymbol{q}_{\boldsymbol{i}}+\boldsymbol{Q} \boldsymbol{\lambda} \geq \mathbf{0} \\
\theta \boldsymbol{x}_{\boldsymbol{i}}-\mathbf{X} \boldsymbol{\lambda} \geq \mathbf{0} \\
\mathbf{I} \mathbf{1}^{\prime} \boldsymbol{\lambda}=\mathbf{1} \\
\boldsymbol{\lambda} \geq \mathbf{0} \\
\min _{\{\theta, \lambda\}} \theta \quad(\text { system } 3) \\
-\boldsymbol{q}_{\boldsymbol{i}}+\boldsymbol{Q} \boldsymbol{\lambda} \geq \mathbf{0} \\
\theta \boldsymbol{x}_{\boldsymbol{i}}-\boldsymbol{X} \boldsymbol{\lambda} \geq \mathbf{0} \\
\mathbf{I} \mathbf{1}^{\prime} \boldsymbol{\lambda} \leq \mathbf{1} \\
\boldsymbol{\lambda} \geq \mathbf{0}
\end{gathered}
$$


32. There are $N$ inputs and $M$ outputs for each of $I$ firms ${ }^{2}$. Firm $i$ 's input and output vectors are represented by $\boldsymbol{x}_{\boldsymbol{i}}$ and $\boldsymbol{q}_{\boldsymbol{i}}$ respectively, while the $I$ firms are represented by the $N \times I$ input and the $M \times I$ output matrices $\boldsymbol{X}$ and $\boldsymbol{Q} \cdot \theta$ is a scalar of efficiency score for the i-th firm which satisfies $\theta \leq 1$ (=1, for a fully efficient firm), $\boldsymbol{\lambda}$ is a $I \times 1$ vector of constants and $\mathbf{I} \mathbf{1}$ is an $I \times 1$ vector of ones.

33. System 1 seeks to radially contract the input vector $\boldsymbol{x}_{\boldsymbol{i}}$, while remaining within the feasible input set. The inner-boundary of this set is a piece-wise linear isoquant determined by the observed data points. The radial contraction of the input vector $\boldsymbol{x}_{\boldsymbol{i}}$ is a projected point on the surface of the production technology $T$ which defines a production set that is closed, convex, and exhibits constant returns to scale (CRS).

$$
T=\{(\boldsymbol{x}, \boldsymbol{q}): \boldsymbol{q} \leq \boldsymbol{Q} \boldsymbol{\lambda}, \mathbf{x} \geq \mathbf{X} \boldsymbol{\lambda}\}
$$

34. System 2 allows for variable returns to scale (VRS) by adding the convexity constraint $\mathbf{I 1}^{\prime}=1$, which creates a convex hull of intersecting planes that envelope the data points. This constraint ensures that inefficient firms are only compared against firms of similar size, such that, the projected point of a firm on the DEA frontier is a convex combination of observed firms. Efficiency of scale is determined by conducting both a CRS (system 1) and a VRS DEA (system 2). If there is a difference in the CRS and VRS technical efficiency scores for a particular firm, this indicates scale inefficiency. To determine the nature of scale efficiency, one has to substitute the restriction $\mathbf{I} \mathbf{1}^{\prime}=1$ with $\mathbf{I 1}^{\prime} \leq 1$ (system 3 ) to obtain a frontier exhibiting non-increasing returns to scale (NIRS). If VRS and NIRS technical efficiency scores are unequal (equal) for the $i$-th firm, then it operates under increasing (decreasing) returns to scale.

35. Inputs and output are defined the following way, in line with the intermediation approach adopted previously, to insure consistency with the stochastic frontier analysis:

$$
\begin{aligned}
& x^{1}=\text { personnel expenses } \\
& x^{2}=\text { operating expenses }- \text { personnel expenses } \\
& x^{3}=\text { interest expenses }
\end{aligned}
$$

$q^{1}=$ earning assets

36. The three systems of equations previously defined are solved for our dataset on a yearly-basis (Table A.1). However, one should not consider changes in efficiency scores as measuring a trend, but rather as a series of cross-sectional comparisons. 
Figure 9. Technical efficiency with variable return to scale, average $2004-2013$

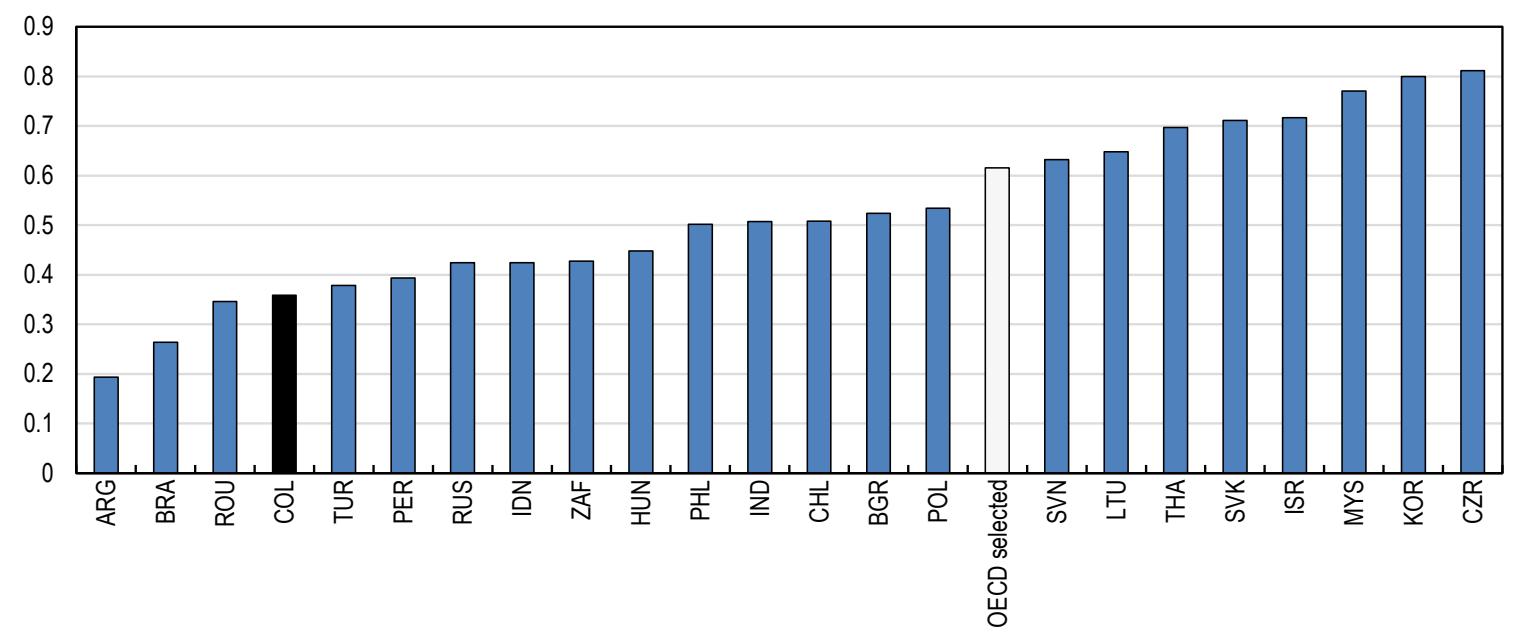

Note: Variable return to scale efficiency (VRS TE) is a measure of the relative distance from the efficient frontier. To control for possible returns to scale, banks are only compared against banks of similar size. It ranges between 1 and 0 for a fully efficient and a fully inefficient firm respectively.

Source: Authors' calculations based on data from Bloomberg and SNL Financial.

37. Technical efficiency for the Colombian banking sector appears to be smaller when measured with the DEA method as Colombia ranks 20th on 23 for the period 2004 - 2013 (Figure 9), while it ranks 8th using a SFA. The 'real' technical efficiency is unobservable and probably lies between the two estimates. Taking a simple average between the technical efficiency estimates of both methods, Colombia ranks 17th out of the 23 countries considered in the sample, which indicates a relatively low level of technical efficiency.

38. Results presented in Figure 9 are robust to several tests. In particular, estimating the DEA using a pooled sample including all observations instead of the year-by-year estimation, as well as using a bootstrapping algorithm to correct for the bias induced by using observed data to compute the efficient frontier (Simar and Wilson, 1998) does not alter the results significantly. In both cases, the resulting technical efficiency is slightly smaller for the whole sample (less than 0.1 point shift downward on average), but the ranking across countries is preserved. In the first case, the small decrease in technical efficiency comes from the slight expansion of the technological frontier over time, while in the second case it comes from assuming there is noise in the frontier estimation.

39. There is a high level of scale efficiency in most countries included in the sample, indicating that the main source of improvement lies in technical efficiency changes rather in scaling operations differently (Figure 10, Panel A). While none of the Colombian banks are fully scale-efficient between 2004 and 2013, the loss incurred is small as the aggregate score for Colombia is close to unity (0.96), above the average for OECD in the sample (0.93). On average, Colombian banks are operating under decreasing returns to scale over the period, indicating potential gains from scaling down activities (Figure 10, Panel B). Countries for which significant gains could be achieved in rescaling their activities are Russia, Indonesia, and Peru; with a clear majority of banks with increasing return to scale for the first three them. 
Figure 10. Data envelopment analysis, scale efficiency

A. Average scale efficiency, $2004-2013$

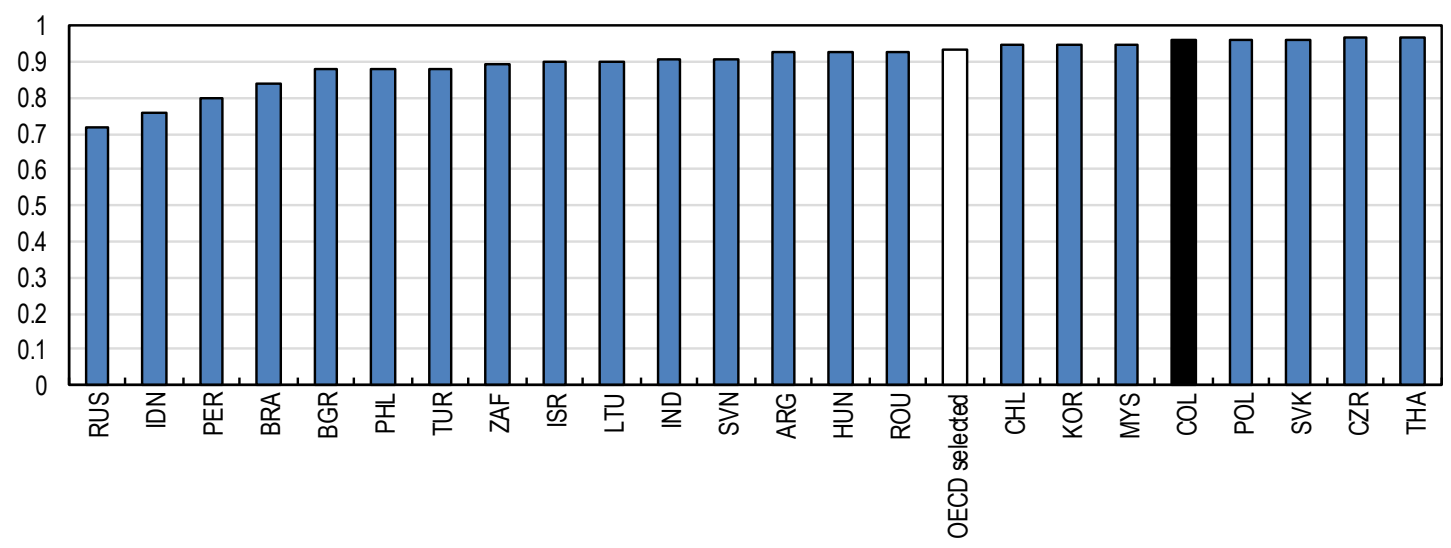

B. Share of bank with scale inefficiencies, $2004-2013$

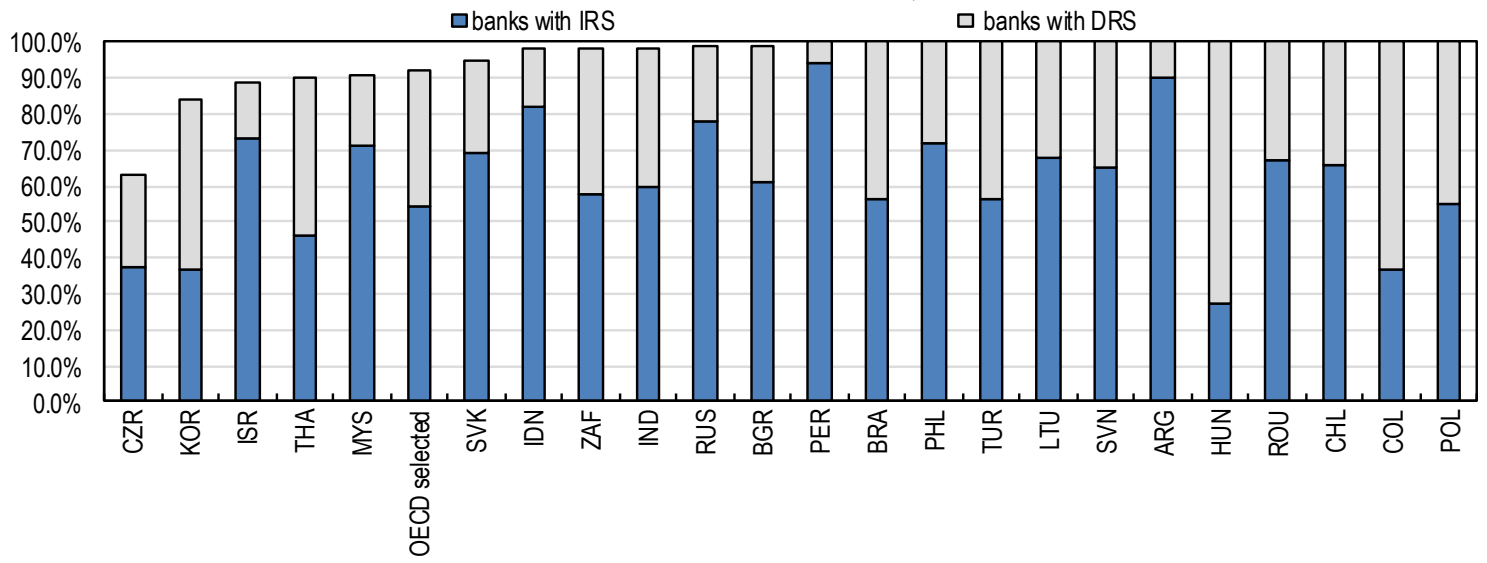

Note: Scale efficiency (or allocative efficiency) measures to what extent banks chose optimally their scale of operations. Allocative inefficiency occurs when banks are producing under increasing or decreasing return to scale (IRS or DRS). An allocative efficient bank has a scale efficiency equal to 1 and is neither under IRS or DRS. A scale efficiency between 1 and 0 indicates the potential to increase production at fixed inputs by increasing or decreasing the scale of production, depending on whether the firms is under IRS or DRS.

Source: Authors' calculations based on data from Bloomberg and SNL Financial

40. The DEA and SFA give different pictures of the magnitude of the efficiency gaps. There are at least three reasons why this could happen. First, there is a fundamental difference in the way both methods address the estimation of the efficient frontier: the SFA model takes into account the randomness of the production process while the DEA is 'deterministic' ${ }^{3}$.In SFA, nobody is on the frontier; while for the DEA, somebody has to be on the frontier. However, this would bias the DEA estimates upwards, such that the bias-corrected DEA estimates would indicate a lower efficiency, as illustrated above. Second, in the SFA method, one has to assume a functional form for the cost function as well as for the composite error term, while no arbitrary choice is made running a DEA. Thirdly, the SFA fully embraces the panel structure of our dataset, while the DEA used here neglects this aspect. 


\section{Cost Efficiency Determinants: regulations and individual bank effects}

41. So far the inefficiency term was unexplained; but it can be endogenized by using the approach developed by Battese and Coelli (1995). This is a one-stage procedure that estimates simultaneously the stochastic frontier, as well as the determinants of the inefficiency terms. Previous studies on banking efficiency have used a two-stage approach, in which the efficiency estimates of a first step are regressed on a vector of explanatory variables in a second stage (Nikiel and Opiela 2002, Bonin et al., 2005). However, this approach suffers from potentially substantial biases (Wang and Schmidt, 2002).

42. The econometric model relies on the Battese and Coelli (1992) model, adding the assumption that the individual inefficiency terms $u_{i t}$ - the non-negative truncation (at zero) of the normal distribution - are linearly dependent on a vector $\boldsymbol{z}_{i t}$ of explanatory variables:

$$
\begin{gathered}
\ln \left(T C_{i t}\right)=\beta_{0}+\sum_{j=1}^{3} \beta_{j} \ln \left(p_{i t}^{j}\right)+\beta_{4} \ln \left(Y_{i t}\right)+\beta_{5} \text { year }+v_{i t}+u_{i t}(3) \\
u_{i t}=\mathbf{z}_{i t} \boldsymbol{\delta}+w_{i t}(4),
\end{gathered}
$$

where the random variable $w_{i t}$ has the truncated normal distribution with zero mean and variance $\sigma^{2}$, hence the inefficiency component $u_{i t}$ is a non-negative truncation of $N\left(z_{i t} \delta, \sigma^{2}\right)$. The vectors of unknown coefficients $\boldsymbol{\beta}$ and $\boldsymbol{\delta}$ are simultaneously estimated by maximum likelihood. Cost efficiency estimates are expressed as $\mathrm{CE}_{\mathrm{it}}=e^{-u_{i t}}=\mathrm{e}^{-z_{i t} \delta-w_{i t}}$

43. The vector of explanatory variables used in the analysis of the present paper contains two categories: one that captures national banking structures and regulations and another one that takes into account banks individual characteristics. The idea is that bank efficiency is a function of the structural characteristics of the national market in which it operates as well as individual characteristics.

44. The following variables are included within the bank-specific characteristics: i) the ratio of equity to assets; ii) the ratio of total loans to deposits; and iii) the net interest margin defined as the difference between interest income and interest expenses (divided by total assets). Net interest margins are closely related to the lending-deposit spread. One hypothesis was that more efficient banks operate at smaller operating costs while still securing sufficient profits; hence they can reduce their lending-deposit spread

45. Some aspects of financial regulation are included among the country-specific variables. To measure the impact of the regulative framework on bank performances, an index capturing the official power of the supervisory of the banking sector is introduced. This index measures the extent to which the supervisor is able to take specific actions to prevent and correct problems in the banking system and institutions. The data come from three surveys by the World Bank in 2003, 2007 and 20114, where senior banking supervisors were asked several questions relative to the power and independence of the national supervisory entity. Values were assigned to each answer to create an index ranging from 0 to 14 , with higher values indicating more power for the official supervisory entity to prevent and correct issues (see Box A.1 for the questions used). In addition, an index capturing activity restrictions on banking activities based on the same survey is considered. This index measures the extent to which banks may engage in securities, insurance and real estate activities. It ranges from 3 to 14; with higher value indicating more restrictions on banking activities (see Box A.2). While a stronger power of supervisory is theory would lead to more efficiency, the impact of activity restrictions is less clear in theory. On the one hand, these restrictions might induce more competition and raise efficiency. On the other hand, they might prevent banks to fully benefit from economies of scope and therefore reduce cost efficiency. 
46. Structural characteristics are likely to have an impact on efficiency scores. First, as discussed above, concentration might have a positive or negative impact on banks efficiency. To evaluate this issue, the share of assets detained by the five largest banks is included as an explanatory variable. Second, the percentages of public as well as the share of foreign banks in the national market are considered. A bank is considered as public if more than fifty percent of its share is owned by the government. An equivalent definition is used to define foreign ownership. The rationale for including these variables is that spill-over effects could arise in a given market. For instance, foreign banks could facilitate the diffusion of new technologies and management knowledge, enhancing the efficiency of competitors, while the presence of public banks might reduce market competition and efficiency.

Figure 11. Evolution of regulative and structural characteristics of banking sectors
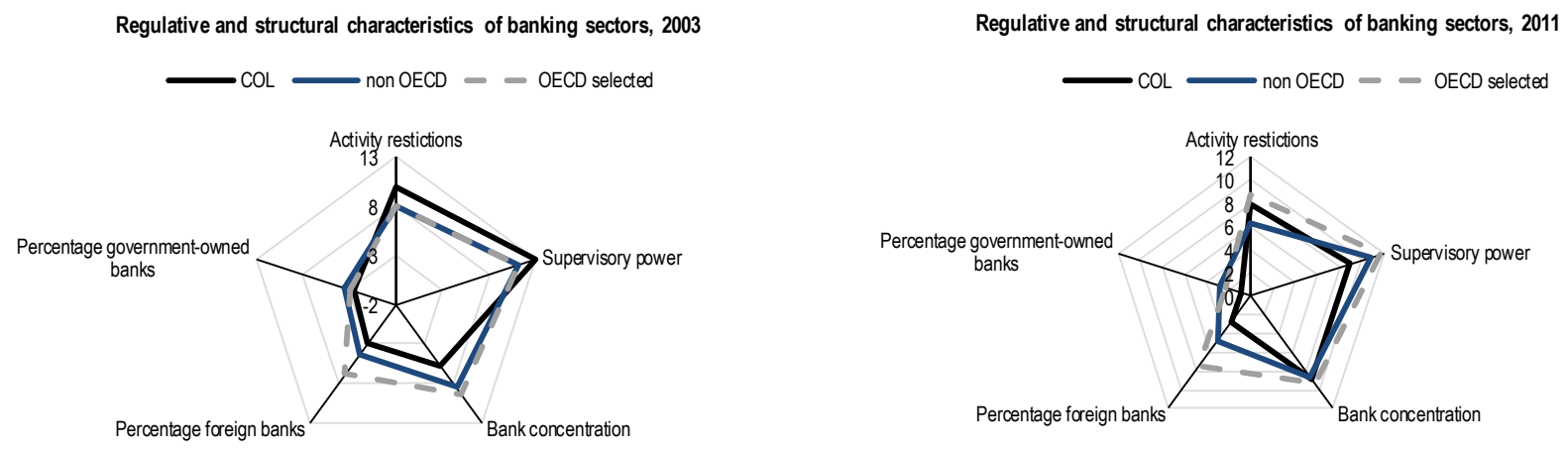

Notes: Supervisory power and activity restrictions on banking activities are captured by indexes belonging to the interval $[0,14]$. Bank concentration (share of the assets detained by the five largest bank of the national market), percentages of foreign and public banks have converted into the interval $[0,14]$ to allow for a visual representation $(0$ and 14 corresponding to $0 \%$ and $100 \%$ respectively). OECD selected countries include Chile, Czech Republic, Hungary, Israel, Poland, Slovakia, Slovenia, South Korea and Turkey. Non OECD countries include Argentina, Bulgaria, Brazil, Indonesia, India, Lithuania, Malaysia, Peru, Philippines, Poland, Romania, Russia, Slovakia, Thailand, and South Africa.

Source: World Bank, World Bank Surveys on Bank Regulation.

47. Figure 11 offers a synthesis of the evolution of the Colombian banking sector in the different structural and regulatory aspects considered. Concerning regulative characteristics, the official power of the Supervisory authority and restrictions on banking activities have declined between 2001 and 2010 . Higher than the average of the OECD banking sectors included in the sample in 2001, they both appear below OECD it in 2010. In terms of structural characteristics, the share of public banks has decreased, while concentration increased to OECD levels. The share of foreign banks has remained relatively stable, at low levels by OECD and non OECD countries standards.

48. Country-specific variables for the period 2004-11 were obtained by linear interpolation (using least squares). Only banks belonging to countries with at least two observations from the World Bank Survey on Financial Survey were retained. Furthermore, in order to facilitate convergence in the maximum likelihood estimates, the homogeneity assumption in the factor prices for the cost function is relaxed. To take into account both technical change and time-varying inefficiency effects, a time trend is included both equations (3) and (4). In equation (3), the time trend captures the Hicksian neutral technological change, while in equation (4) it means that inefficiency effects may be a linear function of time (as in Battese and Coelli, 1995). Country fixed effects included to control for unobservable that might be correlated with the explanatory variables. 
Table 3. Joint estimation of the cost frontier and inefficiency determinants

\begin{tabular}{|c|c|c|c|c|c|c|c|c|}
\hline & \multicolumn{4}{|c|}{ Proxy 1 for price of labour } & \multicolumn{4}{|c|}{ Proxy 2 for price of labour } \\
\hline & Estimate & $\begin{array}{l}\text { Std. } \\
\text { Error }\end{array}$ & $z$ value & $\begin{array}{c}\operatorname{Pr}(>|z|) \\
(\%)\end{array}$ & Estimate & $\begin{array}{l}\text { Std. } \\
\text { Error }\end{array}$ & $z$ value & $\begin{array}{c}\operatorname{Pr}(>|z|) \\
(\%)\end{array}$ \\
\hline \multicolumn{9}{|l|}{ Stochastic frontier } \\
\hline Intercept & 1.12 & 0.04 & 30.10 & 0.0 & 0.84 & 0.06 & 13.27 & 0.0 \\
\hline Log(earning assets) & 0.99 & 0.00 & 490.74 & 0.0 & 1.00 & 0.00 & 400.76 & 0.0 \\
\hline Log(price labour) & 0.19 & 0.01 & 19.26 & 0.0 & 0.02 & 0.01 & 2.53 & 1.0 \\
\hline Log(price equipment) & 0.25 & 0.01 & 29.95 & 0.0 & 0.35 & 0.01 & 43.21 & 0.0 \\
\hline Log(price funds) & 0.55 & 0.01 & 78.71 & 0.0 & 0.57 & 0.01 & 63.12 & 0.0 \\
\hline Time trend & -0.01 & 0.00 & -3.90 & 0.0 & 0.00 & 0.00 & -1.40 & 16.0 \\
\hline \multicolumn{9}{|l|}{ Inefficiency model } \\
\hline Intercept & -0.22 & 0.67 & -0.33 & 74.4 & -1.33 & 0.67 & -2.00 & 5.0 \\
\hline Equity/assets & 0.32 & 0.34 & 0.95 & 34.3 & 1.63 & 0.32 & 5.19 & 0.0 \\
\hline Loans/deposits & -0.66 & 0.09 & -7.21 & 0.0 & -1.30 & 0.15 & -8.93 & 0.0 \\
\hline Net margin & 1.11 & 0.47 & 2.36 & 1.9 & 2.18 & 0.31 & 7.13 & 0.0 \\
\hline Supervisory power & -0.17 & 0.04 & -4.71 & 0.0 & -0.04 & 0.03 & -1.53 & 12.0 \\
\hline Activity restrictions & -0.07 & 0.03 & -2.21 & 2.7 & -0.08 & 0.03 & -3.09 & 0.0 \\
\hline Market concentration & -0.01 & 0.01 & -1.34 & 18.0 & 0.02 & 0.01 & 2.44 & 1.0 \\
\hline Public banks share & 0.06 & 0.01 & 4.18 & 0.0 & 0.05 & 0.01 & 4.15 & 0.0 \\
\hline Foreign banks share & -0.04 & 0.01 & -4.87 & 0.0 & 0.01 & 0.01 & 1.58 & 12.0 \\
\hline Time trend & -0.01 & 0.01 & -0.75 & 45.3 & -0.02 & 0.01 & -2.23 & 3.0 \\
\hline \multicolumn{9}{|l|}{ Variance parameters } \\
\hline$\sigma_{s}^{2}$ & 0.46 & 0.07 & 6.99 & 0.0 & 0.12 & 0.01 & 15.43 & 0.0 \\
\hline$\gamma$ & 0.99 & 0.00 & 671.69 & 0.0 & 0.91 & 0.01 & 120.29 & 0.0 \\
\hline Log-likelihood value & 1002.321 & & & & 830.0376 & & & \\
\hline Number of observations & 1964 & & & & 1964 & & & \\
\hline
\end{tabular}

Notes: Proxy 1 for price of labour = labour expenses/total assets, proxy 2 the price of labour = labour expenses/number of employees. The inefficiency model includes country specific effects. The inefficiency terms $u_{i t}$ has the following form $u_{i t}=\boldsymbol{z}_{i t} \boldsymbol{\delta}+w_{i t}$. Hence a positive sign for a component of $\boldsymbol{\delta}$ indicates it tends to increase inefficiency, hence to decrease cost efficiency.

49. Table 3 reports two specifications of the model described by (3) and (4) depending on the type of proxy for the price of labour used. At the bank level, the results show that the ratio of equity to assets is positively correlated with inefficiency. Thus, on average when a bank increases its leverage (by decreasing its equity to assets ratio), it increases its efficiency. However, it could also be a result of reverse causality: more efficient banks might be able to expand its activities. In line with this result, an increase in the loans to deposits ratio is associated with an increase in efficiency. More interestingly, Table 3 also suggests that a decrease in the net margin is associated with an increase in efficiency. This provides evidence consistent with the hypothesis that the high intermediation cost for Colombia is partly explained by a technical efficiency gap with respect to more efficient OECD counterparts. To put differently, to some extent, high intermediation costs can be viewed as the cost of inefficiency. The two last results are robust as the coefficients associated with loans to deposits ratio and net interest margin are statically significant independently of the specification chosen. 
50. There are also three interesting results regarding regulations and market structures. First, the power of the supervising authority is associated with higher banks efficiency. This might reflect that strong supervision helps level the field for all competitors and is consistent with findings for OECD economies (Ahrend et al., 2009). Second, restrictions on banking activities are found to be positively correlated with an increase in efficiency. Third, when the share of public banks is associated with negative spill-overs among the competitors and higher levels of inefficiency. Thus, a decrease in the share of public banks might increase competitive pressures, resulting in efficiency gains.

51. Interestingly, the percentage of foreign banks has no clear effect on technical efficiency, as the sign of the associated coefficient depends on the specification chosen. This reflects also the results in the literature regarding the impact of foreign entry on efficiency, which has not reached a consensus on the matter (Wezel, 2010). While in the first specification a higher share of foreign banks is associated with higher levels of efficiency, the alternative specification renders an insignificant coefficient. Thus, the evidence of spill-over effects is somewhat limited.

52. The direct effects of public and foreign ownership are investigated in the appendix. Relying on bank-level data, public ownership is found to be associated with a decrease in bank's own performance, while foreign ownership has a positive impact on bank's own efficiency. Foreign banks are likely to benefit from extra expertise from abroad parent companies, but the theory according to which national markets directly benefit from a knowledge spill over is not supported for the period and the countries included in this analysis.

53. Finally, market concentration does not have a significant impact on banks efficiency. Concentration of the banking market entails two opposing effects: more efficient banks are more likely to gain market shares over their less efficient counterparts, resulting in higher concentration and efficiency. However, the increase in concentration may reduce competitive behaviour and lessen incentives on efficiency gains. In the long-run, it is hard to determine which of the two effects of concentration dominates at the national market level. Figure 11 shows a slightly positive relation between efficiency and concentration for the period 2004-11. However, the relation is weak ${ }^{5}$ : some good performers have concentrated markets (Korea), while the opposite is also true (Peru, South Africa). In this sense, evaluating the differences in contestability across countries, rather than concentration (Berger et al., 2004), as it is probably a leading variable for technical efficiency, might be a more suitable test (see below).

5 The R-squared is equal to $8.7 \%$ if one tries to evaluate the linear relation between technical efficiency and concentration of commercial banking markets. 
Figure 12. Concentration and Efficiency, 2004 - 2011

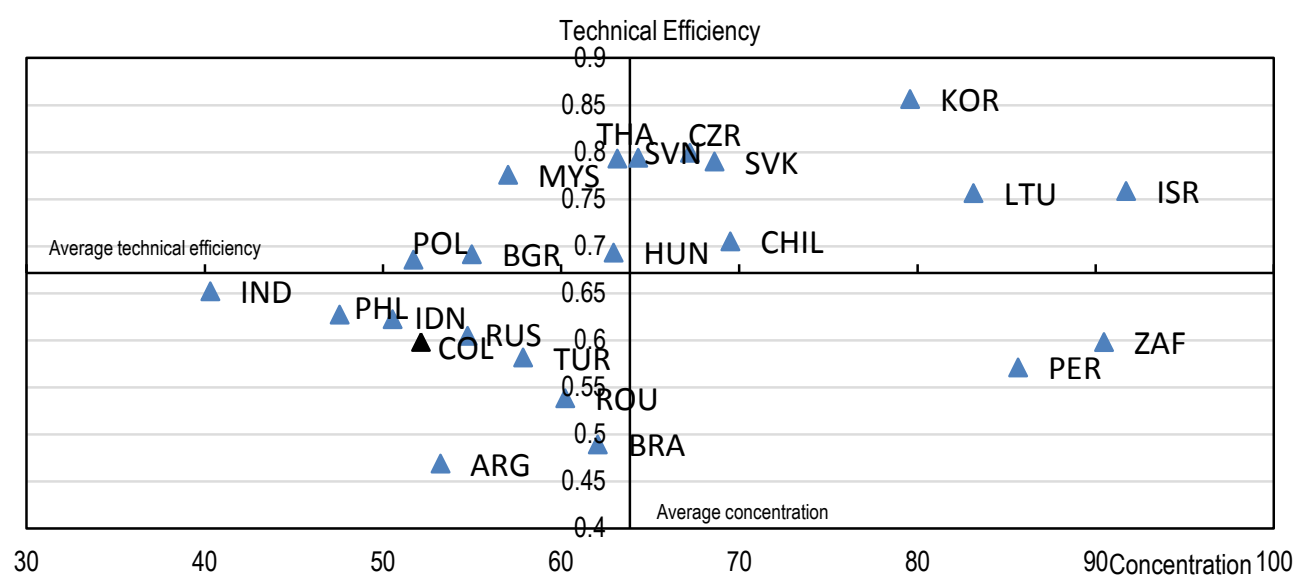

Notes: Technical efficiency is the average of the cost efficiency estimates from the stochastic frontier and data envelopment analyses for the period 2004-2011. Concentration is measured as the share of assets detained by the five largest banks of the national banking sector. The represented value is the average of the three point estimates from the World Bank Survey on Financial Regulations (2003, 2007, 2011).

Source: Authors' calculations based on data from Bloomberg, SNL Financial and World Bank Survey on Financial Regulations.

54. The Colombian banking sector has been found to have an intermediate level of cost/technical efficiency. The analysis of cost efficiency determinants confirms that the high intermediation cost in Colombia is partly stemming from an efficiency gap. The strength of the supervisory authority, as well as the degree to which commercial can engage in securities, insurance and real estate activities, are found to have significant effects on efficiency. However, unmeasured factors might play a primordial role in determining differences across countries. Contestability is certainly one of them. What is the competitive structure of the Colombian banking market? Is the Colombian market in a state of monopolistic or perfect competition? To learn about the competitive structure in which Colombian banks operate, the $\mathrm{H}$-statistic is a useful tool.

\section{Competition and contestability in the Colombian banking market}

55. Cost efficiency generally is influenced by the level of contestability. A more contestable market put pressure on banks, which normally react by increasing their efficiency. To determine the degree of competition in the Colombian banking system, an econometric model of contestability is estimated for each country in our sample. The Colombian banking sector is found to be in a monopolistic competition setting, with a higher degree of monopolistic power than most benchmark countries in the sample. Furthermore, there seems to be a slight upward trend in monopolistic power in the recent years. This could hold back gains in efficiency since a positive relation between efficiency and contestability is also found. Finally, market structures and regulations are found to have a significant impact on contestability.

\section{International comparison of banking sector competitiveness structures}

56. This paper follows the methodoloy of Panzar and Rosse (1987) to compute an contestability index for a given market. Under the assumptions that firms' cost functions are homogeneous in input prices and that they operate in a symmetric long-run equilibrium, these authors show that the sum of factor price elasticities of the revenue function is equal to one in case of competitive equilibrium, while it must be zero 
in case of a monopoly (or perfect cartel) ${ }^{6}$. Under monopolistic competition, the $\mathrm{H}$-statistic - defined as the sum of factor price elasticities is an index measuring the degree of contestability - is between 0 and 1 . To put it differently, the magnitude of $\mathrm{H}$ can be interpreted as an inverse measure of the degree of monopolistic power. This methodology is applied to each banking system of the countries included in the sample assuming the following functional form:

$\ln \left(p_{i t}^{y}\right)=\alpha_{i}+\sum_{j=1}^{3} \beta_{j} \ln \left(p_{i t}^{j}\right)+\sum_{j} \theta_{j} B S F_{i t}+$ macroeconomic factors $+v_{i t}(5)$

$p^{1}=\frac{\text { personnel expenses }}{\text { total assets }}$, proxy for price of labour

$p^{2}=\frac{\text { operating expenses }- \text { personnel expenses }}{\text { total assets }}$, proxy for price of equipment

$p^{3}=\frac{\text { interest expenses }}{\text { total liabilities }}$, proxy for the price of fundings

$p^{y}=\frac{\text { interest income }}{\text { total assets }}$, proxy for the price of bank output

$\alpha_{i}$ represents banks' fixed effects 
57. The bank fixed effects capture long-lasting differences in managerial capacities that could affect banks' performances. Following Levy Yeyati and Micco (2007) bank specific factors (fundamentals) that could impact interest incomes without going through the price mechanism are also included. To control for differences in risk taking and capital utilization, equity to assets, loans to deposits and earning assets to total assets ratios are considered. By dividing interest income by total assets, the effects of size on interest revenues are controlled. To take into account variations in country-specific macroeconomic factors that could have influenced banks' performances, the ratio of non-performing loans (capturing variations in risk premiums stemming from differences in loan quality) and GDP growth (proxy for the overall state of the economy) are included in the regressions. Finally, one should also consider the exchange rate of the local currency to US dollars as a control variable. For Latin American countries, these variations have been substantial, with potential impacts on banks' profits coming from operations in dollars. The estimation results by country are reported in Table A.4

58. According to the estimates, Colombian banks operate in a monopolistic competition setting. With an $\mathrm{H}$-statistic slightly below 0.6, Colombia ranks relatively well among the six Latin American countries included in our sample, although significantly behind Chile. When testing the hypotheses of perfect competition and perfect cartel are tested, for Colombia, both hypotheses are rejected at standard levels of significance (see Table A.5). Competition in the Colombian market is below the average of the nine OECD countries included in the sample (Figure 13, Panel A).

Figure 13. H-Statistic panel $2004-2013$
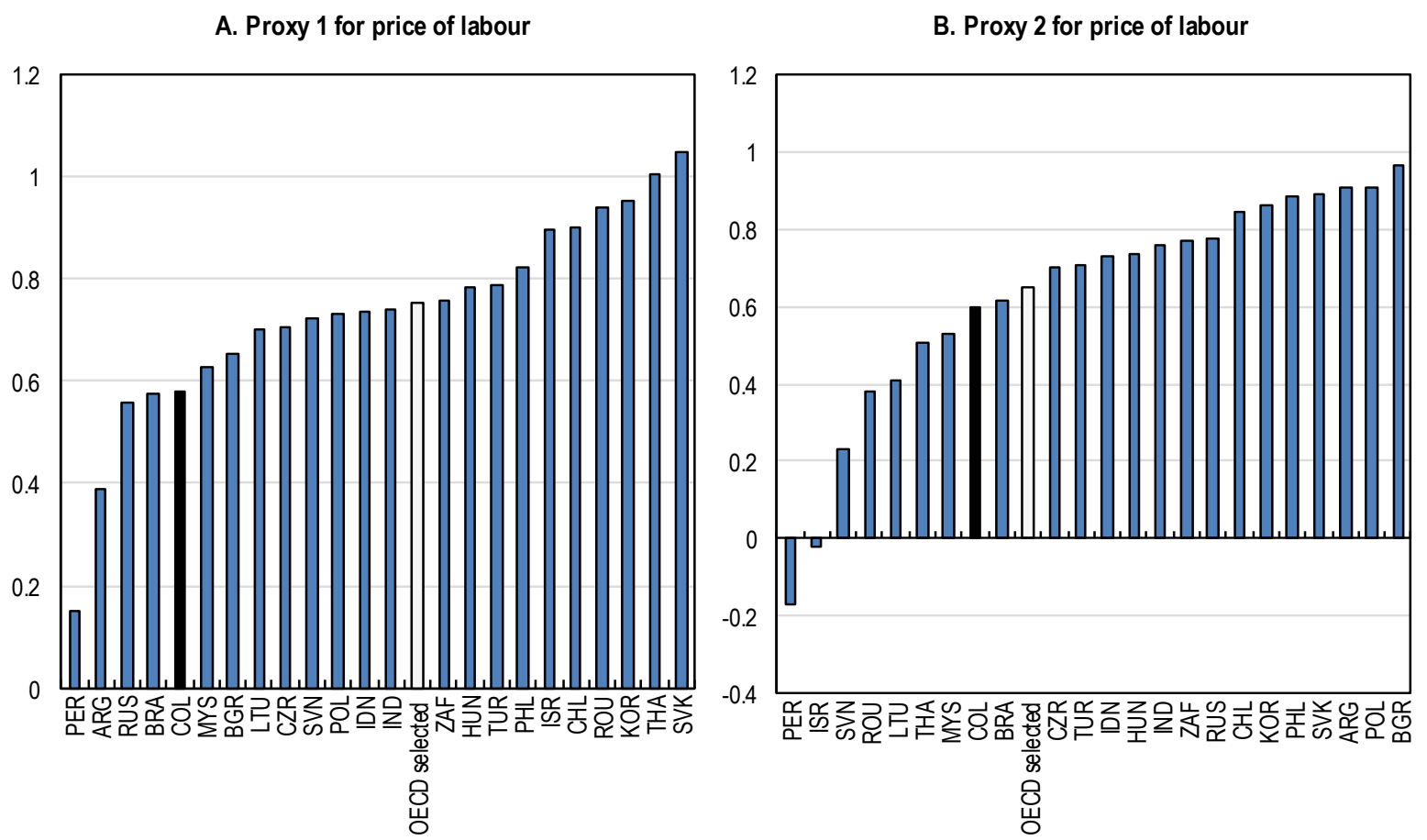

Note 1: proxy 1 for price of labour = labour expenses/total assets, proxy 2 for price of labour = labour expenses/number of employees

2: The $\mathrm{H}$-statistic captures the elasticity of bank interest revenues to input prices. The $\mathrm{H}$-statistic is equal to one in case of perfect competition, while it ranges between 0 and 1 in monopolistic competition. Below 0 , the $\mathrm{H}$-statistic highlights a monopoly (perfect cartel) situation.

Source: Authors' calculations based on data from Bloomberg, SNL Financial 
59. Despite significant variations is the relative ranking of countries when considering the alternative proxy for the price of labour, for the case of Colombia, the H-index is very stable, as well as its relative position (Figure 12, Panel B; Table A.6). While in the first specification Colombia ranks $19^{\text {th }}$, in the second one it ranks $16^{\text {th }}$. Again, the hypothesis of a monopolistic competition structure with an intermediate level of monopolistic power for Colombian banks appears to be confirmed, a perfect cartel or perfect competition can be rejected at standard confidence levels (Table A.7).

60. A series of robustness tests presented in the Appendix, include estimating input price elasticities without control variables using labour expenses over number of assets or using the number of employees as a proxy for the price of labour. They all tend to confirm that Colombia H-statistic is around 0.6, below the level of competition achieved on average in the OECD countries included in the sample.

\section{Evolution of contestability in Colombia}

61. To deepen the analysis of the Colombian banking sector, a dataset including yearly observations of all banks operating in Colombia from 2004 to 2013 - released by the Colombian authorities - is used. The reason why this data was not used for international comparisons is that they are not standardised in the same way as the SNL and Bloomberg data. Hence, there might be a risk of bias due to differences in accounting principles. However, this dataset is useful to evaluate the evolution of contestability in Colombia. Two different methods are employed to assess whether the degree of contestability has increased, decreased, or stayed steady. First, the H-statistic based on equation (5) is estimated for two subperiods of the sample: 2004-08 and 2009-13. The H-statistic for the first period is equal to 0.96, while it was equal to 0.67 in the second one (Table A.10). This approach shows evidence of a decline in contestability in Colombia. A parametric approach by Bikker and Spierdijk (2008) can be used to test this formally. In this case, the reduced form of the price equation is expressed the following way:

$$
\ln \left(p_{i t}^{y}\right)=\alpha+\exp (\tau \times \text { time })\left(\sum_{j=1}^{3} \beta_{j} \ln \left(p_{i t}^{j}\right)\right)+\sum_{j} \theta_{j} B S F_{i t}+v_{i}(6)
$$

$p^{1}=\frac{\text { personnel expenses }}{\text { total assets }}$

$p^{2}=\frac{\text { administrative expenses and depreciations }- \text { personnel expenses }}{\text { total assets }}$

$p^{3}=\frac{\text { interest expenses }}{\text { total liabilities }}$

$p^{y}=\frac{\text { interest income }}{\text { total assets }}$

62. This specification helps to avoid erratic changes in the H-statistic that appear when trying to evaluate its value on a yearly basis. Such variations are not consistent with the interpretation of the Hstatistic as an index of market contestability, as it seems natural to expect some rigidity and slow adjustment in market structure. For example, it takes time for a market to go from a perfect competition structure to a perfect cartel one. The $\tau$ coefficient captures the slow transition between competitive states. A time dependent $\mathrm{H}$-statistic is obtained:

$$
H(\text { time })=\left(\beta_{1}+\beta_{2}+\beta_{3}\right) \exp (\tau \times \text { time })
$$

63. When $\tau=0$, the competitive structure is constant over time, while $\tau<0$ (respectively $\tau>0$ ) indicates a decrease (increase) in competitiveness. The model based on equation (6) is evaluated by means of non-linear least squares; results are presented in Table A.11. To test the hypothesis of a decrease in competitiveness in the past decade for Colombian banks ${ }^{7}$, a one-sided t-test is considered. The null

$\mathrm{H} 0: \tau \geq 0 \mathrm{H} 1: \tau<0$ 
hypothesis is strongly rejected, confirming more formally the result that the Colombian banking sector has moved to a lower level of contestability in the past ten years.

\section{Links between contestability and efficiency}

64. More contestable markets are usually thought to promote efficiency. When barriers to entry and exit are lower, the competitive behaviour of firms is fostered. The available empirical evidences seem to validate this causal relationship between contestability and efficiency gains (Berger and Hannan, 1998).

65. Figure 14 illustrates the positive correlation between market contestability and efficiency for the sample of countries used in this paper. It divides the contestability-efficiency plan into four quadrants to represent countries, which are above or below average with respect to the two dimensions over the period 2004-13. It shows that countries above average in terms of contestability for 2004-13 are also more likely to be above average in terms of efficiency. In the top-right quadrant, countries such as South Korea, the Slovak Republic, and Israel have more contestable and efficient banking markets than the sample average. Colombia is located in the bottom-left quadrant, presenting a below average performance in terms of contestability and efficiency.

Figure 14. Contestability and Efficiency, panel 2004-2013

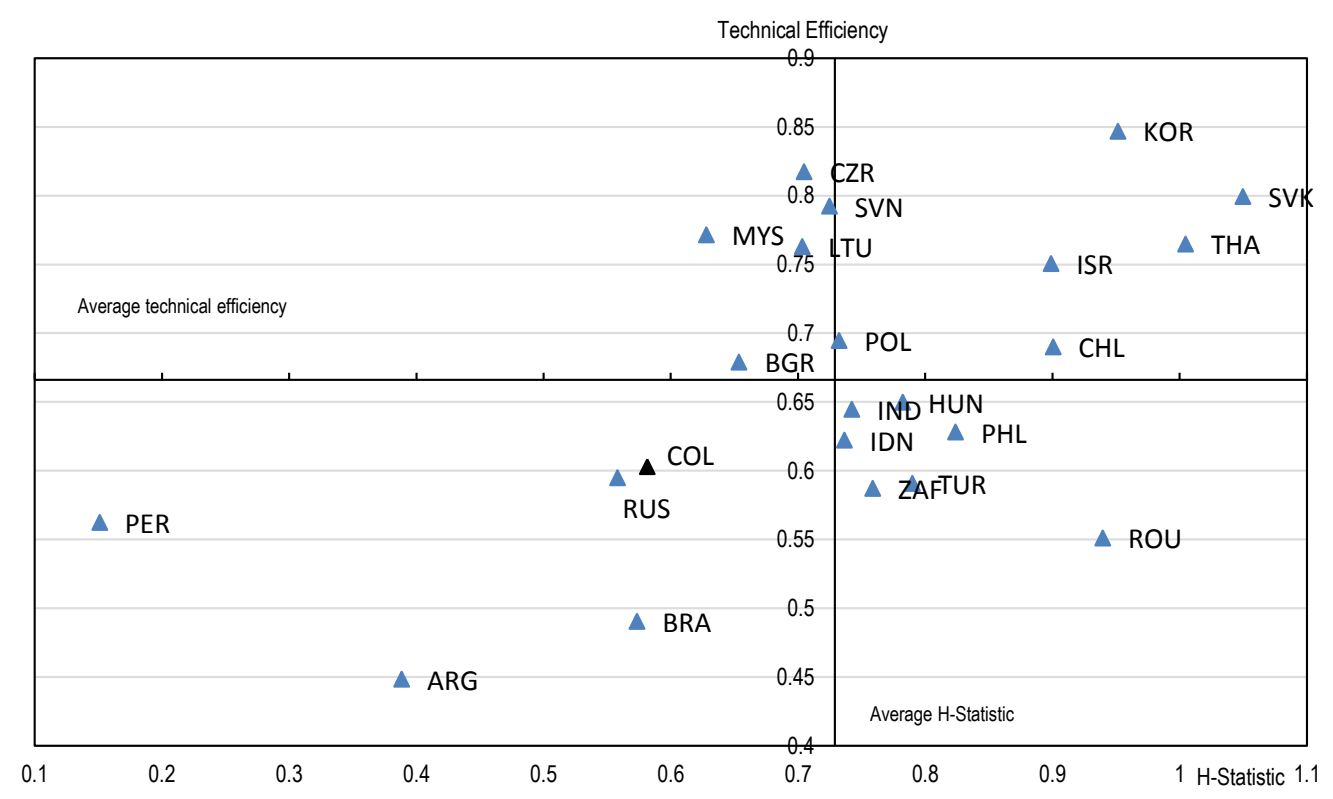

Note 1: Contestability is captured by the $\mathrm{H}$-statistic, measured using specification (1). Technical efficiency is the average of the estimates from the stochastic frontier and data envelopment analyses for the period 2004-2013

Source: raw data from Bloomberg and SNL Financial

\section{Determinants of market contestability}

66. This section explores the determinants of market contestability. To do so, time-varying H-indices by country and by year $\left(H_{i t}\right)$ are obtained using equation (6) separately for each country along the period 2004-13. Then, these $\mathrm{H}$-indices are regressed on a set of explanatory variables using countries' fixed effects. To allow for robustness tests, $\mathrm{H}$-indices were estimated with and without control variables in equation (6), and equation (7) was evaluated with and without time dummies. 


$$
H_{i t}=\alpha_{i}+\sum_{j=1}^{n} \beta_{j} \times x_{j i t}+u_{i t}
$$

67. The explanatory variables are the country-specific variables that were previously introduced to explain variations in inefficiency: i) the power of the official supervisory authority; ii) the degree to which banks face restrictions when engaging in securities, insurance and real estate operations; iii) the concentration of the national banking market, and iv) the market share of public as well as foreign-held banks.

Table 4. Determinants of contestability

\begin{tabular}{|c|c|c|c|c|c|c|c|c|}
\hline Model & (1) & $(2)$ & (3) & (4) & (5) & (6) & (7) & (8) \\
\hline \multicolumn{9}{|c|}{ Explanatory variables for H-Statistics } \\
\hline $\begin{array}{l}\text { Supervisory } \\
\text { power }\end{array}$ & $\begin{array}{l}-0.196 \\
(0.172)\end{array}$ & $\begin{array}{l}-0.002 \\
(0.164)\end{array}$ & $\begin{array}{c}0.003 \\
(0.142)\end{array}$ & $\begin{array}{c}0.093 \\
(0.135)\end{array}$ & $\begin{array}{l}-0.057 \\
(0.189)\end{array}$ & $\begin{array}{c}0.018 \\
(0.196)\end{array}$ & $\begin{array}{c}0.034 \\
(0.155)\end{array}$ & $\begin{array}{c}0.060 \\
(0.160)\end{array}$ \\
\hline $\begin{array}{l}\text { Activity } \\
\text { restrictions }\end{array}$ & $\begin{array}{c}0.576^{\star \star \star} \\
(0.189)\end{array}$ & $\begin{array}{c}0.173 \\
(0.192)\end{array}$ & $\begin{array}{l}0.309^{*} \\
(0.157)\end{array}$ & $\begin{array}{c}0.041 \\
(0.164)\end{array}$ & $\begin{array}{c}0.667^{\star \star \star} \\
(0.208)\end{array}$ & $\begin{array}{l}0.511^{* *} \\
(0.229)\end{array}$ & $\begin{array}{l}0.430^{\star *} \\
(0.171)\end{array}$ & $\begin{array}{c}0.321 \\
(0.194)\end{array}$ \\
\hline $\begin{array}{l}\text { Market } \\
\text { concentration }\end{array}$ & $\begin{array}{l}-0.124^{\star *} \\
(0.054)\end{array}$ & $\begin{array}{l}-0.099^{*} \\
(0.050)\end{array}$ & $\begin{array}{l}-0.062^{*} \\
(0.033)\end{array}$ & $\begin{array}{l}-0.055^{\star} \\
(0.031)\end{array}$ & $\begin{array}{c}-0.120^{\star *} \\
(0.059)\end{array}$ & $\begin{array}{l}-0.110^{*} \\
(0.060)\end{array}$ & $\begin{array}{l}-0.063^{*} \\
(0.035)\end{array}$ & $\begin{array}{l}-0.058 \\
(0.037)\end{array}$ \\
\hline $\begin{array}{l}\text { Public banks } \\
\text { share }\end{array}$ & $\begin{array}{c}-0.094^{\star \star} \\
(0.043)\end{array}$ & $\begin{array}{l}-0.086^{\star *} \\
(0.040)\end{array}$ & $\begin{array}{l}-0.046 \\
(0.038)\end{array}$ & $\begin{array}{l}-0.046 \\
(0.035)\end{array}$ & $\begin{array}{c}-0.163^{\star * *} \\
(0.047)\end{array}$ & $\begin{array}{c}-0.160^{\star * *} \\
(0.048)\end{array}$ & $\begin{array}{l}-0.095^{\star *} \\
(0.041)\end{array}$ & $\begin{array}{l}-0.094^{* *} \\
(0.042)\end{array}$ \\
\hline $\begin{array}{l}\text { Foreign banks } \\
\text { share }\end{array}$ & $\begin{array}{l}0.096^{*} \\
(0.053)\end{array}$ & $\begin{array}{l}0.129^{* *} \\
(0.050)\end{array}$ & $\begin{array}{l}0.086^{\star *} \\
(0.042)\end{array}$ & $\begin{array}{l}0.095^{* *} \\
(0.039)\end{array}$ & $\begin{array}{c}-0.03 \\
(0.058)\end{array}$ & $\begin{array}{l}-0.018 \\
(0.059)\end{array}$ & $\begin{array}{l}-0.010 \\
(0.045)\end{array}$ & $\begin{array}{l}-0.008 \\
(0.046)\end{array}$ \\
\hline $\begin{array}{l}\text { Control } \\
\text { variables in (6) }\end{array}$ & yes & yes & yes & yes & no & no & no & no \\
\hline $\begin{array}{l}\text { Interpolation } \\
\text { technique for } \\
\text { World Bank } \\
\text { Survey data }\end{array}$ & linear & linear & polynomial & polynomial & linear & linear & polynomial & polynomial \\
\hline $\begin{array}{l}\text { Time fixed } \\
\text { effects in (7) }\end{array}$ & no & yes & no & yes & no & yes & no & yes \\
\hline R-squared & 0.176 & 0.323 & 0.110 & 0.257 & 0.160 & 0.186 & 0.109 & 0.124 \\
\hline $\begin{array}{l}\text { Number of } \\
\text { countries }\end{array}$ & 20 & & & & & & & \\
\hline $\begin{array}{l}\text { Number of } \\
\text { observations }\end{array}$ & 160 & & & & & & & \\
\hline
\end{tabular}

68. While the strength of the supervisory authority is found to be positively correlated with efficiency, it has no clear effect on contestability (Table 4). Using a different approach and sample, Ahrend et al., (2009) find that more power for the banking supervisory is associated with greater competition in OECD economies. A potential source of difference is probably that the degree of enforcement of regulations is weaker in emerging market economies. Therefore, legal regulations per se might have a weaker effect in this context. However, the results show that activity restrictions are positively related to market contestability. This result is robust to variations in specifications and statically significant. One reason may be that when commercial banks are limited in their range of activities, they face fewer opportunities create barriers to competition by bundling services.

69. Market concentration has an adverse effect on contestability. This result is robust to variations in specifications and statically significant. When assets are detained by fewer banks, collusive behaviours are 
usually thought to be easier to maintain. Further, increases in concentration may deter possible competitors by increasing the cost of entry (Kessides, 1990), which could contribute to decrease contestability.

70. The market share of public banks also has a deterrent effect on contestability. Public banks are generally perceived as less sensitive to market pressure, and conversely to be less prone to compete for market shares than their private banks counterparts. Further, entering a market where opponents are supported by the government may be perceived as less profitable for outsiders, reducing incentives for new entries. The result is statistically significant and robust to variations in specifications. However, the result could also be driven by an omitted variable. For example, public banks might take into consideration other factors than profit maximization, such as correcting market failures, which may results in a lower sensitivity to market prices. This could contribute to the negative variation in contestability as measured by the H-statistic.

71. Foreign participation is positively correlated and statically significant with an increase in contestability in four out of the eight regressions performed. In the remaining estimations, the impact of foreign participation is small and non-significant. This somewhat weak result is consistent with the literature that finds different effects of foreign banks on contestability. For example, while Levy Yeyati and Micco (2007) find a negative relation, other studies point out a positive effect (Yildirim and Philippatos, 2007).

72. To sum up, the H-statistic underlies a state of monopolistic competition for the Colombian banking sector, with a degree of monopolistic power more elevated than OECD countries. Using a dataset that includes all the commercial banks in Colombia, a decreasing trend in competitiveness over the past ten years is evidenced. A positive correlation between contestability and efficiency is empirically observable for the national commercial banks included in the sample, which seems to suggest that the efficiency gap observed between Colombia and OECD members could be reduced by implementing and enforcing legislations improving contestability.

\section{Conclusions}

73. The analysis in this paper has estimated the influence of regulative and structural characteristics on commercial banks efficiency or contestability. A positive relation between contestability end efficiency has been found for the commercial banking systems included in the sample. Based on this analysis, some characteristics that are likely to improve efficiency directly or indirectly (through an increase in contestability) can be identified. Table 5 offers a synthesis of the influence that the different variables have as well as their level of statistical significance.

Table 5. Impact of structural and regulative characteristic on efficiency and contestability

\begin{tabular}{|l|l|l|}
\hline & Efficiency & Contestability \\
\hline Supervisory Power & + & + \\
Activity restrictions & $\left(^{*}\right)$ & + \\
& $\left(^{* *}\right)$ & + \\
Bank concentration & $\left.0^{*}\right)$ \\
\% government-held banks & - & - \\
\% foreign-held banks & $\left(^{* * *}\right)$ & $\left(^{*}\right)$ \\
\hline
\end{tabular}

Notes: + (-) sign indicates that a positive (negative) effects on efficiency/contestability has been identified in more than $50 \%$ of the reported estimations. ${ }^{\circ}$ indicates that no clear effect has been identified. ${ }^{* * *} p<0.01,{ }^{* *} p<0.05,{ }^{*} p<0.1$ in more than $50 \%$ of the reported estimations 
74. There are some signs pointing in the same direction in three cases - indicating that forces at play are complementary.

- The power of the supervisory agency of the banking sector tends to increase both efficiency and contestability, even if the statistical significance in the last case is not ensured. This result is coherent with other studies (Ahrend et al., 2009) that also found that an increase in the strength of supervisor was associated with greater contestability. By enforcing a better monitoring of banking activities, the supervisory agency is fostering efficiency indirectly (by enforcing competitive-friendly legislations) and directly (by avoiding illegal practices that may deter efficiency gains in the long-run). However, some authors point out that when corruption is a concern, a powerful supervisor may have the opposing effect on efficiency by hindering good practices through bribery and political connections (Barth et al., 2012). Hence, an increase in the supervisory authority power and anti-corruption measures are probably inseparable to achieve effective results.

- Activity restrictions have a positive effect on efficiency and contestability. It could be expected that such restrictions could be harmful for efficiency since potential economies of scope and complementarities might help reduce costs. However, these economies of scope and complementarities are apparently outweighed by the loss incurred in non-specialisation, and the decrease in contestability stemming from the creation of conglomerates more likely to enjoy market power.

- The market share of public banks has a deterrent effect on both contestability and efficiency. Public banks are sometimes thought to be less efficient than their private counterparts ${ }^{8}$, and less likely to compete for market share. This could reduce aggregate efficiency and market contestability. However, public banks in some market niches are justified when market failures are identified. For instance public bank and government-controlled trust companies in Colombia have been found to perform a public role in the financial markets by conducting operations in areas in which private banks are unwilling to enter (Eslava et al., 2012).

75. The concentration of the banking sector is one example where a potential trade-off can be identified. Efficient banks are more likely to gain market shares over than less competitive counterparts, resulting in higher aggregate efficiency. However, more concentration tends to reduce contestability, which in turns has a deterrent effect on efficiency gains. The resulting force is ambiguous, which may explain why no direct effect of concentration could be observed. Besides, it is likely that the final result depends on the level of concentration achieved. The deterrent effects of concentration on contestability are more likely to be important at high levels of concentration ${ }^{9}$. Hence, at low levels, the first effect - efficient banks taking over their less efficient counterparts - might dominate the loss incurred from contestability reduction, while the opposite is probably true at high level of concentration.

8. This point is analysed in the appendix.

9 When a quadratic term for concentration was included in equation (7), the corresponding estimate was negative in the 8 regressions represented in table 4 , but not statistically significant $(\mathrm{p}<0.1)$ in six of them. 


\section{REFERENCES}

Ahrend R., J. Arnold and F Murtin (2009), "Prudential Regulation and Competition in Financial Markets", OECD Economics Department Working Papers, No. 735, OECD Publishing.

Aigner, D., C.A. Lovell and P. Schmidt (1977), "Formulation and Estimation of Stochastic Frontier Production Function Models", Journal of Econometrics, No. 6, pp. 21-37.

Barajas, A., S. Roberto and N. Salazar (1999), "Interest Spreads in Banking in Colombia, 1974-96", IMF Staff Papers, Vol.46, No. 2, IMF, Washington, D.C.

Barth, J.R,, G. Caprio, R. Levine (2012), “The Evolution and Impact of Bank Regulations”, The World Bank, Policy Research Working Paper, 6288.

Battese, G.E. and T.J. Coelli (1992), "Frontier Production Functions, Technical Efficiency and Panel Data : With Application to Paddy Farmers in India", The Journal of Productivity Analysis, No.3, pp. 153169.

Battese, G.E and T.J. Coelli (1995), «A Model for Technical Ineffiency Effects in a Stochastic Frontier Production Function for Panel Data”, Empirical Economics, Vol. 20, Issue 2, pp. 325 - 332.

Beck, T, A, Demirrguc-Kunt and R. Levine (2000) "A New Database on Financial Development and Structure”, World Bank Economic Review, pp. 597-605, World Bank, Washington, D.C.

Beck, T., A. Demirguç-Kunt and R. Levine (2007) "Financial, Inequality and the Poor". Journal of Economic Growth 12(1), pp. 27-49.

Berger, A.N. and T.H. Hannan (1998) "The Efficiency Cost of Market Power in the Banking Industry: A Test of the 'Quiet Life' and Related Hypothesis", The Review of Economics and Statistics, MIT Press, Vol. 80(3), pages 454-465.

Berger, A.N., A. Demirguç-Kunt, R. Levine and J.G. Haubrich (2004) "Bank concentration and competition: An evolution in the making". Journal of Money, Credit, and Banking, Vol. 36 (3), pp. 434-450.

Bikker, J., L. Spierdijk (2008), "How Banking Competition Changed over Time", DNB Working Paper, No. 167

Bonin, John P., I. Hasan and P. Wachtel (2005) "Bank performance, efficiency and ownership in transition countries," Journal of Banking \& Finance, Elsevier, vol. 29(1), pp. 31-53.

Cihák, M., A. Demirguç-Kunt, E. Feyen and R. Levine (2012), "Benchmarking Financial Systems around the World”, Policy Research Working Paper, No. 6175, World Bank, Washington, D.C.

Claessens, S., S. Djankov (1999), "Ownership Concentration and Coporate Performance in The Czech Republic”, University of Michigan Business School Working Paper, No. 227.

Claessens, Stijn \& Van Horen, Neeltje, (2013). "Impact of Foreign Banks," Journal of Financial Perspectives, EY Global FS Institute, vol. 1(1), pages 29-42. 
Coelli, T.J. (1996), "A Guide to DEAP Version 2.1: A Data Envelopment (Computer) Program", University of New England, Department of Econometrics, Australia.

Coelli, T.J., D.S.R. Rao, C.J. O’Donnell and G.E. Battese (2005), “An Introduction to Efficiency and Production Analysis", Second Edition, Springer.

Cuartas, A., M. Rodríguez and N. Rodríguez (2012), "Banking Institutions in Colombia, consequence of a constant movement in Banking sector", Revista MBA EAFIT, p. 32-53.

Eslava, M., A. Maffioli, M. Meléndez (2012), "Second-tier Government Banks and Access to Credit. Micro-Evidence from Colombia", Inter-American Development Bank, Working Paper Series, No. 308 .

Farell, M.J. (1957), “The Measurement of Productive Efficiency”, Journal of the Royal Statistical Society. Series A (General), Vol. 120, No. 3, pp. 253-290.

Gómez-González, J.E. and N.M Kiefer (2007) "Bank failure: Evidence from the Colombian financial crisis”, OCC Economics Working Paper.

Greene, W. (2000) Econometric Analysis, Upper Saddle River, NJ: Prentice-Hall.

International Monetary Fund (2013), "Colombia: Financial System Stability Assessment”, IMF Country Report, No. 15/50, IMF, Washington, D.C.

Kessides, I. N. (1990) "Market Concentration, Contestability, and Sunk Costs", The Review of Economics and Statistics, Vol. 72, No. 4, pp. 614-622.

Kosak, M. and J. Zoric (2009), "Are there Any EU Membership-Related Efficiency Enhancements in Banking Sectors of the New EU Member States Detectable?", in Productivity in the Financial Services Sector, The European Money and Finance Forum, Vienna.

Levy Yeyati, E. and A. Micco (2007), "Concentration and foreign penetration in Latin American banking sectors: Impact on competition and risk", Journal of Banking and Finance, No. 31, pp. 1633-1647.

Luc Laeven and Fabián Valencia (2012), "Systemic Banking Crises Database: An Update”, IMF Working Paper WP/12/163

Meeusen, W. and J. van Den Broeck (1977), "Efficiency Estimation from Cobb-Douglas Production Functions with Composed Error”, International Economic Review, Vol. 18, No. 2, pp. 435-444.

Nikiel, E.M. and T.P. Opiela (2002), "Customer Type and Bank Efficiency in Poland: Implications for Emerging Market Banking”, Contemporary Economic Policy, Volume 20, Issue 3, pp. 255-271.

Panzar J.C. and J.N. Rosse (1987), "Testing for "Monopoly" Equilibrium", The Journal of Industrial Economics, Vol. 35, No. 4, The Empirical Renaissance in Industrial Economics, pp. 443-456.

Poghosyan, T. (2012), "Financial Intermediation Costs in Low-Income Countries: The Role of Regulatory, Institutional, and Macroeconomic Factors", IMF Working Paper 12/140.

Randal, R. (1998), "Interest Rate Spreads in the Eastern Caribbean", International Monetary Fund, Working Paper 98/59. 
Simar, L and P.W. Wilson (1998), "Sensitivity Analysis of Efficiency Scores: How to Bootstrap in Nonparametric Frontier Models", Management Science, No. 44(1), pp. 49 - 64.

Tabak, B.M., D.M. Fazio and D.O. Cajueiro (2011), "Profit, Cost and Scale Efficiency for Latin American Banks: concentration-performance relationship", Working Paper Series 244, Brazilian Central Bank.

Wang, H.J. and P. Schmidt (2002), "One-Step and Two-Step Estimation of the Effects of Exogenous Variables on Technical Efficiency Levels", Journal of Productivity Analysis, No. 18, 129-144.

Wezel, T. (2010), "Bank Efficiency amid Foreign Entry: Evidence from the Central American Region, International Monetary Fund, Working Paper, 10/95.

Yildirim, H. S. and G. C. Philippatos (2007), "Restructuring, consolidation and competition in Latin American banking markets", Journal of Banking and Finance, Vol. 31, Issue 3, pp. $629-639$. 


\section{APPENDIX}

Stochastic Frontier and Data Envelopment Analyses

Stochastic Frontier Analysis

Table A.1. SFA - proxy 1 for labour price - number of banks by year

\begin{tabular}{|l|lllllllllll|}
\hline Country & $\mathbf{2 0 0 4}$ & $\mathbf{2 0 0 5}$ & $\mathbf{2 0 0 6}$ & $\mathbf{2 0 0 7}$ & $\mathbf{2 0 0 8}$ & $\mathbf{2 0 0 9}$ & $\mathbf{2 0 1 0}$ & $\mathbf{2 0 1 1}$ & $\mathbf{2 0 1 2}$ & $\mathbf{2 0 1 3}$ & Total \\
\hline ARG & 5 & 7 & 7 & 7 & 7 & 7 & 15 & 16 & 16 & 14 & $\mathbf{1 0 1}$ \\
BGR & 3 & 6 & 5 & 6 & 7 & 7 & 14 & 14 & 14 & 9 & $\mathbf{8 5}$ \\
BRA & 15 & 19 & 19 & 20 & 20 & 18 & 37 & 39 & 38 & 30 & $\mathbf{2 5 5}$ \\
CHL & 6 & 6 & 6 & 6 & 6 & 6 & 14 & 14 & 14 & 14 & $\mathbf{9 2}$ \\
COL & 7 & 4 & 4 & 6 & 8 & 9 & 13 & 13 & 13 & 11 & $\mathbf{8 8}$ \\
CZR & 1 & 4 & 5 & 6 & 6 & 6 & 12 & 13 & 13 & 11 & $\mathbf{7 7}$ \\
HUN & 1 & 3 & 4 & 7 & 8 & 8 & 8 & 8 & 8 & 6 & $\mathbf{6 1}$ \\
IDN & 24 & 26 & 27 & 32 & 31 & 32 & 52 & 55 & 55 & 54 & $\mathbf{3 8 8}$ \\
IND & 30 & 33 & 35 & 37 & 39 & 41 & 43 & 47 & 47 & 45 & $\mathbf{3 9 7}$ \\
ISR & 5 & 7 & 8 & 8 & 8 & 8 & 9 & 9 & 9 & 9 & $\mathbf{8 0}$ \\
KOR & 3 & 3 & 3 & 19 & 19 & 21 & 18 & 15 & 23 & 23 & $\mathbf{1 4 7}$ \\
LTU & - & 3 & 3 & 5 & 5 & 5 & 6 & 6 & 5 & 5 & $\mathbf{4 3}$ \\
MYS & 10 & 10 & 11 & 23 & 23 & 22 & 40 & 41 & 42 & 37 & $\mathbf{2 5 9}$ \\
PER & 5 & 6 & 10 & 7 & 12 & 12 & 21 & 21 & 17 & 10 & $\mathbf{1 2 1}$ \\
PHL & 14 & 13 & 14 & 12 & 15 & 16 & 23 & 24 & 23 & 16 & $\mathbf{1 7 0}$ \\
POL & 6 & 10 & 12 & 15 & 15 & 15 & 19 & 19 & 17 & 15 & $\mathbf{1 4 3}$ \\
ROU & 3 & 7 & 7 & 9 & 9 & 8 & 13 & 14 & 11 & 5 & $\mathbf{8 6}$ \\
RUS & 12 & 16 & 17 & 28 & 34 & 38 & 42 & 40 & 39 & 28 & $\mathbf{2 9 4}$ \\
SVK & 4 & 4 & 4 & 4 & 6 & 6 & 8 & 8 & 7 & 4 & $\mathbf{5 5}$ \\
SVN & 2 & 2 & 5 & 5 & 5 & 5 & 11 & 11 & 10 & 6 & $\mathbf{6 2}$ \\
THA & 7 & 8 & 9 & 11 & 15 & 16 & 21 & 22 & 19 & 18 & $\mathbf{1 4 6}$ \\
TUR & 3 & 4 & 11 & 17 & 17 & 17 & 28 & 29 & 28 & 29 & $\mathbf{1 8 3}$ \\
ZAF & 3 & 3 & 4 & 5 & 5 & 5 & 13 & 13 & 12 & 11 & $\mathbf{7 4}$ \\
Total & $\mathbf{1 6 9}$ & $\mathbf{2 0 4}$ & $\mathbf{2 3 0}$ & $\mathbf{2 9 5}$ & $\mathbf{3 2 0}$ & $\mathbf{3 2 8}$ & $\mathbf{4 8 0}$ & $\mathbf{4 9 1}$ & $\mathbf{4 8 0}$ & $\mathbf{4 1 0}$ & $\mathbf{3 4 0 7}$ \\
\hline
\end{tabular}


Table A.2 SFA - proxy 2 for labour price- number of banks by year

\begin{tabular}{|l|lllllllllll|}
\hline Country & $\mathbf{2 0 0 4}$ & $\mathbf{2 0 0 5}$ & $\mathbf{2 0 0 6}$ & $\mathbf{2 0 0 7}$ & $\mathbf{2 0 0 8}$ & $\mathbf{2 0 0 9}$ & $\mathbf{2 0 1 0}$ & $\mathbf{2 0 1 1}$ & $\mathbf{2 0 1 2}$ & $\mathbf{2 0 1 3}$ & Total \\
\hline ARG & 3 & 4 & 4 & 4 & 4 & 5 & 8 & 8 & 10 & 9 & $\mathbf{5 9}$ \\
BGR & 2 & 4 & 4 & 4 & 5 & 6 & 14 & 14 & 14 & 8 & $\mathbf{7 5}$ \\
BRA & 7 & 10 & 14 & 15 & 12 & 13 & 21 & 21 & 24 & 18 & $\mathbf{1 5 5}$ \\
CHL & 3 & 3 & 4 & 2 & 3 & 5 & 10 & 10 & 11 & 11 & $\mathbf{6 2}$ \\
COL & 3 & 2 & 2 & 5 & 8 & 9 & 13 & 13 & 13 & 11 & $\mathbf{7 9}$ \\
CZR & 1 & 4 & 5 & 6 & 6 & 6 & 11 & 12 & 12 & 10 & $\mathbf{7 3}$ \\
HUN & 1 & 2 & 3 & 7 & 8 & 8 & 8 & 8 & 8 & 6 & $\mathbf{5 9}$ \\
IDN & 24 & 26 & 26 & 32 & 31 & 32 & 50 & 52 & 52 & 51 & $\mathbf{3 7 6}$ \\
IND & 25 & 29 & 24 & 31 & 31 & 34 & 32 & 38 & 39 & 33 & $\mathbf{3 1 6}$ \\
ISR & 3 & 6 & 7 & 8 & 8 & 8 & 9 & 8 & 9 & 9 & $\mathbf{7 5}$ \\
KOR & 3 & 3 & 3 & 14 & 16 & 17 & 15 & 13 & 21 & 20 & $\mathbf{1 2 5}$ \\
LTU & - & 3 & 3 & 5 & 5 & 5 & 6 & 5 & 4 & 4 & $\mathbf{4 0}$ \\
MYS & 9 & 10 & 7 & 12 & 12 & 11 & 14 & 12 & 10 & 9 & $\mathbf{1 0 6}$ \\
PER & 5 & 5 & 7 & 7 & 6 & 6 & 15 & 17 & 15 & 7 & $\mathbf{9 0}$ \\
PHL & 13 & 10 & 12 & 8 & 10 & 13 & 13 & 15 & 15 & 9 & $\mathbf{1 1 8}$ \\
POL & 1 & 9 & 10 & 10 & 11 & 13 & 18 & 18 & 16 & 15 & $\mathbf{1 2 1}$ \\
ROU & 3 & 7 & 7 & 9 & 8 & 7 & 13 & 14 & 11 & 5 & $\mathbf{8 4}$ \\
RUS & 7 & 11 & 10 & 18 & 23 & 28 & 27 & 25 & 26 & 13 & $\mathbf{1 8 8}$ \\
SVK & 4 & 4 & 4 & 4 & 6 & 6 & 8 & 8 & 7 & 4 & $\mathbf{5 5}$ \\
SVN & 2 & 2 & 5 & 5 & 5 & 5 & 11 & 11 & 10 & 6 & $\mathbf{6 2}$ \\
THA & 7 & 7 & 9 & 9 & 9 & 8 & 11 & 12 & 11 & 11 & $\mathbf{9 4}$ \\
TUR & 2 & 3 & 7 & 12 & 15 & 14 & 24 & 25 & 25 & 22 & $\mathbf{1 4 9}$ \\
ZAF & 3 & 3 & 4 & 4 & 5 & 5 & 10 & 10 & 10 & 10 & $\mathbf{6 4}$ \\
Total & $\mathbf{1 3 1}$ & $\mathbf{1 6 7}$ & $\mathbf{1 8 1}$ & $\mathbf{2 3 1}$ & $\mathbf{2 4 7}$ & $\mathbf{2 6 4}$ & $\mathbf{3 6 1}$ & $\mathbf{3 6 9}$ & $\mathbf{3 7 3}$ & $\mathbf{3 0 1}$ & $\mathbf{2 6 2 5}$ \\
\hline
\end{tabular}


Data Envelopment Analysis

Table A.3 DEA - yearly estimates of VRS TE

\begin{tabular}{|l|lllllllllll|}
\hline Country & $\mathbf{2 0 0 4}$ & $\mathbf{2 0 0 5}$ & $\mathbf{2 0 0 6}$ & $\mathbf{2 0 0 7}$ & $\mathbf{2 0 0 8}$ & $\mathbf{2 0 0 9}$ & $\mathbf{2 0 1 0}$ & $\mathbf{2 0 1 1}$ & $\mathbf{2 0 1 2}$ & $\mathbf{2 0 1 3}$ & $\begin{array}{c}\text { Average } \\
\mathbf{2 0 0 4 - 2 0 1 3}\end{array}$ \\
\hline ARG & 0.29 & 0.31 & 0.29 & 0.26 & 0.25 & 0.22 & 0.18 & 0.19 & 0.13 & 0.09 & $\mathbf{0 . 1 9}$ \\
BGR & 0.45 & 0.51 & 0.66 & 0.66 & 0.69 & 0.53 & 0.48 & 0.49 & 0.51 & 0.48 & $\mathbf{0 . 5 2}$ \\
BRA & 0.18 & 0.24 & 0.23 & 0.32 & 0.19 & 0.37 & 0.32 & 0.26 & 0.23 & 0.27 & $\mathbf{0 . 2 6}$ \\
CHL & 0.60 & 0.55 & 0.53 & 0.50 & 0.39 & 0.69 & 0.59 & 0.50 & 0.43 & 0.43 & $\mathbf{0 . 5 1}$ \\
COL & 0.29 & 0.35 & 0.35 & 0.34 & 0.33 & 0.32 & 0.39 & 0.44 & 0.34 & 0.34 & $\mathbf{0 . 3 6}$ \\
CZR & 0.48 & 0.78 & 0.93 & 0.84 & 0.81 & 0.83 & 0.78 & 0.81 & 0.81 & 0.81 & $\mathbf{0 . 8 1}$ \\
HUN & 0.77 & 0.55 & 0.70 & 0.45 & 0.47 & 0.44 & 0.43 & 0.41 & 0.37 & 0.40 & $\mathbf{0 . 4 5}$ \\
IDN & 0.42 & 0.42 & 0.41 & 0.43 & 0.48 & 0.46 & 0.38 & 0.41 & 0.43 & 0.42 & $\mathbf{0 . 4 3}$ \\
IND & 0.50 & 0.52 & 0.57 & 0.53 & 0.51 & 0.52 & 0.50 & 0.56 & 0.44 & 0.47 & $\mathbf{0 . 5 1}$ \\
ISR & 0.82 & 0.48 & 0.86 & 0.87 & 0.82 & 0.65 & 0.92 & 0.45 & 0.62 & 0.70 & $\mathbf{0 . 7 2}$ \\
KOR & 0.80 & 0.81 & 0.82 & 0.81 & 0.82 & 0.85 & 0.80 & 0.83 & 0.72 & 0.79 & $\mathbf{0 . 8 0}$ \\
LTU & - & 0.73 & 0.73 & 0.67 & 0.61 & 0.53 & 0.58 & 0.63 & 0.67 & 0.78 & $\mathbf{0 . 6 5}$ \\
MYS & 0.80 & 0.74 & 0.79 & 0.70 & 0.83 & 0.78 & 0.79 & 0.82 & 0.71 & 0.74 & $\mathbf{0 . 7 7}$ \\
PER & 0.37 & 0.40 & 0.33 & 0.35 & 0.53 & 0.57 & 0.35 & 0.38 & 0.38 & 0.37 & $\mathbf{0 . 3 9}$ \\
PHL & 0.43 & 0.49 & 0.47 & 0.49 & 0.60 & 0.52 & 0.49 & 0.54 & 0.52 & 0.48 & $\mathbf{0 . 5 0}$ \\
POL & 0.47 & 0.44 & 0.51 & 0.56 & 0.49 & 0.53 & 0.56 & 0.56 & 0.53 & 0.58 & $\mathbf{0 . 5 3}$ \\
ROU & 0.21 & 0.35 & 0.36 & 0.36 & 0.35 & 0.32 & 0.37 & 0.36 & 0.33 & 0.36 & $\mathbf{0 . 3 5}$ \\
RUS & 0.46 & 0.42 & 0.48 & 0.46 & 0.47 & 0.51 & 0.40 & 0.35 & 0.36 & 0.35 & $\mathbf{0 . 4 2}$ \\
SVK & 0.60 & 0.76 & 0.64 & 0.61 & 0.64 & 0.74 & 0.80 & 0.75 & 0.72 & 0.76 & $\mathbf{0 . 7 1}$ \\
SVN & 0.44 & 0.59 & 0.69 & 0.69 & 0.67 & 0.70 & 0.67 & 0.63 & 0.56 & 0.58 & $\mathbf{0 . 6 3}$ \\
THA & 0.91 & 0.89 & 0.71 & 0.68 & 0.79 & 0.73 & 0.71 & 0.63 & 0.57 & 0.53 & $\mathbf{0 . 7 0}$ \\
TUR & 0.24 & 0.33 & 0.37 & 0.40 & 0.34 & 0.41 & 0.40 & 0.39 & 0.37 & 0.38 & $\mathbf{0 . 3 8}$ \\
ZAF & 0.52 & 0.39 & 0.53 & 0.47 & 0.57 & 0.40 & 0.39 & 0.44 & 0.39 & 0.35 & $\mathbf{0 . 4 3}$ \\
\hline
\end{tabular}

\section{World Bank Survey on Financial Regulation}

\section{Box A.1. Official Supervisory Power - Survey 2011}

5.10 Does the banking supervisor have the right to meet with the external auditors and discuss their report without the approval of the bank?

a. No

b. Yes, it happens on a regular basis.

c. Yes, it happens on an exceptional basis.

5.9 Are auditors required to communicate directly to the supervisory agency any presumed involvement of bank directors or senior managers in illicit activities, fraud, or insider abuse?

5.12 In cases where the supervisor identifies that the bank has received an inadequate audit, does the supervisor have the powers to take actions against ...

b. The external auditor

a. The bank

12.3.2 Can the supervisory authority force a bank to change its internal organizational structure?

10.5 Do banks disclose to the supervisors ...?:

b. Off-balance sheet items 


\section{ECO/WKP(2015)21}
a. Full audited financial statements
c. Governance and risk management framework
d. Regulatory capital and capital adequacy ratio
e. Transactions with related parties

f. Any other material information (i.e. information which omission or misstatement could change or influence the assessment or decision of a user relying on that information for making decisions)

g. Scope of consolidation (including reasons for not including certain entities, where appropriate)"

11.1 Please indicate whether the following enforcement powers are available to the supervisory agency

f. Require banks to constitute provisions to cover actual or potential losses

a. Cease and desist-type orders for imprudent bank practices

b. Forbearance (i.e. to waive regulatory and supervisory requirements)

c. Require a bank to meet supervisory requirements (e.g. capital, liquidity etc.) that are stricter than the legal or regulatory minimum

d. Require bank to enhance governance, internal controls and risk management systems

e. Require bank to apply specific provisioning and/or write-off policies

g. Restrict or place conditions on the types of business conducted by bank

h. Withdraw the bank's license

i. Require banks to reduce/restructure their operations (e.g. via asset sales and branch closures) and adjust their risk profile

I. Suspend or remove bank directors

m. Suspend or remove managers

n. Require commitment/action from controlling shareholder(s) to support the bank with new equity (e.g. capital restoration plan)

$11.1 \mathrm{j}$. Require banks to reduce or suspend dividends to shareholders

$11.1 \mathrm{k}$. Require banks to reduce or suspend bonuses and other remuneration to bank directors and managers 11.5 Which authority has the powers to perform the following problem bank resolution activities?

Enter the initials of the corresponding authority from the following list of options: $B S=$ Bank Supervisor, $C=$ Court, DIA = Deposit Insurance Agency, BR/AMC = Bank Restructuring or Asset Management Agency, OTH = Other please specify).

a. Declare insolvency

Other - please specify

d. Undertake bank resolution mechanisms

Other - please specify

e. Appoint and oversee a bank liquidator/receiver

Other - please specify

11.5 b. Supersede shareholders' rights

Other - please specify

11.5 b. Supersede shareholders' rights

Other - please specify

$11.5 \mathrm{c}$. Remove and replace bank senior management and directors

Source : Bank Regulation and Supervision Survey 


\section{Box A.2 Activity restrictions on banking activities - Survey 2011}

4.1 What are the conditions under which banks can engage in securities activities?

a. A full range of these activities can be conducted directly in banks,

b. A full range of these activities are offered but all or some of these activities must be conducted in subsidiaries, or in another part of a common holding company or parent,

c. Less than the full range of activities can be conducted in banks, or subsidiaries, or in another part of a common holding company or parent,

d. None of these activities can be done in either banks or subsidiaries, or in another part of a common holding company or parent."

4.2 What are the conditions under which banks can engage in insurance activities?

a. A full range of these activities can be conducted directly in banks,

b. A full range of these activities are offered but all or some of these activities must be conducted in subsidiaries, or in another part of a common holding company or parent

c. Less than the full range of activities can be conducted in banks, or subsidiaries, or in another part of a common holding company or parent,

d. None of these activities can be done in either banks or subsidiaries, or in another part of a common holding company or parent"

4.3 What are the conditions under which banks can engage in real estate activities?

a. A full range of these activities can be conducted directly in banks,

b. A full range of these activities are offered but all or some of these activities must be conducted in subsidiaries, or in another part of a common holding company or parent

c. Less than the full range of activities can be conducted in banks, or subsidiaries, or in another part of a common holding company or parent

d. None of these activities can be done in either banks or subsidiaries, or in another part of a common holding company or parent

Source : Bank Regulation and Supervision Survey 
H-statistic

Table A.4. H-statistic, proxy 1 for labour price and control variables, main estimates

\begin{tabular}{|c|c|c|c|c|c|c|}
\hline Country & Price of Funds & Price of Equipment & Price of Labour & $\mathbf{H}$ & Observations & R-squared \\
\hline ARG & $0.431^{\star \star \star}$ & 0.0261 & -0.0684 & 0.39 & 101 & 0.89 \\
\hline BGR & $0.298^{\star * *}$ & 0.0568 & 0.299 & 0.65 & 85 & 0.61 \\
\hline BRA & $0.431^{* * *}$ & -0.00941 & 0.152 & 0.57 & 255 & 0.47 \\
\hline CHL & $0.516^{\star \star *}$ & 0.0827 & $0.302^{\star *}$ & 0.90 & 92 & 0.87 \\
\hline COL & $0.315^{\star *}$ & 0.0105 & 0.256 & 0.58 & 88 & 0.76 \\
\hline CZR & $0.340^{* \star *}$ & $0.165^{*}$ & $0.200^{* *}$ & 0.71 & 77 & 0.88 \\
\hline HUN & $0.466^{* * *}$ & -0.0195 & $0.336^{\star \star \star}$ & 0.78 & 61 & 0.86 \\
\hline IDN & $0.546^{* * *}$ & 0.0557 & $0.135^{\star \star \star}$ & 0.74 & 388 & 0.53 \\
\hline IND & $0.679^{* * *}$ & 0.0154 & $0.0480^{*}$ & 0.74 & 397 & 0.89 \\
\hline ISR & $0.341^{* * *}$ & 0.121 & 0.437 & 0.90 & 80 & 0.74 \\
\hline KOR & $0.766^{\star \star \star}$ & $0.0466^{*}$ & $0.139^{\star * *}$ & 0.95 & 151 & 0.98 \\
\hline LTU & $0.437^{\star \star \star}$ & 0.0796 & $0.187^{\star *}$ & 0.70 & 43 & 0.95 \\
\hline MYS & $0.480^{* * *}$ & $0.0676^{\star \star \star}$ & $0.0804^{* *}$ & 0.63 & 259 & 0.79 \\
\hline PER & $0.335^{\star \star *}$ & -0.0299 & -0.154 & 0.15 & 121 & 0.51 \\
\hline PHL & $0.283^{* * *}$ & $0.233^{\star *}$ & $0.308^{* *}$ & 0.82 & 170 & 0.49 \\
\hline POL & $0.650^{\star \star \star}$ & 0.0159 & 0.0665 & 0.73 & 143 & 0.71 \\
\hline ROU & $0.476^{\star \star \star}$ & 0.0176 & 0.446 & 0.94 & 86 & 0.76 \\
\hline RUS & $0.316^{\star * *}$ & 0.0533 & $0.189^{\star \star \star}$ & 0.56 & 294 & 0.76 \\
\hline SVK & $33.40 \%$ & -0.0361 & $0.752^{* *}$ & 1.05 & 55 & 0.65 \\
\hline SVN & $0.356^{* * *}$ & $-0.0871^{*}$ & $0.456^{\star \star \star}$ & 0.72 & 62 & 0.86 \\
\hline THA & $0.431^{* * *}$ & 0.0737 & $0.500^{\star \star \star}$ & 1.00 & 146 & 0.83 \\
\hline TUR & $0.572^{\star \star \star}$ & $0.0870^{* *}$ & $0.131^{* *}$ & 0.79 & 179 & 0.89 \\
\hline ZAF & $0.696^{* * *}$ & $0.0655^{*}$ & -0.00248 & 0.76 & 74 & 0.86 \\
\hline
\end{tabular}

Note: Price of labour price is measured as labour expenses divided by the total assets 
Table A.5. H-statistic, proxy 1 for labour price and control variables, hypothesis testing

\begin{tabular}{|l|cc|}
\hline Country & p-value perfect cartel & p-value perfect competition \\
\hline ARG & $8.5 \%$ & $3.9 \%$ \\
BGR & $0.0 \%$ & $1.1 \%$ \\
BRA & $0.0 \%$ & $0.0 \%$ \\
CHL & $0.0 \%$ & $12.0 \%$ \\
COL & $0.1 \%$ & $1.1 \%$ \\
CZR & $0.0 \%$ & $1.2 \%$ \\
HUN & $0.0 \%$ & $9.7 \%$ \\
IDN & $0.0 \%$ & $0.3 \%$ \\
IND & $0.0 \%$ & $0.0 \%$ \\
ISR & $0.3 \%$ & $67.7 \%$ \\
KOR & $0.0 \%$ & $11.4 \%$ \\
LTU & $0.0 \%$ & $3.0 \%$ \\
MYS & $0.0 \%$ & $0.0 \%$ \\
PER & $22.9 \%$ & $0.0 \%$ \\
PHL & $0.0 \%$ & $9.6 \%$ \\
POL & $0.0 \%$ & $0.3 \%$ \\
ROU & $0.0 \%$ & $74.8 \%$ \\
RUS & $0.0 \%$ & $0.0 \%$ \\
SVK & $0.0 \%$ & $69.6 \%$ \\
SVN & $0.0 \%$ & $0.0 \%$ \\
THA & $0.0 \%$ & $95.7 \%$ \\
TUR & $0.0 \%$ & $0.1 \%$ \\
ZAF & $0.0 \%$ & $2.9 \%$ \\
\hline
\end{tabular}

Perfect competition: (1) $\mathrm{H} 0: \mathrm{H}=1, \mathrm{H} 1: \mathrm{H} \neq 1$; perfect cartel (2) $\mathrm{H} \leq 0, \mathrm{H} 1: \mathrm{H}>0$ 
Table A.6. H-statistic, proxy 2 for price of labour and control variables, main estimates

\begin{tabular}{|c|c|c|c|c|c|c|}
\hline Country & Price of Funds & Price of Equipment & Price of Labour & $\mathbf{H}$ & Observations & R-squared \\
\hline ARG & $0.444^{\star * \star}$ & $0.281^{\star *}$ & 0.183 & 0.91 & 59 & 0.96 \\
\hline BGR & $0.492^{\star \star *}$ & 0.0813 & 0.391 & 0.96 & 75 & 0.60 \\
\hline BRA & $0.509^{* * *}$ & -0.00775 & 0.116 & 0.62 & 155 & 0.49 \\
\hline CHL & $0.508^{* \star *}$ & $0.238^{\star \star \star}$ & $0.0979^{* * *}$ & 0.84 & 62 & 0.93 \\
\hline COL & $0.472^{\star \star \star}$ & 0.0188 & 0.107 & 0.60 & 79 & 0.78 \\
\hline CZR & $0.347^{* \star *}$ & $0.252^{* * *}$ & 0.103 & 0.70 & 73 & 0.87 \\
\hline HUN & $0.555^{\star \star *}$ & 0.018 & 0.161 & 0.73 & 59 & 0.81 \\
\hline IDN & $0.551^{* * *}$ & $0.0977^{*}$ & $0.0814^{\star \star}$ & 0.73 & 376 & 0.53 \\
\hline IND & $0.656^{* * *}$ & $0.0419^{* *}$ & $0.0605^{* * *}$ & 0.76 & 316 & 0.89 \\
\hline ISR & $0.352^{* * *}$ & $0.222^{* *}$ & $-0.594^{\star \star \star}$ & -0.02 & 75 & 0.78 \\
\hline KOR & $0.715^{\star \star \star}$ & $0.101^{* *}$ & 0.0472 & 0.86 & 125 & 0.94 \\
\hline LTU & $0.428^{\star * *}$ & $0.227^{\star \star *}$ & $-0.247^{* * *}$ & 0.41 & 40 & 0.96 \\
\hline MYS & $0.469^{* * *}$ & 0.0582 & 0.000355 & 0.53 & 106 & 0.84 \\
\hline PER & $0.219^{\star * \star}$ & $-0.185^{\star *}$ & $-0.207^{*}$ & -0.17 & 85 & 0.73 \\
\hline PHL & $0.249^{\star *}$ & $0.594^{\star * *}$ & 0.0425 & 0.89 & 118 & 0.50 \\
\hline POL & $0.631^{* * *}$ & 0.0674 & 0.213 & 0.91 & 121 & 0.67 \\
\hline ROU & $0.561^{* * *}$ & 0.0173 & $-0.200^{\star \star \star}$ & 0.38 & 84 & 0.73 \\
\hline RUS & $0.682^{\star * *}$ & 0.0392 & 0.0579 & 0.78 & 188 & 0.79 \\
\hline SVK & $0.445^{\star}$ & 0.119 & $0.329^{* *}$ & 0.89 & 55 & 0.59 \\
\hline SVN & $0.424^{\star \star *}$ & 0.00827 & -0.2 & 0.23 & 62 & 0.82 \\
\hline THA & $0.361^{* * *}$ & $0.143^{*}$ & 0.00402 & 0.51 & 94 & 0.73 \\
\hline TUR & $0.599^{\star \star *}$ & $0.105^{\star *}$ & 0.000972 & 0.70 & 145 & 0.89 \\
\hline ZAF & $0.696^{* * *}$ & $0.0702^{* *}$ & 0.00586 & 0.77 & 64 & 0.86 \\
\hline
\end{tabular}

Note: Price of labour price is measured as labour expenses divided by the number of employees 
Table A.7. H-statistic, proxy 2 for price of labour and control variables, hypothesis testing

\begin{tabular}{|l|cc|}
\hline Country & $\begin{array}{c}\text { p-value perfect cartel } \\
(\%)\end{array}$ & $\begin{array}{c}\text { p-value perfect competition } \\
(\%)\end{array}$ \\
\hline ARG & 0.0 & 60.8 \\
BGR & 1.2 & 92.5 \\
BRA & 0.0 & 1.0 \\
CHL & 0.0 & 8.2 \\
CZR & 0.2 & 2.9 \\
HUN & 0.0 & 1.3 \\
IDN & 0.3 & 21.8 \\
IND & 0.0 & 1.1 \\
ISR & 0.0 & 0.0 \\
KOR & 54.4 & 0.0 \\
LTU & 0.0 & 7.4 \\
MYS & 0.3 & 0.1 \\
PER & 0.0 & 0.1 \\
PHL & 92.6 & 0.0 \\
POL & 0.1 & 66.7 \\
ROU & 0.1 & 71.5 \\
RUS & 0.1 & 0.0 \\
SVK & 0.0 & 0.9 \\
SVN & 0.0 & 51.2 \\
THA & 6.9 & 0.0 \\
TUR & 0.1 & 0.3 \\
ZAF & 0.0 & 0.0 \\
\hline
\end{tabular}

Perfect competition: (1) $\mathrm{H} 0: \mathrm{H}=1, \mathrm{H} 1: \mathrm{H} \neq 1$; perfect cartel (2) $\mathrm{H} \leq 0, \mathrm{H} 1: \mathrm{H}>0$

Figure A.1 H-statistic, estimation without control variables

A. Proxy 1 for price of labour

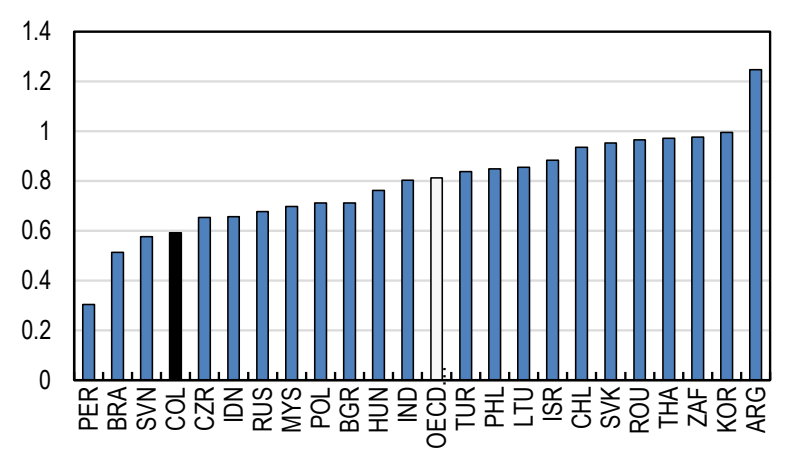

B. Proxy 2 for price of labour

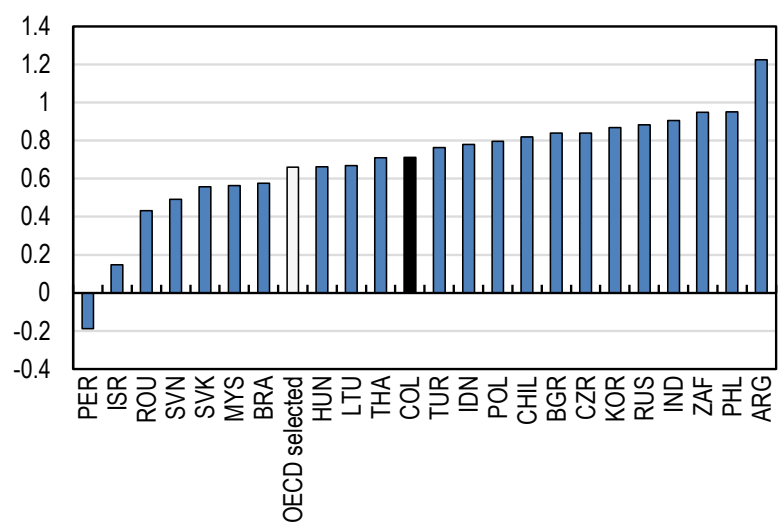

Note: proxy 1 for price of labour = labour expenses/total assets, proxy 2 for price of labour = labour expenses/number of employees. Source: raw data Bloomberg and SNL Financial. 
Table A.8. H-statistic, proxy 1 for labour price without control variables

\begin{tabular}{|c|c|c|c|c|c|c|}
\hline Country & Price of Funds & Price of Equipment & Price of Labour & $\mathbf{H}$ & Observations & R-squared \\
\hline ARG & $0.737^{* \star \star}$ & 0.0205 & $0.490^{* * *}$ & 1.25 & 101 & 0.83 \\
\hline BGR & $0.379^{* *}$ & -0.0145 & 0.348 & 0.71 & 85 & 0.38 \\
\hline BRA & $0.488^{* * *}$ & -0.0578 & 0.0824 & 0.51 & 255 & 0.41 \\
\hline CHL & $0.525^{\star \star \star}$ & 0.068 & $0.343^{* * *}$ & 0.94 & 92 & 0.86 \\
\hline COL & $0.545^{\star \star \star}$ & 0.0425 & 0.00405 & 0.59 & 88 & 0.59 \\
\hline CZR & $0.436^{\star \star \star}$ & -0.0992 & 0.317 & 0.65 & 77 & 0.69 \\
\hline HUN & $0.567^{* \star \star}$ & $0.0418^{*}$ & $0.153^{\star *}$ & 0.76 & 61 & 0.79 \\
\hline IDN & $0.372^{\star \star \star}$ & 0.00234 & $0.282^{* * *}$ & 0.66 & 388 & 0.32 \\
\hline IND & $0.830^{\star \star \star}$ & -0.0304 & 0.00387 & 0.80 & 397 & 0.83 \\
\hline ISR & $0.346^{* * *}$ & 0.0711 & 0.466 & 0.88 & 80 & 0.72 \\
\hline KOR & $0.730^{\star \star *}$ & $0.0712^{* *}$ & $0.195^{\star * *}$ & 1.00 & 151 & 0.97 \\
\hline LTU & $0.516^{\star \star \star}$ & -0.0639 & $0.403^{* *}$ & 0.86 & 43 & 0.90 \\
\hline MYS & $0.543^{* \star *}$ & $0.109^{* * *}$ & 0.0464 & 0.70 & 259 & 0.75 \\
\hline PER & $0.376^{* * *}$ & 0.00151 & -0.0732 & 0.30 & 121 & 0.41 \\
\hline PHL & $0.222^{* * *}$ & $0.253^{* *}$ & $0.374^{\star * *}$ & 0.85 & 170 & 0.43 \\
\hline POL & $0.720^{\star \star \star}$ & -0.0541 & 0.0461 & 0.71 & 143 & 0.66 \\
\hline ROU & $0.575^{\star \star *}$ & -0.0493 & $0.440^{*}$ & 0.97 & 86 & 0.70 \\
\hline RUS & $0.426^{\star \star \star}$ & $0.0748^{*}$ & $0.177^{* *}$ & 0.68 & 294 & 0.64 \\
\hline SVK & $0.402^{\star *}$ & -0.197 & $0.748^{\star * *}$ & 0.95 & 55 & 0.56 \\
\hline SVN & $0.563^{* * *}$ & $-0.158^{\star *}$ & $0.172^{*}$ & 0.58 & 62 & 0.76 \\
\hline THA & $0.414^{\star \star \star}$ & $0.108^{\star *}$ & $0.450^{* * *}$ & 0.97 & 146 & 0.81 \\
\hline TUR & $0.601^{* \star *}$ & 0.0356 & $0.202^{\star *}$ & 0.84 & 179 & 0.82 \\
\hline ZAF & $0.576^{\star \star \star}$ & $0.330^{*}$ & $0.0703^{*}$ & 0.98 & 74 & 0.64 \\
\hline
\end{tabular}

Note: Price of labour price is measured as labour expenses divided by the total assets 
Table A.9. H-Statistic, proxy 2 for labour price without control variables

\begin{tabular}{|c|c|c|c|c|c|c|}
\hline Country & Price of Funds & Price of Equipment & Price of Labour & H & Observations & R-squared \\
\hline ARG & $0.526^{\star \star *}$ & $0.392^{* \star *}$ & $0.306^{* \star *}$ & 1.22 & 59 & 0.94 \\
\hline BGR & 0.335 & $0.210^{* *}$ & 0.294 & 0.84 & 75 & 0.23 \\
\hline BRA & $0.496^{\star \star \star}$ & -0.0176 & 0.0977 & 0.58 & 155 & 0.46 \\
\hline CHL & $0.471^{* \star *}$ & $0.271^{* * *}$ & $0.0775^{* *}$ & 0.82 & 62 & 0.91 \\
\hline COL & $0.595^{\star * *}$ & 0.0322 & 0.0853 & 0.71 & 79 & 0.77 \\
\hline CZR & $0.377^{\star * *}$ & 0.108 & $0.355^{\star \star *}$ & 0.84 & 73 & 0.77 \\
\hline HUN & $0.546^{\star * *}$ & $0.0522^{* *}$ & 0.064 & 0.66 & 59 & 0.76 \\
\hline IDN & $0.470^{\star \star *}$ & $0.116^{*}$ & $0.193^{* \star *}$ & 0.78 & 376 & 0.33 \\
\hline IND & $0.804^{\star \star *}$ & 0.00303 & $0.0973^{\star * *}$ & 0.90 & 316 & 0.85 \\
\hline ISR & $0.338^{\star \star \star}$ & $0.214^{* *}$ & $-0.405^{\star * *}$ & 0.15 & 75 & 0.75 \\
\hline KOR & $0.670^{\star \star *}$ & $0.120^{* *}$ & 0.0787 & 0.87 & 125 & 0.93 \\
\hline LTU & $0.537^{\star \star \star}$ & 0.101 & 0.0309 & 0.67 & 40 & 0.85 \\
\hline MYS & $0.517^{* \star *}$ & $0.0782^{* *}$ & -0.0323 & 0.56 & 106 & 0.79 \\
\hline PER & $0.312^{\star \star *}$ & -0.204 & $-0.296^{\star *}$ & -0.19 & 85 & 0.46 \\
\hline PHL & $0.211^{*}$ & $0.709^{* \star *}$ & 0.0303 & 0.95 & 118 & 0.42 \\
\hline POL & $0.688^{\star \star *}$ & 0.0069 & 0.101 & 0.80 & 121 & 0.61 \\
\hline ROU & $0.726^{* * *}$ & -0.00549 & $-0.288^{\star \star \star}$ & 0.43 & 84 & 0.64 \\
\hline RUS & $0.765^{\star \star *}$ & $0.0625^{\star *}$ & 0.056 & 0.88 & 188 & 0.69 \\
\hline SVK & $0.373^{\star *}$ & 0.054 & $0.130^{*}$ & 0.56 & 55 & 0.47 \\
\hline SVN & $0.575^{\star \star \star}$ & -0.0954 & 0.0121 & 0.49 & 62 & 0.75 \\
\hline THA & $0.351^{* * *}$ & $0.172^{\star *}$ & $0.186^{*}$ & 0.71 & 94 & 0.66 \\
\hline TUR & $0.682^{* * *}$ & $0.0615^{*}$ & 0.02 & 0.76 & 145 & 0.81 \\
\hline ZAF & $0.541^{* * *}$ & $0.358^{*}$ & 0.0484 & 0.95 & 64 & 0.62 \\
\hline
\end{tabular}

Note: Price of labour price is measured as labour expenses divided by the number of employees

Table A.10. H-Statistic for two sub periods in Colombia

\begin{tabular}{|c|c|c|}
\hline Price of bank output & 2004-2008 & 2009-2013 \\
\hline Log(price funds) & $\begin{array}{l}0.731^{\star \star \star} \\
(-0.0462)\end{array}$ & $\begin{array}{l}0.640^{\star \star \star} \\
(-0.126)\end{array}$ \\
\hline Log(price equipment) & $\begin{array}{l}-0.0683 \\
(-0.0754)\end{array}$ & $\begin{array}{l}-0.125 \\
(-0.313)\end{array}$ \\
\hline Log(price labour) & $\begin{array}{l}0.301^{\star \star *} \\
(-0.0926)\end{array}$ & $\begin{array}{l}0.152^{*} \\
(-0.0784)\end{array}$ \\
\hline Loans/deposits & $\begin{array}{l}0.729^{* * *} \\
(-0.0931)\end{array}$ & $\begin{array}{l}-0.000665^{\star * *} \\
(-0.000133)\end{array}$ \\
\hline Equity/assets & $\begin{array}{l}0.153 \\
(-0.891)\end{array}$ & $\begin{array}{l}-0.200 \\
(-0.746)\end{array}$ \\
\hline Earning assets/total assets & $\begin{array}{l}-0.281^{*} \\
(-0.149)\end{array}$ & $\begin{array}{l}-0.123 \\
(-0.599)\end{array}$ \\
\hline H-statistic & 0.963 & 0.667 \\
\hline Number of observations & 98 & 106 \\
\hline R-squared & 0.843 & 0.625 \\
\hline
\end{tabular}


Table A.11. Parametric approach for a time-varying H-statistic in Colombia

\begin{tabular}{|c|l|}
\hline Price of bank output & Estimates \\
\hline$\alpha$ & 0.795 \\
& $(-1.91)$ \\
$\boldsymbol{\tau}$ & -0.013 \\
& $(7.01)^{\star *}$ \\
$\boldsymbol{\beta}_{\mathbf{1}}$ & 0.736 \\
& $(9.50)^{\star *}$ \\
$\boldsymbol{\beta}_{\mathbf{2}}$ & 0.47 \\
& $(5.30)^{\star *}$ \\
$\boldsymbol{\beta}_{\mathbf{3}}$ & 0.165 \\
& $(-1.95)$ \\
$\boldsymbol{\theta}_{\mathbf{1}}$ & 0 \\
& $(-0.54)$ \\
$\boldsymbol{\theta}_{\mathbf{2}}$ & -1.309 \\
& $(3.98)^{\star *}$ \\
$\boldsymbol{\theta}_{\mathbf{3}}$ & 1.432 \\
& $(3.86)^{\star *}$ \\
Number of observations & 204 \\
R-squared & 0.59 \\
\hline \multicolumn{2}{|c}{${ }^{*} p<0.05 ;{ }^{* *} p<0.01$} \\
\hline
\end{tabular}

Note: Estimates of the non-linear least squares equation $\ln \left(p_{i t}^{y}\right)=\alpha+\exp (\tau \times \operatorname{time})\left(\sum_{j=1}^{3} \beta_{j} \ln \left(p_{i t}^{j}\right)\right)+\sum_{j} \theta_{j} B S F_{i t}+v_{i}$ in Colombia for $2004-2013$.

\section{Further insights on public/foreign ownership}

76. This section investigates more in detail the impact of ownership on banks' performance, as well as testing the robustness of the efficiency levels previously measured. The analysis in section 2 focused on system-wide spill-over effects induced by public and/or foreign banks. An increase in the percentage of government-held banks was found to have a negative impact on other banks' efficiency, while no significant effect of variations in the share of foreign banks was identified. However the direct effect of public/foreign ownership on the bank's own performance was not explored. Using a different sample of banks and including information on individual ownership, the present section explores these direct effects.

\section{Description of the sample}

77. A sample covering 21 countries $^{10}$ for the period 1999 - 2009 was constituted using raw data from the Bankscope database on an unconsolidated basis ${ }^{11}$. A dummy variable taking the value one if more than 50 percent of the shares are held by foreigners was constituted using the database on bank ownership by Claessens and Van Horen (2013) which covers the 1999 - 2009 period. ${ }^{12}$ Similarly, a dummy variable taking the value one if more than 50 percent of the shares were held by a public institutions was created

10. This sample includes the same countries as previously, excepted for Korea and Chile for which the number of observations was too limited.

11. That is, financial statements do not integrate possible subsidiaries of the concerned banks. The combination $\{\mathrm{U} 1, \mathrm{U} 2, \mathrm{C} 1\}$ of Bankscope consolidation codes was chosen.

12. Information on 79 banks ranked in the national top 20 in terms of assets were added manually by using several sources (consultation of financial statements, banks' websites, SNL Financial) 
using Bankscope data on ownership ${ }^{13}$. To improve data quality, outliers were excluded: banks with negative or zeros deposits, assets, equity, funding and earning assets or expenses were dropped from the sample. After data filtering the sample is comprised of 4521 (see Table A.12).

Table A.12. Number of observations by year and country

\begin{tabular}{|lllllllllllll|}
\hline Country & $\mathbf{1 9 9 9}$ & $\mathbf{2 0 0 0}$ & $\mathbf{2 0 0 1}$ & $\mathbf{2 0 0 2}$ & $\mathbf{2 0 0 3}$ & $\mathbf{2 0 0 4}$ & $\mathbf{2 0 0 5}$ & $\mathbf{2 0 0 6}$ & $\mathbf{2 0 0 7}$ & $\mathbf{2 0 0 8}$ & $\mathbf{2 0 0 9}$ & Total \\
\hline ARG & 48 & 49 & 48 & 49 & 49 & 49 & 49 & 50 & 51 & 54 & 55 & $\mathbf{5 5 1}$ \\
\hline BGR & 9 & 12 & 12 & 12 & 11 & 11 & 13 & 14 & 16 & 16 & 17 & $\mathbf{1 4 3}$ \\
\hline BRA & 55 & 58 & 63 & 63 & 64 & 61 & 58 & 62 & 72 & 72 & 68 & $\mathbf{6 9 6}$ \\
\hline COL & 13 & 13 & 14 & 14 & 14 & 14 & 14 & 15 & 15 & 18 & 19 & $\mathbf{1 6 3}$ \\
\hline CZE & 6 & 7 & 5 & 7 & 7 & 10 & 10 & 15 & 16 & 15 & 19 & $\mathbf{1 1 7}$ \\
\hline HUN & 2 & 2 & 2 & 2 & 2 & 2 & 3 & 3 & 3 & 3 & 3 & $\mathbf{2 7}$ \\
\hline IDN & 25 & 26 & 24 & 25 & 31 & 30 & 33 & 35 & 37 & 37 & 39 & $\mathbf{3 4 2}$ \\
\hline IND & 4 & 5 & 37 & 45 & 51 & 51 & 50 & 55 & 54 & 56 & 56 & $\mathbf{4 6 4}$ \\
\hline ISR & 7 & 6 & 7 & 7 & 6 & 6 & 6 & 6 & 6 & 6 & 6 & $\mathbf{6 9}$ \\
\hline LTU & 6 & 7 & 7 & 8 & 8 & 8 & 7 & 8 & 8 & 7 & 8 & $\mathbf{8 2}$ \\
\hline MYS & & & & 1 & 1 & 2 & 3 & 3 & 2 & 2 & 2 & $\mathbf{1 6}$ \\
\hline PER & 9 & 10 & 10 & 10 & 10 & 11 & 11 & 12 & 12 & 14 & 15 & $\mathbf{1 2 4}$ \\
\hline PHL & & & & & 1 & 8 & 28 & 29 & 23 & 25 & 29 & $\mathbf{1 4 3}$ \\
\hline POL & & & & & & 6 & 9 & 12 & 14 & 19 & 23 & $\mathbf{8 3}$ \\
\hline ROM & 7 & 11 & 11 & 9 & 12 & 11 & 13 & 14 & 15 & 14 & 16 & $\mathbf{1 3 3}$ \\
\hline RUS & 18 & 35 & 49 & 45 & 49 & 90 & 113 & 127 & 127 & 132 & 130 & $\mathbf{9 1 5}$ \\
\hline SVK & 2 & 1 & 1 & 1 & 2 & 2 & 7 & 8 & 9 & 8 & 8 & $\mathbf{4 9}$ \\
\hline SVN & 6 & 6 & 5 & 5 & 5 & 4 & 9 & 11 & 11 & 14 & 17 & $\mathbf{9 3}$ \\
\hline THA & 13 & 13 & 13 & 14 & 14 & 15 & 18 & 18 & 20 & 21 & 21 & $\mathbf{1 8 0}$ \\
\hline TUR & & & 1 & 1 & 2 & 2 & 1 & 12 & 17 & 19 & 19 & $\mathbf{7 4}$ \\
\hline ZAF & & & & & & 4 & 7 & 11 & 9 & 14 & 12 & $\mathbf{5 7}$ \\
\hline Total & $\mathbf{2 3 0}$ & $\mathbf{2 6 1}$ & $\mathbf{3 0 9}$ & $\mathbf{3 1 8}$ & $\mathbf{3 3 9}$ & $\mathbf{3 9 7}$ & $\mathbf{4 6 2}$ & $\mathbf{5 2 0}$ & $\mathbf{5 3 7}$ & $\mathbf{5 6 6}$ & $\mathbf{5 8 2}$ & $\mathbf{4 5 2 1}$ \\
\hline & & & & & & & & & & & & \\
\hline
\end{tabular}

\section{Description of the model}

78. Compared to the previous analysis, some slightly different definitions of inputs and outputs are used because of differences in the underlying data. Two inputs are considered: financial $\left(x^{1}\right)$ and nonfinancial inputs $\left(x^{2}\right)^{14}$ - for instance labour, buildings and equipment. The definition of outputs is broaden as it entails three categories of outputs, namely total earning assets $\left(q^{1}\right)$, total customer deposits $\left(q^{2}\right)$, and total non-interest operating income $\left(q^{3}\right)^{15}$. In this setting, banks are not only producing financial goods that are exchangeable on the financial markets captured by $q^{1}$, but also producing services to depositors and other clients which are captured respectively by $q^{2}$ and $q^{3}$. The price of financial input $\left(p^{1}\right)$ is obtained as

13. Since no equivalent of the $\mathrm{CvH}$ database exists for public ownership, an approximation was considered. A bank identified as public in 2014 was classified as public for the period $1999-2009$.

14. Financial input is measured by total interest expenses. Non-financial inputs are measured by total noninterest expenses which is the sum of personnel expenses and other operating expenses

15. Total earning assets include net loans, loans and advances to banks, total securities, insurance assets, investment in property and other earning assets. Total customer deposits include current, savings and terms deposits. Total non-interest operating income includes net gains on trading and derivatives, net gains on other securities, net insurance income, net fees and commissions, and other operating income. 
the ratio of $x^{1}$ to total funding while the price of non-financial input $\left(p^{2}\right)$ is obtained as the ratio of $x^{2}$ to total assets ${ }^{16}$. Total cost (TC) is the sum total interest expenses and non-interest expenses.

79. As previously, the Battese-Coelli 1995 model is used to simultaneously evaluate the efficient frontier, the individual inefficiencies, and the impact of selected variables on inefficiencies. The following Cobb-Douglas ${ }^{17}$ cost function $\left(1^{\prime}\right)$ and inefficiency model $\left(2^{\prime}\right)$, are considered:

$$
\begin{aligned}
\ln \left(T C_{i t}\right)=\beta_{0}+ & \sum_{j=1}^{2} \beta_{j} \ln \left(p_{i t}^{j}\right) \\
& +\beta_{4} \ln \left(q_{i t}^{1}\right)+\beta_{5} \ln \left(q_{i t}^{2}\right)+\beta_{6} \ln \left(\max \left(q_{i t}^{3}, 1-\mathbf{1}\left\{q_{i t}^{3}>0\right\}\right)\right)+\beta_{7} \mathbf{1}\left\{\text { crisis }_{i t}\right\}+\beta_{7} \text { time trend } \\
& +v_{i t}+u_{i t}\left(1^{\prime}\right) \\
u_{i t}= & \delta_{0}+\delta_{1} \frac{E_{i t}}{A_{i t}}+\delta_{2} \frac{L_{i t}}{\mathrm{D}_{i t}}+\delta_{3} \frac{R N P L s_{i t}}{L_{i t}} \\
& +\delta_{4} \mathbf{1}\left\{\text { foreign }_{i t}\right\}+\delta_{5} \mathbf{1}\left\{\text { public }_{i t}\right\}+\delta_{6} \text { time trend }+w_{i t}\left(2^{\prime}\right),
\end{aligned}
$$

80. Concerning the frontier model (equation $\left(1^{\prime}\right)$ ), the proxy of services produced $q^{3}$ is a net item, implying that it can be negative (this is the case for 201 observations). To circumvent this issue, one could use an indicator variable $\mathbf{1}\left\{q_{i t}^{3}>0\right\}$ taking the value 1 when $q_{i t}^{3}$ is positive, and zero when it is smaller than 0 (see Battese-Coelli 1992). The frontier model also includes a country specific dummy variable taking the value 1 when a country was impacted by a financial crisis, based on the dataset released by Laeven and Fabián in 2012. A time trend is included to capture the Hicksian neutral technological change.

81. In the inefficiency model (equation $\left(2^{\prime}\right)$ ), a time trend is included to allow for the inefficiency effects to vary linearly with time. Three control variables at the banks level are considered: the ratio of total equity to total assets $\frac{E_{i t}}{A_{i t}}$ and total loans to customers deposits $\frac{\mathrm{L}_{i t}}{\mathrm{D}_{i t}}$ are introduced to capture differences in leveraging an risk preferences; the ratio of reserve for non-performing loans to total gross loans $\frac{R N P L s_{i t}}{L_{i t}}$ capture variations in risk exposure and risk-taking. These three control variables are expressed in percentages. $\mathbf{1}\left\{\right.$ foreign $\left._{i t}\right\}$ and $\mathbf{1}\left\{\right.$ public $\left._{i t}\right\}$ are two dummies variables taking the value 1 if a bank was foreign-held and/or public.

82. As discussed previously, the relation between the inefficiency term $u_{i t}$ and the level of cost efficiency is given by the equation $C E_{i t}=\exp \left(-u_{i t}\right) \cdot v_{i t}$ is assumed to be and independent and identically distributed random error following a normal distribution of zero mean and variance $\sigma_{v}^{2}$. $w_{i t}$ is the truncation of a normal distribution with zero mean and variance $\sigma^{2}$ such that the point of truncation is $-\boldsymbol{z}_{\boldsymbol{i t}} \boldsymbol{\delta}$ with $\boldsymbol{z}_{\boldsymbol{i}}$ the vector of explanatory variables included in (2') and $\boldsymbol{\delta}$ the vector of unknown coefficients to estimate. The likelihood function is expressed in terms of variance parameters $\sigma_{s}^{2}=\sigma_{v}^{2}+$ $\sigma^{2}$ and $\gamma=\sigma^{2} / \sigma_{s}^{2}$.

16. Total funding includes total deposits, money market and short-term funding; total long-term funding and trading liabilities

17. It is common for empirical studies of banks efficiency to rely on a translog cost function. However, the extra-number of parameters causes convergence issues when estimating the model. 
ECO/WKP(2015)21

\section{Results}

Table A.13. Joint estimation of the cost frontier and inefficiency determinants

\begin{tabular}{|c|c|c|c|c|}
\hline & Estimate & Std Error & $z$ value & $\operatorname{Pr}(>|z|)(\%)$ \\
\hline \multicolumn{5}{|l|}{ Stochastic frontier } \\
\hline Intercept & 0.64 & 0.02 & 31.11 & 0.00 \\
\hline $\log (q 1)$ & 0.91 & 0.01 & 172.96 & 0.00 \\
\hline $\log (q 2)$ & 0.08 & 0.00 & 18.99 & 0.00 \\
\hline $\log (q 3)$ & 0.01 & 0.00 & 6.03 & 0.00 \\
\hline $\log (p 1)$ & 0.41 & 0.00 & 90.03 & 0.00 \\
\hline $\log (p 2)$ & 0.58 & 0.00 & 121.11 & 0.00 \\
\hline Time trend & 0.00 & 0.00 & 0.35 & 0.73 \\
\hline Dummy crisis & 0.11 & 0.01 & 13.27 & 0.00 \\
\hline \multicolumn{5}{|l|}{ inefficiency model } \\
\hline Intercept & -87.88 & 17.55 & -5.01 & 0.00 \\
\hline $\mathrm{E} / \mathrm{A}(\%)$ & -14.16 & 3.07 & -4.61 & 0.00 \\
\hline L/D (\%) & 6.68 & 1.31 & 5.09 & 0.00 \\
\hline RNPLs/L (\%) & 34.17 & 7.06 & 4.84 & 0.00 \\
\hline dummy foreign & -12.02 & 2.38 & -5.05 & 0.00 \\
\hline dummy public & 2.39 & 0.48 & 4.93 & 0.00 \\
\hline time trend & -1.42 & 0.29 & -4.95 & 0.00 \\
\hline \multicolumn{5}{|l|}{ variance parameters } \\
\hline$\sigma_{s}^{2}$ & 17.82 & 3.56 & 5.01 & 0.00 \\
\hline$\gamma$ & 1.00 & 0.00 & 8425.87 & 0.00 \\
\hline Log-likelihood value & 963.3371 & & & \\
\hline Number of observation & 4521.00 & & & \\
\hline
\end{tabular}

Figure A.2. Stochastic frontier analysis, commercial banking sectors' average cost efficiency, 1999 - 2009

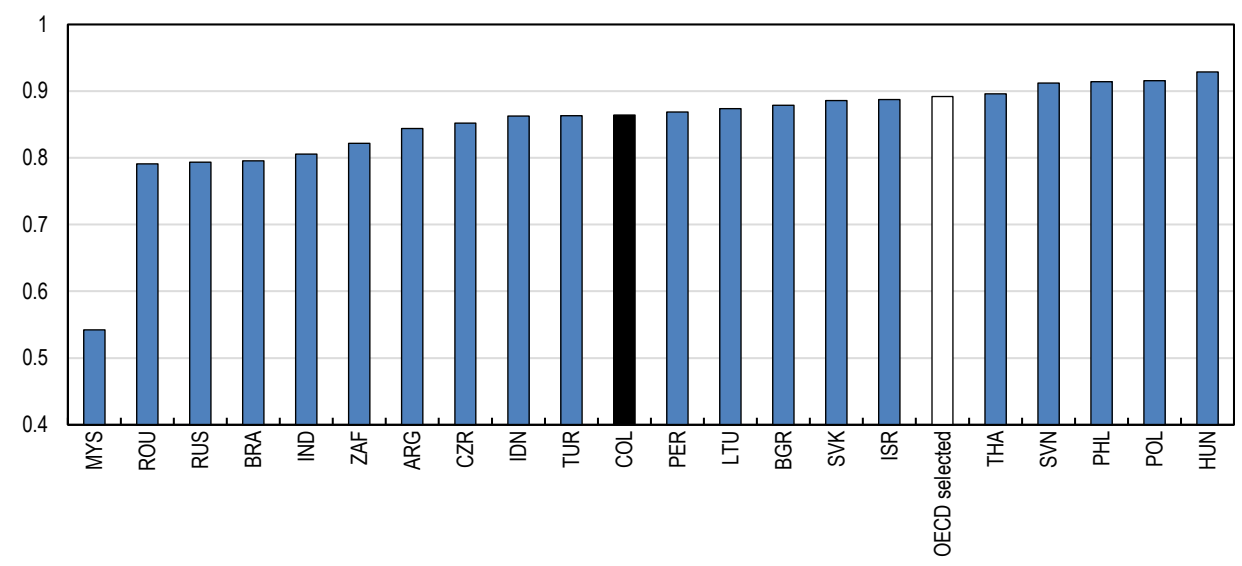

Note: Cost efficiency (CE) is a measure of the relative distance from the efficient frontier. It ranges between 1 and 0 for a fully efficient and a fully inefficient firm respectively. OECD selected countries includes Czech Republic, Hungary, Israel, Poland, Slovakia, Slovenia, and Turkey. Countries' results are obtained as simple average of domestic banks' scores.

Source: Authors' calculation based on data from Bankscope 
83. In this setting and period of study, countries as Peru, Argentina, Philippines and Hungary appear to be more efficient than what was estimated for the period 2003 - 2013 (see Figure 7). Malaysia's efficiency level is poor compared to what was previously estimated. This is probably due to the poor quality available for this country (see Table A.13). However, the general finding that Colombia's banking sector efficiency level is low by OECD standards is confirmed.

84. In the stochastic frontier model, as expected, the elasticities of total cost in input prices and output quantities are positive. The Hicksian neutral technological change is not statistically different from zero, while the dummy variable is positive and strongly significant, indicating that period of crisis are associated with higher cost for banks.

85. In the inefficiency model, contrary to what was presented previously, an increase in the ratio of equity to total assets is associated with a decrease in inefficiency, that is, an increase in efficiency; an increase in the ratio of loans to customers deposits is associated with an increase in inefficiency, that is, a decrease in efficiency. Both results are surprising given that increases in leverage should translate in more earning assets produced for a same level in inputs produced. However, this might reflect the fact that banks that took excessive risks have been the hardest hit during the global financial crisis. On the other hand, the sign of the coefficient associated with reserve for NPLs to total gross seems intuitive: an increase in this ratio is likely when assets and profits are under stress, thus the measured efficiency is negatively impacted. Interestingly, the sign of the dummy variable for public-ownership is positive and the one for foreignownership is negative: public-ownership increases inefficiencies and foreign-ownership decreases inefficiencies.

86. To conclude, the direct effect of foreign ownership is found to be positive. Foreign owners are likely to bring new practices to an existing bank when acquiring it, or because of a self-selection process, more efficient banks are more likely to enter a foreign market. Public ownership is negatively associated with efficiency gains, which could be due to differences in management and a reduced exposure to market forces. However, one limitation of this analysis is that public banks may perform activities that are not necessarily profit driven and that are not captured as outputs in this framework. 
ECO/WKP(2015)21

\section{WORKING PAPERS}

The full series of Economics Department Working Papers can be consulted at www.oecd.org/eco/workingpapers

1202. Fiscal decentralisation in Colombia: New evidence regarding sustainability, risk sharing and "fiscal fatigue"

(April 2015) by Guillaume Bousquet, Christian Daude and Christine de la Maisonneuve

1201. Effects of economic policies on microeconomic stability

(April 2015) by Boris Cournède, Paula Garda and Volker Ziemann

1200. The 2013 update of the OECD's database on product market regulation - policy insights for $O E C D$ and non-OECD countries

(April 2015) by Isabell Koske, Isabelle Wanner, Rosamaria Bitetti and Omar Barbiero

1199. Improving taxes and transfers in Australia

(April 2015) by Philip Hemmings and Annamaria Tuske

1198. Federal-state relations in Australia

(April 2015) by Vassiliki Koutsogeorgopoulou and Annamaria Tuske

1197. Sharing the fruits of growth with all Mexicans

(April 2015) by Eduardo Olaberriá and Valéry Dugain

1196. What makes Mexicans happy?

(April 2015) by Valéry Dugain and Eduardo Olaberriá

1195. Improving the labour market integration of immigrants in Belgium

(March 2015) by Álvaro Pina, Vincent Corluy and Gerlinde Verbist

1194. Raising the potential of the domestically oriented sector in Germany

(March 2015) by André Eid and Andrés Hutfilter

1193. Improving transport infrastructure in Russia

(March 2015) by Alexander Kolik, Artur Radziwill and Natalia Turdyeva

1192. Improving the business climate in Russia

(March 2015) by Arthur Radziwill and Yana Vaziakova

1191. Determinants of female entrepreneurship in India

(March 2015) by Arnaud Daymard

1190. The changing role of the exchange rate for macroeconomic adjustment

(March 2015) by Patrice Ollivaud, Elena Rusticelli and Cyrille Schwellnus

1189. Boosting productivity in Russia: skills, education and innovation

(March 2015) by Lilas Demmou and Andreas Wörgötter

1188. Boosting growth and reducing informality in Mexico

(March 2015) by Sean Dougherty 
1187. The conduct of monetary policy in the future: instrument use

(March 2015) by Kei-Ichiro Inaba, Rory O'Farrell, Łukasz Rawdanowicz and Ane Kathrine Christensen

1186. A constant market share analysis of Spanish goods

(February 2015) by Alberto Gonzalez Pandiella

1185. Raising the economic participation of women in India - a new growth engine?

(February 2015) by Piritta Sorsa

1184. Improving health outcomes and health care in India

(January 2015) by Isabelle Joumard and Ankit Kumar

1183. Challenges and opportunities of India's manufacturing sector

(January 2015) by Isabelle Joumard, Urban Sila and Hermes Morgavi

1182. The heterogeneity of product market regulations

(December 2014) by Jean-Marc Fournier

1181. Implicit regulatory barriers in the EU single market: new empirical evidence from gravity models

(December 2014) by Jean-Marc Fournier, Aurore Domps, Yaëlle Gorin, Xavier Guillet and Délia Morchoisne

1180. Can pro-growth policies lift all boats? An analysis based on household disposable income (December 2014) by Orsetta Causa, Alain de Serres and Nicolas Ruiz

1179. Empirical evidence on the effects of environmental policy stringency on productivity growth (December 2014) by Silvia Albrizio, Tomasz Koźluk and Vera Zipperer

1178. The Indicators of the Economic Burdens of Environmental Policy Design - Results from the OECD Questionnaire

(December 2014) by Tomasz Koźluk

1177. Measuring Environmental Policy Stringency in OECD Countries-A Composite Index Approach (December 2014) by Enrico Botta and Tomasz Koźluk

1176. Do Environmental Policies Matter for Productivity Growth? Insights from new Cross-Country Measures of Environmental Policies

(December 2014) by Silvia Albrizio, Enrico Botta, Tomasz Koźluk and Vera Zipperer

1175. Making economic growth more socially inclusive

(December 2014) by Andrés Fuentes Hutfilter and Andreas Kappeler

1174. New tax and expenditure elasticity estimates for EU budget surveillance

(December 2014) by Robert W.R. Price, Thai-Thanh Dang and Yvan Guillemette

1173. Moving towards a more dynamic business sector in Spain

(November 2014) by Alberto Gonzalez Pandiella 